

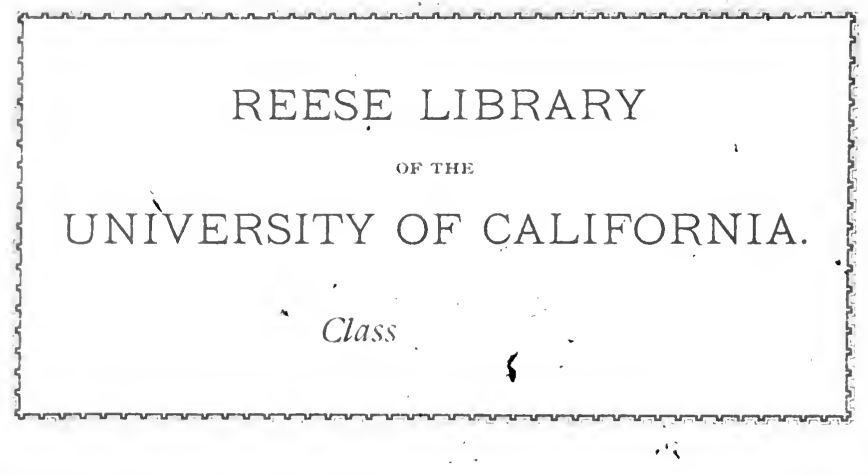


$!$ 
Digitized by the Internet Archive in 2007 with funding from

Microsoft Corporation 


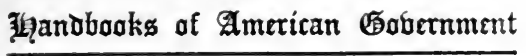

EDITED BY

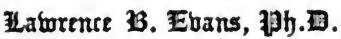

PROFESSOR OF HISTORY IN TUTTS COLLEGK

\section{The Government of Minnesota}


-The> 
○ 


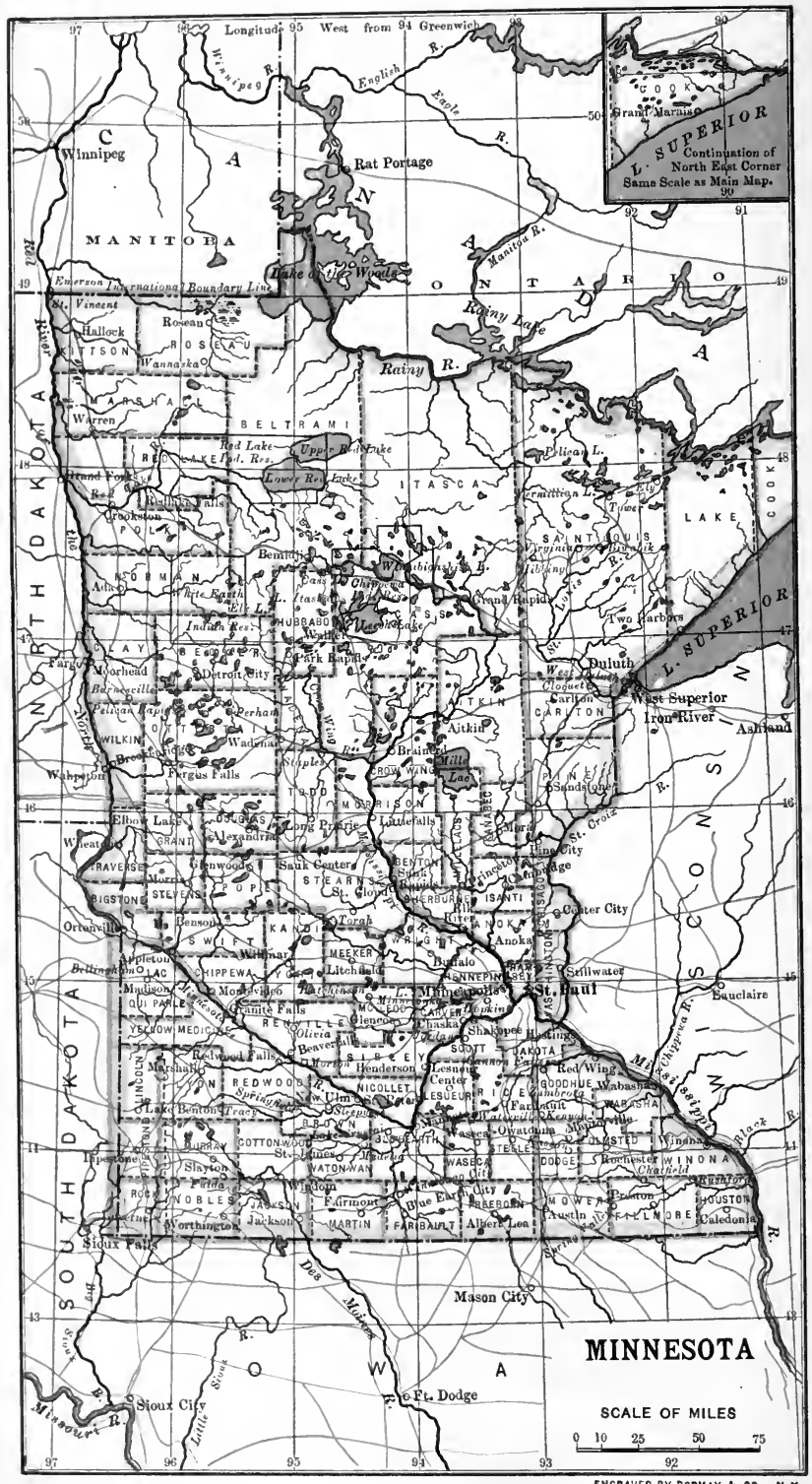


HANDBOOKS OF AMERICAN GOVERNMENT

\section{The}

\section{Government of Minnesota}

\section{Its History and Administration}

BY

FRANK L. MCVEY, PH.D.

PROFESSOR OF ECONOMICS IN THE UNIVERSITY OF MINNESOTA

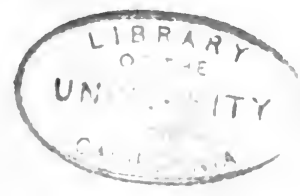

New Mark

THE MACMILLAN COMPANY

LONDON : MACMILLAN \& CO., LTD.

Igor

All rigkts reserved 


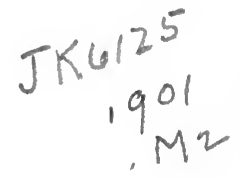

\section{RT SE}

Copyright, rgor,

By THE MACMILLAN COMPANY. 
$\mathbb{C}_{\mathfrak{o}}$

A. H. M. 


\section{PREFACE}

IT has been the purpose of the author to present in a small volume a harmonious picture of the history and government of the commonwealth of Minnesota. There is a pressing and crying need for good teaching in civil government, a subject which has been and is largely neglected in our public schools. To facilitate such teaching carefully prepared books are necessary. This volume is an attempt thoroughly to analyze the functions of a State government, and in addition to open the way to teacher and pupil to the sources of information. At the foot of many pages are numerous references, while at the end of the book is an appendix containing historical material for more extensive work than the text affords. With such aid the teacher can go back of text-book statement into the spirit of our commonwealth's institutions.

The effort in Chapters I and II is to place the history of the State before the student; following these chapters are two others on the general machinery of the government. The remainder of the book is devoted to the actual workings of the machinery. It is to be remembered that legislation changes from time to time the details of government; particularly was this true at the meeting of the legislature of 1899 , which altered the school system and the national vii 
guard, established the primary election law in one county, and changed the city charter act. To keep in touch with such legislation is a part of the work of the teacher. The book as now constituted contains all modifications of the statutes up to I900. The changes in the future will not alter the frame or general features of the government, but may make many alterations in the details of the machinery.

In the preparation of the volume the author has been materially aided by the suggestions of the editor of the series, Professor Lawrence B. Evans of Tufts College, and by Professor William W. Folwell of the University of Minnesota.

F. L. M.

Minneapolis, December, Igo0. 


\title{
CONTENTS
}

\author{
CHAPTER I \\ Minnesota AS A TERRITORY
}

§1. References. §2. Physical Territory. § 3. Explorers. $\S 4$. Settlements. $\$ 5$. The Organization of Minnesota Ter-

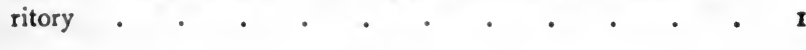

PAGL

CHAPTER II

Minnesota as a State

§6. References. § 7. The Enabling Act. § 8. The Constitutional Convention. \$9. Organization of the Government. \$10. Minnesota in the Civil War. \$11. The Sioux Massacre. \$12. The Building of Railroads. \$13. The Growth of the State. $\$ 14$. Chronological Arrangement of the History of Minnesota

\section{CHAPTER III}

\section{Organization of the State}

§ 15. References. § 16. Restricted Powers of the State. § 17. The Constitution, Preamble, and Bill of Rights. $\$ 18$. Amendment and Revision of the Constitution. $\S 19$. Administrative Divisions

\section{CHAPTER IV}

\section{The Central Government}

\$20. References. §21. The Executive. § 22. Other Elective Officers. \$23. Appointive Officers. \$24. Commissions and Boards. $\$ 25$. The Legislature. $\$ 26$. The Judiciary . . 


\section{CHAPTER V}

\section{LoCAl Government}

§ 27. References. $\S 28$. The County. $\S 29$. The Township. $\S 3$. The Village. § 31. Cities. §32. Minneapolis. §33. St. Paul. § 34. Duluth

\section{CHAPTER VI}

\section{Nominations AND Elections}

§35. References. § 36. Who are Voters? § 37. Nomination of Candidates. $\S 38$. The Corrupt Practices Act. $\S 39$. Machinery of Elections. $\S 40$. The Conduct of Elections. § 41. Canvassing Boards

\section{CHAPTER VII}

\section{The Administration of Justice}

§ 42. References. § 43. The Judicial Power. § 44. The Local and District Courts. $\S 45$. The Supreme Court. $\S 46$. Civil Procedure. $\$ 47$. Criminal Procedure . . . . . 109

\section{CHAPTER VIII}

\section{Revenue AND EXPENDiture}

§ 48. References. § 49. Receipts and Expenses. § 50. The Kinds of Taxes. $\S 5$ I. The Assessment of Property. $\S 52$. The Levying and Collection of Taxes. $\S 53$. The Expenditure of Public Money . . . . . .

\section{CHAPTER IX}

\section{EDUCATION}

§54. References. §55. The Growth of the School System. $\S 56$. The Organization of the School System. \$ 57. The Sup- 
port of the Schools. $\S 58$. Administration of the School System. §59. Normal Schools. §60. The University. §61. Farmers' Institutes, Free Text-books, and Libraries

\section{CHAPTER $\mathrm{X}$}

\section{The Protection of the State}

§62. References. §63. The Problems. § 64. Charitable Institutions. $\$ 65$. Correctional Institutions. $\S 66$. The Board of Charities and Corrections. $\$ 67$. The Militia. $\$ 68$. The Naval Reserves . . . . . . . . 158

\section{APPENDIX}

A. The Governors of Minnesota . . . . . . 173

B. Members of the First Legislature of Minnesota . . $\quad$ - 174

C. Population of Minnesota in 1849. . . . . . 175

D. Growth of Population in Minnesota . . . . 176

E. Nativity of the Population of Minnesota . . . . 180

F. Growth of Cities in Minnesota from 1890 to 1895 . $\quad$. 184

G. An Act to establish the Territorial Government of Minnesota 186

H. The Enabling Act of Minnesota . . . . . 196

I. An Act for the Admission of Minnesota into the Union $\quad 200$

J. Parts of the Constitution of Minnesota. . . . 202

K. Presidential Vote of Minnesota . • . . • 223

L. State Officers of Minnesota . . . . . . . 224

M. County Officers of Minnesota . . . . . 226

N. Town Officers of Minnesota . . . . . . . 227

O. Village Officers of Minnesota $\quad$. $\quad . \quad$. $\quad$. $\quad 228$

P. City Officers of Minnesota . . . . . . . . $\quad$. 229

Q. References to Minnesota in Congressional Documents . $\quad 230$

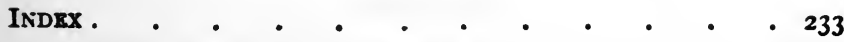





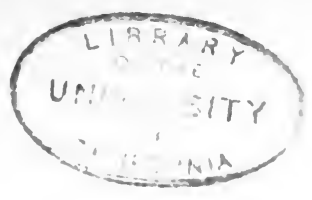

\title{
GOVERNMENT OF MINNESOTA
}

\author{
CHAPTER I \\ MINNESOTA AS A TERRITORY
}

\section{References}

Stevens, Personal Recollections of Minnesota and its People, Minneapolis, 1890; Charlotte Ouisconsin Van Cleve, Three Score Years and Ten, Minneapolis, 1888; West, Ancestry, Life, and Times of $H . H$. Sibley, St. Paul, 1889; Neill, History of Minnesota, St. Paul, 1890; The Publications of the Minnesota Historical Society; some of the articles are particularly important and will be referred to specifically; Journals of the Council and House of Representatives of the First Session of the Legislative Assembly of the Territory of Minnesota, 1849; Williams, History of St. Paul, St. Paul, 1876; Keating, Narrative of an Expedition to the Source of St. Peter's River, London, 1825 ; articles on Minnesota in Johnson's Cyclopadia and Encyclopadia Britannica. A description of the territory may be found in the introduction of Neill, History of Minnesota, and in The Report of the Geological Survey of Minnesota, I, a set of which is deposited in the office of each county auditor.

There is the series of pamphlets on Minnesota History, written and edited by Dr. E. D. Neill, under the title of Macalester College Contributions. Among these are many sketches and much valuable material relating to the early history of the State. The following are useful: The Beginning of Organized Society in the Saint Croix Valley, 1890, No. 3; The Development of Trade on Lake Superior, No. 4; Sieur La Ronde, the First Navigator of Lake Superior, No. 7 ; Pierre Paul, the Commandant at Lake Pepin, 1750-1752, No. 9; A Memoir of the Sioux, No. 10; Memoir of William T. Boutwell, S. S., No. I; The Critical Period of the French Traders on Lakes Michigan and Superior, 1684, S.S., No. 7 ; A Memorial of the Brothers Pond, S. S., No. 8. 


\section{Minnesota as a Territory}

\section{The Physical Territory}

In the exact centre of North America lies the wonderful region known as Minnesota. The State by that name extends four hundred miles from north to south, while the traveller journeys the third of a thousand miles in crossing it from east to west. ${ }^{1}$

Land and water.

Character of surface.

\section{Mineral} wealth. Within this empire-like land are nearly eighty-five thousand square miles of territory. This, translated into acres, carries the figures into the fifty millions; but so numerous are the lakes, numbering about ten thousand, that a seventeenth part of the territory is water. The general character of the surface is that of a high, rolling prairie, ranging, on the average, twelve hundred feet above the sea level, but the highest point is more than a thousand feet above this. $^{2}$ Streams and lakes found in all parts of the State are heavily wooded with every species of timber known on the upper Mississippi, except the beech and sycamore. At one time the northern part of the State was covered by a dense forest of pine, tamarack, spruce, birch, and cedar, but it is now rapidly disappearing under the vigorous attacks of the lumber companies. Fertile indeed is the soil and particularly adapted to the growing of wheat, corn, oats, and barley; the small fruits and vegetables flourish in great abundance.

The last few years have brought to the attention of the world the iron wealth of Minnesota, stored in the Mesabi and Vermillion ranges. ${ }^{3}$ It is in an

${ }^{1} 354$ miles wide. The State lies within the parallels $43^{\circ} 30^{\prime}$ and $49^{\circ}$ north latitude, and the meridians $89^{\circ} 39^{\prime}$ and $97^{\circ} 5^{\prime}$ west longitude.

${ }^{2}$ Minnesota Historical Society's Publications, I. 37.

8 The output in 1899 was $7,000,000$ tons. 
ancient archæan axis traversing the centre of the State from northeast to southwest, that the iron mines are located. ${ }^{1}$ The ore is a soft hematite, very rich and free from impurities, and so perfectly adapted to the making of Bessemer steel that it is sought eagerly by manufacturers. In addition to this great mineral wealth are sands useful in glass making, building stone of many varieties, clay for the potter, and, in the Rainy Lake region, gold in limited quantities. Minnesota, with its natural resources and splendid territory, is a richly endowed commonwealth. With the first historian of the State, we can say: "Minnesota is the birthplace of many rivers, flowing north, south, east, and west; with varied scenery, the prairie, the forest, the lofty bluff, the placid lake, and the laughing waterfall; the summit of the central valley of North America; with an atmosphere peculiarly dry and bracing, it must ever be attractive to emigrants from all regions of the The heritage of Minnesota. world. If the aims of her citizens only correspond with the elevated natural position and advantages, the cattle upon a thousand hills will soon occupy the old pasture grounds of the elk and bison, and schoolhouses will crown the eminences but lately adorned with burial scaffolds; and the State will become the birthplace of not only majestic rivers, but great men." 2

To the people of Minnesota has fallen this heritage, which they have used wisely and well, as the institutions, wealth, and power of her citizens testify. Less than three-quarters of a century ago the main portion of the present State was occupied by the

1 Johnson's Cyclopadia, article “Minnesota."

2 Neill, History of Minnesota, xl. 
Sioux and Chippeway Indians; only a few scattered trading posts then existed, and nothing that could be called a real settlement. In that brief time the original holders of the soil have been dispossessed by purchase, treaty, and warfare, until the whole area, once a wilderness, is dotted by farms, houses, villages, and towns. The Indians in their turn are confined to small reservations, which in time will also be given over to the agriculturist.

Explorers.

\section{EXPLORERS}

Three sets of early explorers travelled over the territory called Minnesota. The French, ambitious and restless, moved westward seeking treasure and adventure; the English, in control only during the short period between the French and Indian War and the Revolution, were too busily engaged elsewhere to pay much attention to what was then the far West. When the Americans therefore acquired the country early in the nineteenth century, the region was little known, and expeditions were sent out under the auspices of the government to explore it.

The French. Nearly seventy years before the English had built Jamestown, the French had a rendezvous in Canada. The explorations of the great lakes went on slowly until the coming of Champlain. This great Frenchman reached Georgian Bay in I643. Twenty-eight years later two Jesuit priests made their way to the Sault Ste. Marie. Glowing accounts were sent to France of the vast trading possibilities and the immense copper deposits in this northwest region. Jean Nicollet, an interpreter of the Canadian Fur Company, 
was the first white man to reach the Green Bay in the north of Wisconsin $;^{1}$ but the first white men to enter Minnesota were Radisson and Grosseillier, in 1659. Not properly encouraged, according to their notion, by the French government, they transferred their allegiance to the English and made other explorations under their flag. René Menard, a Jesuit, reached the Black River, by way of the Mississippi, in $166 \mathrm{I}$, but lost his life in the woods. Allouez in 1665 established a mission at La Pointe, Wisconsin. Thus far all of the explorations had been around the edge of the State. ${ }^{2}$ The governor of Canada, anxious to get more definite information, sent the Sieur Du Lhut, Daniel Graysolon, to the Lake Superior region in $1679 .^{3}$ This explorer went into the State as far as Mille Lac. He was followed by Father Hennepin, a Franciscan monk, who ascended the Mississippi from the Illinois River, and finally reached St. Anthony Falls, the present site of Minneapolis, in I680. Le Sueur, at the opening of the century, explored what is now called the Minnesota River as far as the Blue Earth River. At the junction of the two streams he established a post. With Le Sueur French exploration ceases.

The French were confined in their movements to a strip of territory on the same parallel with Quebec, extending west. This was in reality the line of least resistance. Very few of their explorers were able to get north or south of Minnesota and Lake Superior.

11634. See account in Neill, History of Minnesota, 100. See also whole of ch. iv. in the above history. Minn. Hist. Soc. Pub., I. 183 .

${ }^{2}$ Minn. Hist. Soc. Pub., I. 17. $\quad{ }^{3}$ Ibid., 314. $\quad 4$ Ibid., 319.

Difficulties in the way of the French. 
Charles II. of England had given a charter to the Hudson Bay Company in 1679, granting to it the territory about Hudson Bay, which had been discovered by Radisson and Grosseillier when serving under the English flag. The Treaty of Ryswick in 1697 acknowledged this claim, and from that date the English captured or killed the French traders appearing in the Hudson Bay district. At the south the hostile Iroquois made war upon all Frenchmen. Between these two enemies the French carried on their trade explorations, and this situation accounts for the early entrance of the French into the Minnesota territory.

he English. In the French and Indian War, ending in 1763 , the French lost Canada, and England became the ruler of all the territory in North America east of the Mississippi, with the exception of Louisiana and Florida. Twenty years later the United States won its independence and came into possession of the territory east of the Mississippi and south of Canada. During the period of English possession Jonathan Carver left Boston under the semi-authority of the British government to make explorations in the Northwest. His journey included voyages on the Mississippi from the Wisconsin River to the Elk, and, returning to the mouth of the Minnesota, he ascended that stream as far as the Cottonwood River. An account of the exploration was published in Dublin in $1779 .^{1}$

By the Treaty of 1783 with Great Britain and the mericans. Louisiana purchase in 1803 the United States ac-

${ }^{1}$ Neill, History of Minnesota, 202-221, also Minn. Hist. Soc. Pub., I. 349 . 
quired a great unknown region. The government sent successive expeditions into this territory to gather information and make treaties with the Indian tribes. The first of these was that of Lieutenant Zebulon Pike, who was sent in 1805 to enforce the federal laws, which were disregarded by the English traders after the transfer of the region to the United States. He was also to make treaties with the Indians, and through his efforts the cession of the Fort Snelling military reservation was obtained. ${ }^{1}$ The British and Canadian traders were subdued for a time, but the War of 1812 gave them further opportunity to encourage the hostility of the Indians, and for several years the new territory received but little attention from the government of the United States.

The governor of Michigan, Lewis Cass, was anxious to visit all parts of the land under his jurisdiction. On the 18th of November, 1819, he proposed to the Secretary of War, Mr. Calhoun, the exploration of the recently annexed portion of Michigan, and received permission to undertake it. Governor Cass and his Expeditions. followers entered the State at the head of Lake Superior and proceeded as far south and west as St. Anthony Falls; the expedition was not productive of results. ${ }^{2}$ The government still seeking more definite knowledge, sent, in 1823 , Major Stephen F. Long, an officer who had already made one journey six years before from St. Louis to St. Anthony Falls,

1 This cession included a tract of land at the mouth of the St. Croix, and also a tract beginning below the conflux of the Mississippi and St. Peter's, and extending up the Mississippi to include the Falls of St. Anthony and nine miles on each side of the river.

2 See account in Neill's History of Minnesola, 321. 
to explore Minnesota. The expedition went threequarters around the State by the way of the Minnesota River, Big Stone Lake, Red River, Lake of the Woods, and Rainy Lake to Lake Superior. ${ }^{1}$ Much valuable information was secured through the efforts of Major Long.

Possibly the most famous of the expeditions was the one under the leadership of Schoolcraft. A number of distinguished men accompanied the exploring party, among whom were Dr. Douglass Houghton, botanist and geologist, and the Rev. W. T. Boutwell, a missionary of the American Board of Foreign Missions. $^{2}$ Pipes of peace were smoked with the Indians, councils held, and speeches made to some purpose. The chief result of the expedition in Mr. Schoolcraft's view was the discovery of the source of the Mississippi in a lake to which he gave the name Itasca. A number of minor explorations were made by George Catlin and Featherstonehaugh in 1835 , by Jean Nicollet in 1836 , and by David $D$. Owen in 1847 . This last expedition was sent by the government to locate the boundary between Canada and Minnesota. An extensive literature was the outcome of the last expeditions. In 1872 the legislature of Minnesota authorized a geological and natural history survey of the State. The geological portion was finished in 1899; other branches are still in progress.

\section{Settlements}

The settlement of a new region is a long and hazardous undertaking. The explorer is soon fol-

Keating, Expedition to St. Peter's River, II. ch. v.

2 Journal of W. T. Boutwell, Minn. Hist. Soc. Pub., I. 153. 
lowed by the trader and the missionary, who in turn Traders. are followed by men seeking new homes. Thus settlements come to be made, and a permanent popuMissionar lation grows up. Nicolas Perrot established possibly the first trading post in the West at the mouth of the Black River. This was in 1685 . Then came Le Sueur, who in 1695 built a house on Isle Pelee not far above Lake Pepin. The hostility of the Indians prevented trading, and nothing was done by the French to establish trade relations until 1728 , when The Fren traders.

a fort was erected on Lake Pepin. The builder of it, Pièrre Paul, was forced to give up his post, and in 1752 another attempt was made at the same place with a similar result. Louis Denis, the Sieur La Ronde, in 1726 was given a concession for a trading post at Chagoumigan on Lake Superior. The French carried on considerable traffic with the Indians, but their trade was extremely hazardous. North of the French the English had scized the land about Hudson Bay on the strength of the discoveries of Henrick Hudson and the two French explorers, Radisson and Grosseillier. ${ }^{1}$ The Hudson Bay Company was formed under a charter from Charles II., and steadily resisted any attempt of the French to build posts or to trade in the Northwest so long as Canada remained under the control of the French. ${ }^{2}$ This hostility was transferred to the American companies established after 1783 , and as a result a long and bitter warfare was carried on between the Hudson Bay Company and the Northwestern Fur Company, and its successor the American Fur Company which

1 See page 5 .

2 See article on "Hudson Bay," Minn. Hist. Soc. Pub., I. 207. 
was organized in I808 under a charter from the New York legislature. $^{1}$ The War of 1812 retarded the business of the latter organization so that it did not really get into the field until after its close. By 1830 the company had erected posts at Madeline Island and La Pointe, Wisconsin, and Mendota in Minnesota.

Various settlements now made their appearance. The erection of Fort Snelling had been ordered by Congress as early as I 819 , but the fort was not built lements. until 1822. Ten years before this Lord Selkirk had established a colony on the Red River, where a grant of land had been given him by the Hudson Bay Company. The colony suffered so severely from locusts that a large number of its members left their new homes in 1827 , and came to Fort Snelling, which was then a flourishing post. In 1837 the Indians ceded all of their land east of the Mississippi to the United States. This was a memorable year for Minnesota, for it opened up some of the great resources of the State to the exploitation of actual settlers. ${ }^{2}$ Lumber companies were organized; towns appeared at St. Croix Falls and Marine Mills in the following year. The first house upon the present site of St. Paul was also built in this year, 1838. Stillwater was founded in 1843 , and St. Anthony in 1847. In 1849 Minnesota was organized as a territory and had a population of $4940 .^{3}$

From the time when the white men first came into sionaries. Minnesota efforts were made to establish missions.

\section{The two companies were united in 1822 .}

2 Williams, History of St. Paul, 57. The payment was $\$ 300,000$ invested in five per cent stocks, $\$ 1$ ro,000 for mixed bloods, and $\$ 90,000$ to pay the debts of the tribe.

${ }^{8}$ See Appendix C. 
Some of the early explorers like Menard, Allouez, and Father Hennepin were missionaries, but they were not successful in establishing permanent missions. The first successful efforts to establish Christianity in Minnesota were made by the Roman Catholic Church, but representatives of other denominations appeared in the field early in the present century. The work of the trader and pioneer was softened and directed toward better things by these earnest men, among whom will always be remembered Boutelle, Stearns, and the Pond Brothers. The first Indian mission in the territory was at Sandy Lake in 1832. Other missions were established at Leech Lake in 1834 , Lakes Harriet and Calhoun in 1837, and later at Fond du Lac, Pokegoma, La Pointe, Yellow Lake, Lac qui Parle, Mendota, and St. Paul. ${ }^{1}$

\section{The Organization of Minnesota Territory}

Minnesota is of dual origin. Part of the territory of which the present State is formed was a portion of Origin of the Northwest Territory, the remainder was the northeastern portion of the Louisiana purchase. The Mississippi divides the two great regions. There was a marked difference in the heritage of the two parts. The Northwest Territory was presented with a territorial government, religious liberty, personal rights, and educational endowments. The other region retained some of its Spanish and French laws, but the merging of the two sections largely obliterated them, and substituted therefor those of the Northwest Territory. It is interesting to note that Minnesota east 
Various jurisdictions.

The

Territory of Wisconsin.

of the Mississippi passed under seven jurisdictions, viz., the Northwest Territory 1787, Indiana I800, Michigan I 805 , Illinois I 809 , Michigan a second time in 1819 , Wisconsin 1836 , and Minnesota 1848 . The part west of the Mississippi also had a varied experience. The province of Louisiana came into the possession of the United States in I803. Out of this Louisiana Territory was formed in 1805 , Missouri in 1812 , Michigan in 1818 , Wisconsin in 1836 , and Iowa in 1838. Each included Minnesota, and finally, in I 848 , the territory by the present name was organized.

Wisconsin was admitted into the Union on the 29th day of May, I848; but the new State did not include that part of the territory of Wisconsin which lay west of the St. Croix River, and Congress made no provision for the government of this area. Accordingly, in the following August, a public meeting was held at Stillwater to consider whether the laws of the old territory of Wisconsin were still in force in this region. A letter from John Catlin, former secretary of the Territory of Wisconsin, was read, in which he endeavored to show that those parts of the Territory which had not been included in the State still constituted the Territory of Wisconsin. Hence he said that it was only necessary for the people to elect a delegate to Congress, and that he, as acting governor of the Territory, would issue a proclamation for an election to fill the vacancy if the people would act under it. Minnesota was in a peculiar position. The portion west of the Mississippi had been left without government by the admission of Iowa in 1846 , and now the admission of Wisconsin into the Union left a still wider territory without government. 
The former secretary of Wisconsin, Mr. Catlin, moved his residence from Madison to Stillwater, and as acting governor of the surviving Wisconsin Territory issued a proclamation, October 9, ordering a special election to fill the vacancy in the office of delegate. The election was held on October $30 ;^{1}$ Election of delegate. the Hon. H. H. Sibley, being chosen delegate, proceeded at once to Washington. $\mathrm{He}$ was permitted by courtesy to occupy a seat on the floor of the House of Representatives, but progress in the organization of a new territorial government was exceedingly slow. A bill for this purpose was prepared by Senator Douglas with the advice of Mr. Sibley. ${ }^{2}$ Efforts were made to bring Minnesota into the great slave controversy, and many amendments were added to the bill to delay its passage, but it was finally passed because the Senate refused to recede from its position. ${ }^{3}$ The Territory was thus created March 3, 1849, with the Missouri River as the western boundary.

The territorial act provided for the appointment of the usual executive officers, consisting of governor Provisions of and secretary. The judicial officers were a chief government. justice, two associates, a district attorney, and a mar- officers. shal. All of these officers were appointed by President Taylor. The first appointment by the President was that of Hon. Edward C. McGaughey of Indiana as governor, which the Senate refused to confirm. ${ }^{4}$ Pennington of New Jersey was asked to accept the position, but he declined; a third selection was made,

1 See account of organization in Minn. Hist. Soc. Pub., I. 53-68.

2 Congressional Globe, 30th Congress, $2 \mathrm{~d}$ session, I, $58 \mathrm{r}$.

8 West, Life and Times of Sibley, ch. iv.

4 Neill, History of Minnesola, ch. xxii. 
Duties of executive officers.

and, happily for the State, Alexander Ramsey consented to serve.

The duties incumbent upon the governor were those usually devolving upon such an officer. $\mathrm{He}$ was commander-in-chief of the militia, he had power to grant pardons, to enforce the laws, and to appoint officers with the consent of the Council. In addition to these duties he was to act as Indian agent of the Federal Government. The term of office was four years. The secretary of the Territory was appointed for a similar term of office. His duties were largely those of a recording officer. In case of a vacancy in the office of governor the secretary was authorized to act until the appointment of another governor by the President of the United States. The legislature consisted of an assembly of eighteen members and a council of nine members, elected by the people. The time of service for the first was one year, for the second two years. ${ }^{1}$

Judiciary.

A regular system of courts was soon established. The territory was divided into three judicial districts, which made it possible to hold district courts, for the supreme court judges also acted as district judges. Justices of the peace were appointed, so the Territory had a complete court system.

Other provisions.

Liberal provisions were made in the organic act for the erection of public buildings and the establishment of an educational system. Every sixteenth and thirtieth section in each township in the territory was granted for the partial maintenance of public schools. ${ }^{2}$

1 See Appendix G.

${ }^{2}$ N.B. The instructor should here refer to the Territorial Act contained in Appendix G. Students should become thoroughly acquainted with its provisions. 


\section{The Organization of Minnesota Territory 15}

To the inhabitants of the Territory were extended all the rights, privileges, and immunities which they possessed as inhabitants of the Territory of Wisconsin, and some further privileges which were specified in the act organizing the Territory. It was under this provisional government that Minnesota prepared for statehood. 


\section{CHAPTER II}

\section{MINNESOTA AS A STATE}

\section{REFERENCES}

West, Life and Times of H. H. Sibley, St. Paul, 1889; Minnesota Historical Society Publications, VIII ; Legislative Manual, I897 and 1899; Minnesota Convention Debates, 2 vols.; early volumes of The Pioneer Press; Congressional Globe, 34th and 35th Congresses; Heard, History of the Sioux Rebellion, New York, 1863; Bryant, Indian Massacres in Minnesota, St. Paul, 1872; Minnesota in the Civil and Indian Wars, St. Paul, 1890 (prepared by Board of Commissioners appointed by the legislature, Act of April 16, 1889); Farrar, Five Years in Minnesota, London, 1880; McClurg, Minnesota as it is in 1870, St. Paul, 1870; Carleton, The Seat of Empire, Boston, 1870; bound volume of pamphlets under the title of Five Million Dollar Loan, in the Minnesota Historical Society library; article on "Minnesota," in the Encyclopadia Britannica.

\section{The Enabling Act}

Minnesota applied for statehood when the slavery strife was at its height. From the time of the adoption of the Federal Constitution up to 1850 thirty States had been admitted to the Union. Half of

The history of the time. these were slave, half free States. The North, growing more rapidly from 1850 than the South, threatened the balance thus far maintained; California was admitted in 1850 as a free State, and the equilibrium was destroyed. The Kansas-Nebraska strife had begun when Minnesota knocked for admission to the 
Federal Union ${ }^{1}$ her admission was looked upon with disfavor by a large number of Southern representatives and senators in Congress, for it would add to the already increasing ascendency of the North.

A bill was introduced into the House on December 24, 1856, by Henry M. Rice, the territorial delegate, authorizing the people of the Territory of Minnesota The bill and its provisions. to frame a constitution and State government. This bill was at once referred to the Committee on Territories. On the last day of January, 1857, Hon. Galusha A. Grow, the chairman of the committec, reported a substitute for the original bill which contained three additional provisions: first, a few changes in the western boundary; second, concurrent jurisdiction of rivers forming a common boundary; and third, free navigation of such rivers by citizens of the United States. In other respects the two bills were identical. Delegates, to be chosen by the people, were to meet at the territorial capital on the second Monday of July. These delegates were to determine by vote whether a State government should be formed, and if so to draft a constitution. It was also provided that the constitution should include the following provisions : every sixteenth and thirty-sixth section in each township was to be reserved as a nucleus for a public school fund; the proceeds of the sale of seventy-two sections were to be reserved as an endowment for a State university; and the salt springs and six sections of contiguous land for each spring were to remain in the control of the State, while five per cent of the sales from public lands within the

1 For the Kansas-Nebraska controversy see Wilson, Division and Reunion, 1829-1889, ch. vii. 
Passage of the bill.

State were to be expended for public improvements. ${ }^{1}$ With these provisions the bill went to the House.

In the passage of the bill through the House there was some opposition from Southern representatives, although a number of the Northern members of the House voted against the bill. On February 2, 1857, the bill reached the Senate, and was again referred to the Committee on Territories. The bill was reported back February 18 by the chairman, Stephen A. Douglas, without amendment. Three days later the bill came up for consideration. ${ }^{2}$ An amendment was immediately offered, providing that only citizens of the United States should vote for delegates to the constitutional convention. The discussion continued until nearly the end of the session. ${ }^{3}$ The amendment was finally carried by a vote of 27 to 24 , and the bill, then put on its final passage, was passed by a vote of 47 to I. But upon the announcement of the result John P. Hale, of New Hampshire, gave notice that he would move to reconsider the vote. On February 24 he did so, and the following day the Senate rejected the amendment, and passed the bill as it came from the House. ${ }^{4}$

\section{The Constitutional Convention}

The people of Minnesota began the making of a constitution by electing delegates on the first Monday in June, 1857. A great deal of uncertainty prevailed

1 See Appendix H for Enabling Act.

2 Congressional Globe, 34th Congress, 3 d session, Appendix, 402.

8 For opposition speeches, see article by Professor F. F. Moran, Minn. Hist. Soc. Pub., VII.

4 Congressional Globe, 34th Congress, 3d session, 849-865, 872-877. 
in the Territory as to the boundaries of the counties and districts, so that there was some doubt as to who were legally elected delegates. This uncertainty was The dispute over meeting of the convention. heightened, as the time of the convention drew near, by charges of the two parties against each other. ${ }^{1}$ Rumors were current that underhanded work was going on; everything was ripe for serious disagreement. The Enabling Act named the day of the convention, but said nothing in relation to the hour of meeting. The Republicans feared that the Democrats might anticipate them, and effect an organization of the convention before they could get together. In order to prevent this possibility they assembled in the chamber of the House of Representatives at midnight preceding the day designated in the bill. At noon on the second Monday of July, the Democrats marched to the capital, but found the Republicans in possession. The secretary of the Territory, Charles L. Chase, proceeded to call the convention to order for the Democrats. Simultaneously Mr. J. W. North did the same for the Republicans; the Democrats moved to adjourn, and did so, leaving the Republicans in the hall. On the next day the Democrats organized in the council chamber. Each body claimed to be the constitutional convention, and proceeded to frame a constitution. ${ }^{2}$

The Democrats on August 8 offered conciliation, but in their peace offering stated that the legal character of their convention was not to be called into question. For The the ten days the Republicans made no reply, but at the Constitution.

${ }^{1}$ See files of The Pioneer Press for 1857 in the Minnesota Historical Society's Library, St. Paul.

${ }^{2}$ Minnesota Constitutional Debales, first papers of I. and II. 
end of that time appointed a conference committee to meet a committee of the Democrats. After considerable discussion an agreement was reached, and the two divisions of the convention accepted the same constitution on August 29. On the thirteenth day of October, I 857 , the people adopted the constitution by the vote of 30,055 yeas to 57 I nays.

President Buchanan notified Congress, January I I, I858, that he had received a certified copy of the constitution from the governor of Minnesota Territory, Samuel Medary. Upon receipt of the same the Senate referred the matter to the Committee

Admission to on Territories, and a bill for the admission of the the Union. State to the Union was reported by that committee on January 28 . A very serious opposition to the admission of Minnesota was at once manifested; it was alleged by the Southern leaders that the census had not been taken as provided in the Enabling Act, and that it was not possible to know whether the Territory was entitled to statehood. The bill for admission was finally passed by the Senate, April 7, 1858. In the House the opposition was much the same. The personnel of the body had changed since the passage of the Enabling Act, but the debate on representation still remained the prominent part of the opposition. The bill was passed May II, I858, by a vote of 157 to 38. Although the opposition was prolonged, there was no good reason for not admitting Minnesota to the Union.

\section{Organization of the Government}

At the same election at which the people of Minnesota adopted the constitution by such a large 
majority, State officers and three congressional representatives were chosen. In the following December, at the meeting of the legislature, two senators were elected, Henry M. Rice and James Shields. The senators and representatives proceeded to Washington early in the year and applied for admission. In the Senate the credentials of the senators were presented May 12, but unexpected opposition was developed on the ground that States alone could elect senators, and as the credentials of the Minnesota representatives were signed by the governor of the Territory they were not entitled to seats in the Senate. Two days later, however, both senators were admitted.

Similar opposition appeared in the House. It, however, was stronger, the contention being that a Territory could not elect representatives to Congress. $^{1}$ The matter was referred to the Committee on Elections, and in a few days majority and minority reports were presented. A long discussion followed, but the House finally adopted the majority report, and Messrs. Cavanaugh and Phelps were sworn in May 22, $1858 .{ }^{2}$ Minnesota was now a member of the Union in full standing, represented in both houses of Congress.

1 Congressional Globe, 35th Congress, Ist session, 2275, 23 I0. See also Minn. Hist. Soc. Pub., VIII. part 2.

2 Minnesota was allowed two representatives instead of the three elected until the census should be completed. The apportionment was one representative to 93,420 persons. It was feared that the enumeration would not reach 280,260 . The three representatives cast lots to determine which two should have seats in the House. Mr. Becker was unsuccessful. 


\section{io. Minnesota in the Civil War}

But three years of statehood had passed when the Civil War began. The history of Minnesota during those years had been peaceful. Her people were busily engaged in taking up and improving farms, building towns, and in establishing industry. In 1860 the population of the State reached I72,123. Out of this number 24,020 enlisted in the various arms for service in the Federal forces. If this number were reduced to a three-year basis the proportion Troops from would still be large, 19,693. ${ }^{1}$ The patriotism of the Minnesota. State can still further be attested by the prompt answer to the call of the President on that fateful day of April, I86r. Governor Ramsey was in Washington at the time, and tendered personally a full regiment of one thousand men for the use of the government. These were the first troops accepted by the President. Regiment after regiment was organized under the various calls for troops, until eleven regiments of infantry, one regiment of heavy artillery, two companies of sharpshooters, four regiments of cavalry, and three batteries of light artillery went to the front from Minnesota. These troops took part in the battles of Bull Run, Fair Oaks, Harrison's Landing, Antietam, Fredericksburg, Chancellorsville, Gettysburg, Petersburg, Chickamauga, Mission Ridge, the Atlanta Campaign, Sherman's March to the Sea, and the movement against Vicksburg. ${ }^{2}$

1 World's Almanac, 1899, 95.

2 See Minnesota in the Civil and Indian Wars. 


\section{The Sioux Massacre}

While Minnesota was so nobly aiding the cause of the Union, the Sioux Indians, under the excitement bred by a bitter hostility to the whites, began the ravaging of towns and villages on the borders of the settlement. The government of the United States as early as 1815 had negotiated a treaty of friendship and amity with the Sioux. At another time, 1830, the treaty was confirmed, and an annuity of $\$ 3000$ with goods and presents was promised to them. Again in 1837 a further treaty was made by which the United States came into the control of a large tract of territory within the present State of Wisconsin. ${ }^{1}$ This treaty also provided for the payment of annuities. When the Territory of Minnesota was organized the population grew very rapidly, necessitating new treaties to preserve the friendly relations between Indian and white man. These treaties were arranged in 1851 and 1858 , and the United States came into the control of all the land in the State with the exception of two Indian reservations in the western and northwestern parts. In return for these large tracts of land the government agreed to pay the Indians through their chiefs large annuities for a period of fifty years from I855. Here is where the trouble arose.

The payment of the annuities was delayed by the failure of Congress to make the appropriations. The Indians became greatly dissatisfied. When, finally, an appropriation was passed, the traders and halfbreeds living on the reservations asked that payment 
Massacre at Spirit Lake, 1857.
Attempts to civilize the Sioux.

first be made to them of the debts contracted by the Indians. There seems to be no doubt that a very large part of the money intended for the Indians went into the hands of these men. Undoubtedly the Indians were robbed through the connivance of the agents of the Government. ${ }^{1}$ Just at this juncture an outlaw chief, Inkpaduta by name, had, with the aid of a band of Indians, massacred the settlers of Spirit Lake, a small hamlet in Iowa. ${ }^{2}$ The annuity payments which were being made by the government at the time were ordered stopped. As a condition of continued payment the delivery of Inkpaduta was required of the Sioux. The Indians immediately attempted to capture the outlaw and his band, but without success. Advised by the Indian agents that the Sioux should not be held responsible for the deeds of a few outlaws, the annuities were paid. No further attempts were made to punish the crime. The Indians regarded this as a sign of weakness, and, impressed by the panic created by a small band of warriors, they began to think that the whole Sioux nation might avenge their wrongs and gain possession of the lands formerly owned by them.

By the treaty of 1858 the government expected to break up the tribal and community system existing among the Sioux, with the hope of getting the Indians to engage in farming. Thus there came to be what Major Galbraith, the Sioux agent, called two distinct parties among these Indians, the "Scalp Locks and Blankets" and the "Cut Hair and

${ }^{1}$ See Judge Young's report, published in Bryant, Indian Massacres in Minnesota, 36.

2 Ibid., 39. 
Breeches." The farming Indians were in the minority, and needed the constant protection of the government. Their prosperity irritated and exasperated the others, and the natural spirit of hostility to the whites was fed by grievances, prejudice, and fear. These led to the organization of a plot and the massacre. Little Crow was the instigator, encourager, and director of the conspiracy.

In August, I 862, the entire effective force for the defence of the frontier from Pembina to the Iowa The attack and defence. line did not exceed two hundred men. ${ }^{1}$ The Civil War was known to the Indians, and the time was regarded as favorable for their attempt. The first blow fell on the little town of Acton. Barely twenty-four hours later the upper and lower Sioux agencies were attacked. Several white persons were killed, and the buildings of the agencies totally destroyed. The refugees from all parts of the country made their way as rapidly as possible to Fort Ridgely and the town of New Ulm. On the 19th of August the town was attacked, and again on the $25^{\text {th }}$; after the severest fighting and heavy loss the Indians were driven back, but the people evacuated the town. A city of two hundred houses was left a mass of charred timbers. Foiled in their attempt on New Ulm, the Indians turned to the siege of Fort Ridgely. There were in the fort about 150 soldiers, besides refugees. Two attacks were made, both unsuccessful, the inmates holding out until reënforcements arrived.

While these Indian depredations were going on, volunteers were raised in Glencoe, Hastings, St. Peter, Minneapolis, St. Paul, and the older parts of

1 Judge Young's report, in Bryant, Indian Massacres in Minnesota, 54 . 
Checking the the State. An army of nearly I500 men was gathInsurrection.

ered under the leadership of General Sibley. The government of the United States did all in its power to aid the citizens in putting down the insurrection. Such concerted action checked the Indians, and after a number of engagements 2000 were captured. Of this number 303 were condemned to death by a court-martial. President Lincoln reprieved 265 of the number, so that only 38 were executed at Mankato, December 26, I862. Two other expeditions, under the command of Generals Sibley and Sully, were sent out by the Federal Government in 1863 and 1864 . These resulted in the complete subjugation of the Indians after the fights at Big Mound, Dead Buffalo Lake, Stony Lake, and the

Results of the Massacre. battle near the Missouri. The results of the Indian massacres are difficult to ascertain. In less than a week, it is estimated by some writers, 2000 persons were killed, and it is said that the population of eighteen counties, numbering about 30,000, fled from their homes. ${ }^{1}$ Major Galbraith, in speaking of the property destroyed or abandoned, says, "I believe I very nearly approximate the truth when I set it down at two millions of dollars." 2 The number of claims filed for examination before the Sioux Commission was 2940 , amounting to $\$ 2,500,000$. Contributions came in from all parts of the West for the support of the refugees. Despite the efforts of the State and National governments, many years were required to allay the distrust of the people after this, the greatest of Indian massacres.

${ }^{1}$ Bryant, Indian Massacres in Minnesota, 415, 416.

2 Ibid., 42 I. 


\section{The Building of Railroads}

Minnesota was just on the threshold of statehood when the agitation for railway construction began. Need of The highway from the central west to the Pacific passed through Minnesota, and if immigration and the wealth of the Northwest were not to be diverted to the north or the south of the Territory, something must be done to encourage the building of railways. It was pointed out by many writers and speakers at the time that Canada, by judicious aid to private companies, had increased her population sixty to seventy per cent. ${ }^{1}$ The experiences of Massachusetts, New York, Maryland, Virginia, South Carolina, and other States were referred to as examples for a similar policy in Minnesota.

Congress and the territorial legislature had already made large grants to railway companies, and as a Land grants and loans to result a marked extension of railroad construction was expected in the spring of 1858 . But the panic of 1857 was too much for these enterprises, and their promoters came before the legislature, asking the aid of the State. Several bills were presented in the legislature, but finally the two houses. agreed to submit the matter of railroad grants to the people, which was done on April 15, 1858. A favorable vote was cast for the proposition, and the grant to the railways was made a part of the constitution and could not be tampered with by future legislatures. By this amendment the State agreed to issue $\$ 100,000$

1 There is in the library of the Minnesota Historical Library at St. Paul a bound volume of pamphlets on the railroad experiences of Minnesota. An examination of it will be richly rewarded. 
in bonds when ten miles of road were ready for the rails, and \$100,000 more when fully equipped and running. Furthermore, the sum of $\$ 1,250,000$ was voted to each of four roads, which, however, were not to receive it until sixty-two miles of road were fully equipped and in operation. The State was secured in these loans by holding a first mortgage on the roads, lands, and franchises of the respective companies ; an additional security, consisting of 240 sections of land for each road, regarded as worth $\$ 6,224,000,{ }^{1}$ was provided for the redemption of the principal. Still further, in the case of non-payment of interest the roads were to pass into the hands of the State.

Bonds to the amount of $\$ 2,275$,000 were issued to the companies, which also had secured possession of the land, amounting to the vast acreage of $5,000,000$. Repudiation The State did not profit by these transactions and of the bonds. was no better off than before. There was not a mile of road in operation, and only 250 miles of graded roadbed. The State, under the pressure of public opinion, began foreclosure proceedings. The first batch of bonds, during this time, became due, and the State took possession of the properties of the roads, but, although the State held the lands, franchises, and roadbeds of the companies, still the people demanded that the question of the payment of the bonds by the State be submitted to a popular vote. The amendment adopted in 1858 was, in 1869 , expunged from the constitution and another substituted, forbidding the loaning of the credit of the State for internal improvements. ${ }^{2}$

1 See articles in The Pioneer and Democrat, March, 1858.

${ }^{2}$ Constitution of Minnesota, Art. IX., Sec. 10. 
In 1877 it was proposed to set aside the proceeds of 500,000 acres of land for the payment of the Attempts at payment. bonds. The people refused to do this. During these years public opinion had gradually shifted from repudiation to redemption. Another attempt was made, in I88I, to pay the obligations. An extra session of the legislature was called by Governor Pillsbury. The legislature finally authorized the payment of the outstanding bonds at fifty cents on the dollar. The pcople ratified the proposition of four years before, to set aside the proceeds from the sale of 500,000 acres to provide for redemption of the bonds issued to pay the debt. The long-standing obligation was thus wiped out.

The old companies having defaulted, the legislature in I 862 transferred the franchise to new companies. These began energetically to construct roads. The war retarded their progress, but with the close of hostilities labor was easier to obtain. By I870 a thousand miles of track were equipped and operated Growth of railroads. in the State. There are now fourteen railway companies in Minnesota, operating 6I98 miles of road and owning property valued at $\$ 1,093,879,267 . .^{1}$ Toward the building of these roads the Federal Government made the enormous grant of $17,621,952$ acres of land, and in addition to this the State has given to the companies 3,062, I4I acres, making a grand total of 20,689,093 acres.

Without railroads Minnesota could only have been a State of sparse population and small producing power. Railroads made it possible for her lumber, minerals, and agricultural products to reach all parts

1 See ch. viii. 139, on the taxation of railways. 
of the world. Although the cost of construction was heavy, nevertheless the attempts on the part of the people to encourage the building of roads were possibly justifiable. The State thereby early secured communication with other parts of the country.

\section{The Growth of the State}

The opening of the new century will see Minnesota with about one million eight hundred thousand people. By the federal census of 1900 the population was reported as $1,75 \mathrm{I}, 395$. The increase from I 890 to 1900 was 34.5 per cent. Divided with respect to nativity, Population. the population is one-third foreign and two-thirds native. ${ }^{1}$ Germany, Sweden, and Norway have contributed most largely to the foreign-born population of the State. The occupation of 39 per cent of the legal voters is farming, which shows the supremacy of agriculture in Minnesota. The principal cities and their populations as given by the State census of 1900 are: Minneapolis, 202,718; St. Paul, 163,632; Duluth, 52,969; Winona, 19,7 I4; Stillwater, I2,318; Mankato, 10,599; and St. Cloud, 8663. Besides these are twenty-five other towns varying in population from 2000 to 8000 .

The wealth of the State has steadily grown in the last twenty years. By the census of $\mathrm{I} 880$ the per capita wealth in the State was \$IOI4. This had risen to $\$ 1300$ in I890. The same census gives Wealth. $\$ I, 69 I, 85 I, 927$ as the total wealth of the State. A large part of Minnesota's wealth comes from agriculture. The estimated value of farm products in

1 See Appendix E for an analysis of population. 
the State in 1890 was $\$ 71,238,230$. The number of farms at the time was 116,861 , embracing $18,663,645$ acres. The value of these farms was reported at $\$ 340,059,470$, of which farms valued at \$1 $19,290,539$ are mortgaged for $\$ 37,709,574$. Homes to the value of $\$ 81,556,693$ are encumbered to the amount of $\$ 27,953,413$. $^{1}$

Manufacturing and mining are extensively carried on in the State. Lumber, sash, doors, shingles, flour, furniture, iron, and steel are the chief products in manufactured articles. The value of these reached in $1890 \$ 192,033,478$. The mining industry has developed to wonderful proportions. In I 899 some $7,000,000$ tons of iron ore were taken out. Stone of good quality of many varieties is found in different parts of the State.

\section{CHRONOLOGICAL ARRANGEMENT OF THE HISTORY OF MINNESOTA}

(Adapted from a similar table in The Legislative Manual, 1899.)

1634. Jean Nicollet, an explorer from France, who had wintered in the neighborhood of Green Bay, brought to Montreal the first mention of the aborigines of Minnesota.

1658-59. Groseilliers and Radisson wintered among the Sioux of Mille Lacs region, Minnesota.

1661. Father René Menard left Keweenaw, on Lake Superior, to visit the Hurons, then in northern Wisconsin, and was lost near the sources of the Black and Chippewa rivers.

1 Census of 1890 , mortgage statistics. 
1679. Daniel Greysolon Du Lhut (Duluth) ascended St. Louis River to Fond du Lac, and held a council with the Sioux. Du Lhut, in June, 1680, by way of the St. Croix river, reached the Mississippi, and met Hennepin.

1680. Louis Hennepin, after captivity in the village of the Mille Lacs Sioux, first saw the Falls of St. Anthony.

1685. Nicholas Perrot first planted the cross and arms of France on the soil of Minnesota, and first laid formal claim to the country for France. He built a fort on Lake Pepin, near Lake City.

1695. Le Sueur built a fort on Isle Pelee, in the Mississippi, below Prescott.

I697. Treaty of Ryswick. France acknowledges England's claim to Hudson Bay.

1700. Le Sueur established Fort L. Huillier, on the Blue Earth River (near the mouth of the Le Sueur), and first supplied the Sioux with firearms.

1726. Sieur La Ronde was given concession at Chogoumagin.

1728. The French established a third fort on Lake Pepin, with Sieur de Lapperriere as commander.

1763. By the Treaty of Versailles, France ceded Minnesota, east of the Mississippi, to England, and west of it to Spain. 1766. Captain Jonathan Carver visited St. Anthony Falls and Minnesota River.

1783. The Treaty of Paris and the cession of all lands claimed by England east of the Mississippi to the United States. Northwestern Fur Company organized.

1796. Provisions of the Ordinance of 1787 extended over the Northwest Territory, including the northeastern third of Minnesota, east of the Mississippi River.

1798-99. The Northwestern Fur Company established itself in Minnesota.

1800. May 7, that part of Minnesota east of the Mississippi became a part of Indiana by the division of the Northwest Territory.

1803. December 20, that part of Minnesota west of the Mississippi, for forty years in the possession of Spain as a part of Louisiana, was ceded to the United States by 
Napoleon Bonaparte, Emperor of the French, who had just obtained it from Spain.

1803-04. William Morrison, the first known white man to discover the source of the Mississippi River, visits Elk Lake and explores the streams entering into the lake forming the head of the river.

1805. Upper Louisiana was organized as Missouri Territory. Captain Z. M. Pike visited Minnesota as the agent of the government for the purpose of establishing relations with the Indians, and to obtain the Fort Snelling reservation from the Dakotas.

1812. The Dakotas, Ojibways, and Winnebagoes, under the lead of hostile traders, joined the British during the war. Red River colony established by Lord Selkirk.

1815. First treaty with the Sioux Indians.

1819. Minnesota, east of the Mississippi River, became a part of Crawford County, Michigan. Fort Snelling established and a post at Mendota occupied by troops, under command of Colonel Leavenworth.

1820. Corner-stone of Fort Snelling laid September 10. Governor Cass visits Minnesota and makes a treaty of peace between the Sioux and the Ojibways, at Fort Snelling. Colonel Josiah Snelling appointed to the command of the latter post.

1823. First steamboat arrived at Mendota, June. Major Stephen H. Long explores Minnesota River and the northern frontier. Beltrami explores sources of the Mississippi. 1825. Great flood on the Red River; a part of the colony driven to Minnesota and settle near Fort Snelling.

1832. Schoolcraft explored the sources of Mississippi River; first mission established at Leech Lake, by Rev. W. T. Boutwell, late of Stillwater.

1834. The portion of Minnesota west of the Mississippi attached to

Michigan. General H. H. Sibley settles at Mendota.

1835. Catlin and Featherstonehaugh visit Minnesota.

1836. The Territory of Wisconsin organized, embracing all of Minnesota east of the Mississippi, the rest being attached to Iowa. Nicollet visits Minnesota. David D. Owen visits Minnesota. 
1837. Governor Dodge of Wisconsin made a treaty, at Fort Snelling, with the Ojibways, by which the latter ceded all their pine lands on the St. Croix and its tributaries; a treaty was also effected at Washington with a deputation of Dakotas for their lands east of the Mississippi. These treaties led the way to the first actual settlements in the State.

1838. The Dodge treaty ratified by Congress. Franklin Steele makes a claim at St. Anthony Falls. Pierre Parrant makes a claim and builds a shanty on the present site of St. Paul.

1839. St. Croix County established.

1840. The chapel of "St. Paul" built and consecrated, giving the name to the capital of the State.

1843. Stillwater settled.

1846. August 6, the Wisconsin Enabling Act passed.

I847. The Wisconsin constitutional convention meets.

1848. May 29, Wisconsin admitted, leaving Minnesota (with its present boundaries) without a government. August 26 , the "Stillwater convention" held, to take measures for a separate territorial organization, and asking that the new territory be named Minnesota. October 30, H. H. Sibley elected delegate to Congress.

1849. January I 5, H. H. Sibley admitted to a seat in Congress. March 3, the bill organizing the Territory of Minnesota passed. March 19, its territorial officers appointed. June I, Governor Ramsey declared, by proclamation, the Territory organized. September 3, the first territorial legislature assembled.

1850. Great flood; highest water ever known. Minnesota River first navigated by steamboats. Census shows 6,077 inhabitants.

1851. Permanent location of capital, university, and penitentiary; another flood. July 23, treaty of Traverse des Sioux completed.

1852. July 26, the treaty ratified by the United States Senate.

1853. W. A. Gorman appointed governor. The capitol building completed. 
1854. Celebration of the opening of the Rock Island Railroad the first road to the Mississippi River. Large immigration begins.

1857. Enabling Act passes Congress, February 26. Governor Sam Medary (appointed by Buchanan) arrives on April 22. Legislature passes a bill to remove the capital to St. Peter, but it fails to accomplish the object. Inkpaduta massacre, April. Land Grant Act passes Congress. April 27, extra session of the legislature to apportion land grant. June I, constitutional convention assembles. Real estate speculation reaches its height, and is checked by the financial panic, August 27. Great reverses and hard times. Census shows 150,037 population. October 13 , Constitution adopted and State officers elected.

1858. State loan of $\$ 250,000$ negotiated. Five million loan bill passed; is voted on April 15 , and passes. Great stringency in money market. State admitted May II. State officers sworn in May 24.

1859. Hard times continue to intensify. "Wright County War." "Glencoe" and "Owatonna" money issued. Work on the land grant roads ceases. Collapse of the five million scheme. First export of grain this fall. Hard political struggle; the Republicans triumph.

1860. Federal census, 172,123.

1861. April 13. President's proclamation for troops received; the first regiment recruits at once; June 22, it embarks at Fort Snelling for the seat of war.

1862. Call for 600,000 men. August 17 , massacre at Acton; August 18, outbreak at lower Sioux agency; 19th, New Ulm attacked; 2oth, Fort Ridgely attacked;

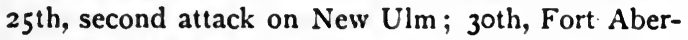
crombie besieged; September I, the bloody affair at Birch Coolie. September 19, first railroad in Minnesota in operation, between St. Paul and Minneapolis. September 22, battle of Wood Lake; 26th, captives surrendered at Camp Release; military commission tries 321 Indians for murder, rape, etc.; 303 condemned to die; December 26, 38 hung at Mankato. 
1863. General Sibley's expedition to the Missouri River; July 3, Little Crow killed; July 24, battle of Big Mound; July 26, battle of Dead Buffalo Lake; July 28, battle of Stony Lake.

1864. Large levies for troops. Expedition to Missouri River under Sully. Inflation of money market. Occasional Indian raids.

1865. Minnesota regiments return from the Civil War and are disbanded. In all 25,052 men were furnished by the State. Census shows 250,000 inhabitants.

1866-72. Rapid railroad building every where; immigration heavy; "good times" prevail, and real estate inflated.

1869. College work begins in the State University.

1873. January 7, 8, and 9, polar wave sweeps over the State; seventy persons perish. Grasshopper raids begin and continue five seasons.

1877. Biennial session amendment adopted. Proposal to pay railroad bonds.

1878. May 2, three flouring mills at Minneapolis explode; eighteen lives lost.

1880. November 15, portion of the hospital for the insane at St. Peter destroyed by fire.

1881. March I, the State capitol destroyed by fire. Railroad bonds redeemed.

1884. January 25 , State prison partially burned.

1886. April 14, a cyclone strikes the cities of St. Cloud and Sauk Rapids, demolishing scores of buildings and killing about seventy people.

1887. Important legislation regarding the liquor traffic, common carriers, and elections.

1889. The legislature enacts the Australian system of voting in cities of 10,000 and over. The first electric street railway started in the State, at Stillwater.

1890. United States census shows a population of 1,301,826. July, accident at Lake Pepin, one hundred people drowned; cyclone at Lake Gervais.

1891. June 15 , a destructive cyclone started in Jackson County, near the town of Jackson, traversing Martin, Faribault, Freeborn, Mower, and Fillmore counties. 
1892. June 7, Republican national convention held at Minneapolis. The Australian system of voting used at the November general election.

1893. The legislature authorizes the appointment of a capitol commission to select a site for a new capitol, and provides a tax of two-tenths of a mill for ten years to pay for the site and the erection of a building. A great financial crisis causes the failure of several banks and many mercantile and manufacturing establishments in the larger cities of the State.

1894. September I, destructive forest fires start in the neighborhood of Hinckley, in Pine County.

1895. Population by State census I, 574,619.

1896. The Red Lake Indian reservation partly opened to settlement.

1897. July 2, the monument at Gettysburg to the First Minnesota Regiment was dedicated.

1898. July 27 , the corner-stone of the new capitol was laid. Minnesota supplied four regiments for service in the Spanish war, being the first State, May 7, to respond to the President's call. October 5, the Pillager Indians attacked United States troops near Sugar Point, Leech Lake.

1900. United States census shows a population of 1,751,394. 


\section{CHAPTER III \\ ORGANIZATION OF THE STATE}

\section{5. REFERENCES}

Bryce, The American Commonwealth, chs. xxxvi., xxxvii., xxxix.; Wilson, The State, secs. 1088-1105 (revised edition); Fiske, Civil Government in the United States, chs. vi., vii.; Hitchcock, American State Constitutions (a good book to show the nature of commonwealth constitutions, and the necessity of amendment). The constitution of Minnesota may be found in the Legislative Manual, published every two years by the Secretary of State, and in Poore, Charters and Constitutions. The chief parts are printed in Appendix J.

\section{I6. Restricted Powers of the State}

In the preceding chapters we were told how the people of Minnesota framed a written constitution under the limitations of the Constitution of the United States. Thus restricted, they were not able to do all the things that belong to a sovereign people, but in the conduct of their immediate affairs and matters pertaining to local government they were supreme. The coining of money, keeping an army or navy, declarPowers of a ing war, or making treaties was forbidden to them ;
State. nor could they abridge the rights of citizens of other States, or pay the debts that might be incurred in the aid of any rebellion; but the Federal power granted them the right of representation in Congress, of taking part in the election of President and Vice-President, and self-protection from invasion. ${ }^{1}$ With this

1 Constitution of the United States, Art. I., Secs. 8, 9. 
agreement the State constitution was framed, ratified by the people as the instrument under which they were to be governed, and accepted by Congress as in accord with the Constitution of the United States.

When we speak of the word constitution we mean a written instrument which sets forth the method of government, the division of powers, and the rights and privileges of the people. Such an instrument contains a preamble, a bill of rights, the provisions for a government, and various restrictions on the power of government, and provisions treating of finance, amendment, and franchise. The object of a written constitution is to give definite form and authority to government, to protect individuals against that government, and to establish justice.

\section{The Constitution, Preamble, and Bill of Rights}

The constitution of Minnesota became the organic law on May II, I858. When ratified by the people it contained, in addition to the preamble, fifteen articles. The first of these is the Bill of Rights; then follow in succession the articles on Boundaries; DisContents of the tribution of the Powers of Government into the Legislative, Executive, and Judiciary departments; the Elective Franchise; School Funds, Education, and Science ; Finance and Banking; Corporations ; Counties and Townships; Militia; Impeachment ; Amendments; and the Schedule. ${ }^{1}$

The preamble is the enacting clause of the constitution, and sets forth the motive and design of the

Constitution defined.

Constitution.

Preamble.

1 See Appendix J, containing parts of the constitution. 
instrument, and who are the enactors. ${ }^{1}$ In order that there may be no dispute in regard to the rights the people possess and the powers with which the government has been endowed, a bill of rights, enumerating the privileges of the people, is inserted in the constitution. The bill of rights is in one sense the epitome of the precious privileges won by the Anglo-Saxon race. In it are to be found assertions of the right to reform or modify the government, of freedom of speech, of the press, and of religious liberty. A number of legal rights are contained therein, such as trial by jury, freedom from excessive bail, from unreasonable search, from imprison-

Bill of Rights.

Legal Rights. ment for debt, and the prohibition of ex post facto laws and bills of attainder. The basis of criminal procedure is also provided for, in that every person charged with committing a crime must be indicted by the grand jury before he is put upon trial. ${ }^{2}$

"Every person is entitled to a certain remedy in the law for all injuries to his person, property, or character; he ought to obtain justice freely and without purchase; completely and without denial; promptly and without delay, conformable to the laws." 3 In order to secure such an end the rights spoken of above and along with them the privilege of the writ of habeas corpus can be denied to none. ${ }^{4}$

The other articles of the constitution are construc-

1 The instructor should make clear the reason for the preamble and the bill of rights.

${ }^{2}$ See ch. vii. on Administration of Justice.

${ }^{3}$ Constitution of Minnesota, Art. I., Sec. 8.

4 The instructor will find it profitable to have the students make a comparison of the bill of rights in the State constitution with that of the United States. 
tive in that the frame of the government is outlined in them. With these we shall have more to do in other parts of the book, and therefore postpone for the time their discussion.

\section{Amendment and Revision of the Constitu- TION}

The people retain the important power to amend and revise their constitution from time to time. All amendments and revisions must be finally submitted to them or to their representatives. Amendments are made through the legislature, revisions by a convention called by the legislature. ${ }^{1}$

Any member of the legislature may offer an amendment to the constitution, which, if it receives a majority vote of both houses, is published with the laws passed at the same session, and then submitted to the people (at the next election) for acceptance or rejection. If a majority of all the electors, voting at the election, favor the amendment, it becomes a part of the constitution. In case two or more amendments are submitted at the same time, the law provides that each shall be voted upon separately. In this manner of amendment there is a danger. The legislature may submit matters that are not in any sense constitutional. Thus questions which the legislature wishes to avoid may be put in the form of an amendment to the constitution, and the responsibility of further action evaded. Amendments becoming part of the constitution in this manner may make that

Power to revise. 
instrument a body of laws instead of a set of principles.

The legislature does not possess the power of revising the constitution, but it may take the first steps toward that end. Whenever two-thirds of the members of each house deem it necessary to revise the constitution a convention may be called, but not

Convention. until the question, "Shall a convention be called?" is submitted to the people at the general election of members to the legislature. If a majority of the electors declare for a convention, the legislature at its next session must provide for one. The constitution is explicit about the time and membership of the convention. The meeting of delegates must take place within three months after the election, and the delegates are chosen in the same manner and the same number as the members of the House of Representatives. The method of amendment and revision are shown in detail in the order of procedure given below. ${ }^{1}$

\section{I. AMENDMENT}

(a) Proposal by members of the legislature.

(b) Acceptance by a majority vote of the legislature.

(c) Submission to electors.

(d) Ratified or rejected by electors.

II. REvision

(a) Proposed by member or committee of the legislature.

(b) Acceptance by two-thirds of the legislature.

(c) The question of a convention submitted to the electors.

(d) If accepted the legislature provides for the holding of the convention.

(e) Election of delegates.

(f) Meeting of the convention.

$(g)$ Work of the convention referred to the people. 


\section{Administrative Divisions}

Each State is permitted under its constitution and that of the United States to regulate its own affairs. It can make towns and counties, provide for their organization, train militia, establish courts and police, levy taxes, arrange for the education of the youth, construct buildings for the care of Administrative functions. insane, paupers, and the confinement of criminals, and build bridges and roads. In carrying out these duties and powers the State of Minnesota exercises its authority through these sets of officials, executive, legislative, and judicial. It is, however, to be noted that in practice government is administered by what we may call the Central Government and the Local Government. To each is intrusted a distinct part of the work of the State, both sharing the executive, legislative, and judicial duties spoken of above. The work of the central government is general, reaching all parts of the State, while that of the local government is confined to particular districts.

In order to conduct the business of the central government, the governor is given power to enforce the laws in any part of the Commonwealth, but to do this he relies in no small degree upon the local offgovernment. cers. On this account his executive work does not require the districting of the State, but in the creation of a legislature some organization of districts is necessary, for each part of Minnesota has the right and privilege of representation in the making of the laws. As a result we have legislative districts. The assembly constituted by the gathering of the men elected from the various localities is called a legis- 
lature, and to it belong the powers of lawmaking, Legislature. not only for the central, but also the local governments. Towns and villages may enact ordinances which are necessarily subordinate to the laws enacted by the legislature.

The judicial part of the central government is largely provided for by the constitution. Each comJudiciary. munity has its State court under the name of district courts, in which the cases arising in the neighborhood are tried. In the schedule (a part of the constitution) six districts were first mentioned in which courts were established. From time to time the growth of the State and the increase of legal business demanded changes in the number of courts. As these changes became necessary the legislature altered the boundaries of former districts until there are now eighteen. Sometimes the judicial business within the limits of a single county is so large that a county constitutes a court district. Such is the case with Hennepin and Ramsey counties.

The superior court of the central government is called the supreme court and is composed of five judges who sit at the capital of the State and hear appeals from the decisions of the district courts. When once rendered the decision of this court is final.

In a very brief and summary way we have the work of the central government before us; the local government, occupying a very large part in the problems of law and order, now demands our attention.

The divisions of local government are more numer-

Local government. ous than those of the central organization. They consist of the county, township, city, and village. 
There is no special provision in the constitution for the existence of individual counties, towns, cities, or villages, but authority is given to the legislature to create them. In fact, it can be said that the State is the creator and initiator of local government. The people are permitted to provide their own government for local affairs, but it must be in the form and manner indicated by the constitution and statutes. Thus, when the establishment of a county is spoken of, it is meant that a part of the territory of the ComThe county. monwealth has been set apart by the legislature to be in the future organized as a political community, or a quasi-corporation for political purposes. The organization of the county is a step further in advance. It is vesting in the people the corporate rights and powers to carry on the business of the division called a county. The right of the people to act in this capacity is denied until the county is fully organized as provided by the constitution and laws. ${ }^{1}$ But the formation of such a local government is a voluntary act, and may be undertaken by the people under the forms provided by the legislature.

Just what is the relation of a county to the State? The county is not a legislative district, nor a judicial one, although forming a part of these. The relation is rather fiscal and executive than otherwise. The in its relation to the State. State depends upon the county for the levying and collection of taxes, - that is, the county treasurers collect the taxes for all the political divisions in the State. Thus the people of a city, town, or village pay their taxes at the office of the county treasurer. $\mathrm{He}$ in his turn divides the money so collected among 
the different political divisions, giving part to the State, part to the town, city, or village, and retaining part for the uses and expenses of the county. The executive relation is through the office of sheriff. This officer enforces the laws of the State in the county, and is responsible to the governor for their enforcement. In turn the sheriff can call upon the governor for aid in suppressing riot and disorder. The legislative powers of the county are reposed, very largely, in the county commissioners, who are chosen by a vote of the people, as are all other county officers.

The relations just spoken of in the case of the county are not so apparent when we come to the city, village, and town. These are all local divisions, and have no direct connection with the State government, other than in the right of the legislature to make laws for their organization ${ }^{1}$ and government. These local governments may possess judicial, executive, and, to a minor degree, legislative functions. The city has a municipal court, where matters arising under the ordinances of the city are considered, and in some cases possesses a wider jurisdiction than that Judicial of a justice of the peace. The same may be said of a village, although when the village is small a justice of the peace is the judicial officer. The township is the smallest local organization, and exercises its judicial functions through a justice of the peace. These courts are original in their jurisdiction, that is, the cases which they hear originate in these courts and do not come to them from some lower court. If disagreement arises as to the decisions of the 
judge or justice, an appeal may be usually taken to the district court, and finally, in some cases, to the highest tribunal in the State, the supreme court.

The executive functions of the local divisions are numerous, but not closely connected with the central government. The constables of the townships and villages, and the police of the cities, are guardians of State property, and they also enforce State laws, but their particular business is local. The township is Executive functions of local governments. an election district when State elections occur; again, this same division is also a taxing district. In the case of a city the entire city is an assessment district, divided into small sections for the convenience of the assessors. Outside the maintenance of order, the assessment of property, and the conduct of elections, the city, township, and village have little or no general functions of government to perform. In the paving of streets, furnishing of water and light, building sewers, and guarding public health, the functions of city and town government are very important, and to this end has executive, legislative, and judicial departments.

All of these bodies have certain powers which are the same in every local division throughout the State. Within the limits of these they are free to act; but the legislature may, whenever it sees fit, alter the powers and privileges of the local bodies.

In the foregoing paragraphs the relations existing between the central and local governments have been pictured in a general way. In the next two chapters more detailed discussions of both governments will be taken up, - first the central, and second the local government.

Control of the legislature over local government.

$$
\text { government. }
$$




\section{CHAPTER IV \\ THE CENTRAL GOVERNMENT}

\section{REFERENCES}

Bryce, The American Commonzwealth, chs. xl., xli., xlii.; Wilson, The State, secs. I126-1208; Fiske, Civil Government in the United States, ch. vi.; Nordhoff, Politics for Young Americans; Dole, The American Citizen, ch. xi.; Wright, Practical Sociology, ch. vi.; The Legislative Manual of Minnesota, 1899; The General Statutes of Minnesota (the index contains references to all officers and is an invaluable aid to the study of civil government). See also Appendices $\mathrm{J}, \mathrm{L}$, and $\mathrm{M}$.

\section{The Executive}

The usual triple division of functions exists in the Division of functions. central government of Minnesota. The executive department consists of those officers who administer the affairs of the State; the legislative power rests with a Senate and House of Representatives; and the judicial power is vested in a supreme court and other minor courts.

The officers who administer State affairs may be divided into elective and appointive officers. Of the Elective and first group there are the governor, lieutenant govappointive officers. ernor, secretary of state, auditor, treasurer, and attorney general, who are elected for terms of two years, with the exception of the auditor. The other offcials are appointed by the governor for two-year terms. ${ }^{1}$

1 See Appendix L. 
The governor is the highest executive officer of the State. To hold this office he must be a citizen of The the United States, twenty-five years of age when elected, and a resident of the State one year before election. His duties are somewhat similar to those governor, qualifications and duties. of the President. When the legislature meets, which is every two years, he is to inform them by message of the condition of the State. He also acts as the commander-in-chief of the militia. In fact, the comprehensive duty of this officer is to see that the laws are faithfully executed. ${ }^{1}$

As the head of the Commonwealth, the governor possesses a number of important powers, which are put down here under four heads : (I) The Veto Power. In order that hasty legislation may be prevented, the governor, who is required to sign all bills before they become law, may withhold his signature from any bill sent to him by the lawmaking body; but the legislature may pass the bill over the governor's veto by a two-thirds vote of each house. In appropriation bills the executive may object to single items without affecting the other provisions. (2) Removals. A power of removal rests with the governor, (2) Removwhich he may exercise in the case of appointive officers and those of local administrative districts who have to do with public money, and have been, in the words of the statutes, guilty of malfeasance or non-feasance in the performance of their official duties. $^{2}$ (3) Vacancies. When vacancies occur, the governor may fill them by appointment until the next (3) Vacancies.

Powers of executive :

(I) The veto power. als. annual election. Perhaps the appointing power of

1 Constitution of Minnesota, Art. V., Sec. 4.

2 General Statutes of Minnesota, 1894, \$893. 
the governor is the largest function he possesses. With the consent of the Senate he selects the insurance commissioner, superintendent of public instruction, railroad commissioner, public examiner, adjutant general, and many other minor officers. In addition to these, the governor appoints the members of the governing bodies of State institutions and various (4) Pardon- boards. ${ }^{1}$ (4) The Pardoning Power. The usual ing power. pardoning power of the executive since I 897 does not rest with the governor alone, but is vested in a board of pardons consisting of the governor, attorney general, and the chief justice of the supreme court. ${ }^{2}$

The lieutenant governor is what might be called an Lieutenant emergency officer. His qualifications for the office governor. are the same as those for governor. The duties, however, are almost nominal. The lieutenant governor is by virtue of his office the presiding officer of the Senate. In case of a vacancy in the gubernatorial office he becomes governor.

\section{Other Elective Officers}

The executive power is supplemented by a number of elective officers. The secretary of state in order

The secretary of state. of succession stands next to the lieutenant governor. His duties are of a miscellaneous nature. He keeps the seal and papers of the State, records the papers and bonds of corporations, companies, and county officials, publishes the laws, prepares the election blanks, takes the State census every ten years, and superintends in a general way the State printing.

1 See Appendix L.

2 Constitution of Minnesota, Art. V., Sec. 4. 
An important position is that of auditor. His term of office, because more skill is required for the Auditor. duties, is four years. Two kinds of work are done by him, the regular auditing of State accounts and the superintendence of State lands. With the first group of duties go the matters of State taxes and the issuance of tax blanks and printed instructions to county officers; with the second the sale and oversight of State lands belonging to the public school fund and the university.

The funds of the State are received and distributed by the State treasurer. His duty is simple but Treasurer. arduous. An accurate account must be kept of all moneys received and paid out.

With so many interests the State needs a legal adviser. Such an officer is the attorney general, who is adviser to the State officials and the counsel of the State in suits at law. He prepares the contracts made by the State, and receives reports of the crimiAttorney nal cases prosecuted by the county attorneys in different counties, and attends to appeals in cases where the State is interested in the result.

\section{Appointive Officers}

A large number of officers appointed by the governor assist in the executive work of the State. ${ }^{1}$ These vary from insurance commissioner to custodian of the capitol. All appointive officers, with a few exceptions, hold their positions during the term of Reason for appointments. the governor. The impossibility of the mass of voters knowing anything about the qualifications necessary

general.

1 See Appendix L for Appointive Officers. 
for these minor offices makes it wise to place the appointing power in the hands of the governor.

The office of insurance commissioner was created

Insurance Commissioner.

Superintendent of Public Instruction.

Public

Examiner.

Other Officers. in 1872. His particular duty is to prevent the organization of irresponsible companies and to regulate the action of foreign companies in the State. The superintendent of public instruction fills a position of great importance. He has general supervision of the educational interests of the State. The appointment and general management of teachers' institutes rest with him, and he also acts as an adviser to the county and city superintendents. "Ex officio" he is a member of the Board of Regents of the State University, secretary of the High School Board, and a member of the Normal School Board. To each legislature the superintendent makes an elaborate report of the condition of the schools. The public examiner is the expert accountant of the State. He has almost unlimited power to examine the accounts of banks and public institutions. So important is the office regarded that the examiner is held in a bond of fifty thousand dollars. This office is an exception to the usual appointive office in that the term is three instead of two years. Besides these officers are the labor commissioner, the adjutant general, dairy commissioner, inspector of illuminating oils, State librarian, State printing expert, fire wardens, and custodian of public buildings and property.

\section{Commissions and BoArds}

A number of executive functions have been placed in the control of commissions and boards. The mem- 
bership of these boards is determined by law, the governor appointing new members from time to time Boards. as vacancies occur. The public institutions are under the charge of boards; and besides these are administrative bodies like the railroad commissioners, boards of health, equalization, charities and corrections, fisheries, and examiners appointed to examine candidates for admission to the practice of medicine, pharmacy, dentistry, law, and barbering. To the Railroad Commissioners are intrusted the regulation of charges on transportation and grain storage. The board is empowered to establish maximum rates for carrying passengers and freight, and to inspect grain at various shipping points. ${ }^{1}$ The Board of Health has to do with the public health, and, if necessary, the enforcement of the State sanitary laws, while the Board of Equalization deals with the equalization of taxes in the different parts of the State. Each board has a secretary who receives a salary, but the members of the boards themselves, except in the case of the Board of Equalization, receive no pay beyond their expenses. Thus far the board system has worked very satisfactorily in Minnesota.

\section{The Legislature}

The lawmaking body of the State consists of a Senate and House of Representatives, which meets at the capital in St. Paul every odd-numbered year. The day of meeting is the first Tuesday after the first Monday in January. The session of the legislature is limited by the constitution to ninety days, during Time of meeting.

1 General Statutes, 1894, § 379 ; Legislative Manual, 1899, p. 325. 
the last twenty of which no new bills may be introduced by members of either house except by the written request of the governor. This is done to prevent the hasty passage of bills in the last days of the session.

The membership of the two houses is quite differMembership. ent. The State is divided into sixty-three legislative districts; from each district one senator is elected. Each senatorial district elects one or more representatives, the number depending upon the population in the district. The Senate is thus composed of sixty-three members, and the House of Representatives of one hundred and nineteen. ${ }^{1}$ The terms of service also differ. Senators serve four years, representatives two. The members of the House are newly elected for each regular session of the legislature, but only one-half the senators are chosen for each regular session. The compensation of members has been fixed at five dollars per day, and fifteen cents per mile for travel to and from their places of residence.

The qualifications for membership in the legislature are about the same as those of an elector. ${ }^{2}$ Any

Qualifications. male citizen of the United States, who has reached the age of twenty-one, and has been a resident of the State one year, and of the district from which he is elected six months, may be chosen a member of the legislature. An additional restriction, however, has been placed upon senators and representatives, and that is that they may not hold, during their term, any office under the authority of the United States or the

1 Apportionment of 1899. Legislative Manual, 1899, p. I24.

2 Constitution of Minnesota, Art. IV., Sec. 9. 
State of Minnesota except that of postmaster. As to the fulfilment of these conditions, the constitution provides "that each house shall be the judge of the election returns and eligibility of its own members."

Legislation may originate in either house with the exception of bills for raising revenue, which must originate in the House of Representatives. In regard to the character of bills the constitution particularly says, "In all cases when a general law can be made applicable, no special law shall be enacted." 1

The constitution further forbids the legislature to pass any special laws relating to the affairs of local governing bodies, the property of individuals, county seats, corporations, or taxation. In addition to the prohibitions of special laws the legislature cannot grant divorces or authorize lotteries. The inhibitions of local or special laws are not to be construed to prevent the passage of general laws on any of the subjects enumerated above.

A bill in the legislative sense is a draft of a proposed law written in legal phraseology, and introduced in the legislature for its action. The method of passing upon such an act is quite complicated. Method of passing bills. (I) First of all the bill is introduced by a member or a committee at the time in the day's session set apart for this purpose. (2) Then follows its reading, which may be the reading of the whole bill or of its title only. (3) If no objections are made at this point, the bill is ordinarily referred to one of the standing committees. ${ }^{2}$ (4) When ready the commit-

Legislation and constitutional prohibitions.

1 Constitution of Minnesota, Art. IV., Sec. 33.

${ }^{2}$ For list of committees see Legislative Manual, 1899, pp. 140-143. 
tee makes its report on the bill. (5) The bill is then read a second time and referred to the committee of the whole. If the committee of the whole is favorably impressed, it is recommended that the bill "do pass." (6) It now takes a place on the "calendar" of the house for final consideration. (7) When it is reached the bill is read section by section, and put upon its passage. (8) The bill having passed the house in which it is introduced, it is sent to the other house, where the same process is repeated. (9) If the bill passes both houses, it is engrossed, signed by the presiding officer of each house, and is then sent to the governor for his signature. The governor however may veto the bill; that is, he may refuse to sign it. In such a case, he returns it with his objections to the house in which it originated. The bill is then reconsidered, and if two-thirds of the members

Veto. of each house concur in passing it again, it becomes a law in spite of the governor's disapproval. If the governor desires to veto a bill he must do so within three days from the time it is sent to him. If he does not act upon it within that time, the bill becomes a law without his signature. ${ }^{1}$ In this lawmaking machinery are many checks for the purpose of preventing hasty legislation and possible corruption. Every bill is read three times, (although the first reading is likely to be by title only,) scrutinized by a comDevices to mittee, carefully engrossed, debated, signed by both prevent hasty legislation. presiding officers and by the governor. If each officer acts conscientiously, but few objectionable bills can become laws, but the pressure of time often pre-

1 Rules of House and Senate, Legislative Manual, 1899, pp. 143144. 
vents careful consideration by the legislature or executive.

There is one class of bills that differs somewhat in method of treatment from the others. These are the appropriation bills, which may originate in either Appropriahouse. The governor, when he comes to sign such a bill, may object to any one item without vetoing the whole. If the legislature cannot pass the single item over the objection of the governor by a two-thirds vote, the remaining parts of the bill may become law; but the item vetoed remains invalid. This very wise provision was added to the constitution in 1876 in order to prevent extravagant and unnecessary appropriations. ${ }^{1}$

The legislature possesses one judicial power. This is the impeachment and trial of State officers, - a power which has thus far been exercised only three Impeachtimes in Minnesota. ${ }^{2}$ The House of Representatives has the sole power of impeachment. By a majority vote this body passes upon the charges and presents them as a sort of indictment to the Senate. The Senate acts as a court and may convict by concurrence of two-thirds of the senators present. The Senate, however, may only remove from office the persons impeached; further punishment is left to the regular judicial authorities. The members of the legislature are not regarded as officers within the meaning of the constitution, and cannot be impeached.

1 Constitution of Minnesota, Art. IV., Sec. I1.

2 In the cases of Wm. Seager, State Treasurer, 1873, found guilty; Judge Sherman Page of the Tenth Judicial District, 1878, acquitted; and E. St. Julian Cox, District Judge, 1882, found guilty. 
The system of courts.

\section{The Judiciary}

The framers of the constitution made definite provision for a system of courts. They thought it necessary to establish a power that should render justice and interpret the laws as they were made and executed. The system in this State consists of a supreme court, district courts, courts of probate, justices of the peace, and such other courts as the legislature may from time to time establish. ${ }^{1}$ Any addition to the courts provided in the constitution must be made by a two-thirds vote of the legislature.

The supreme court is the highest court in the Officers. State. It is composed of one chief justice and four associates, who are elected for terms of six years. They receive salaries of $\$ 5000$ dollars each. In addition to the judges are the clerk and reporter. The clerk is elected for four years. His duties are numerous; he files the documents and records of cases tried in the court, arranges for the publication of the judges' decisions in the newspapers, notifies attorneys and parties to causes, and performs other duties prescribed by law. The reporter's duties are very different from those of the clerk. His one work is to prepare the decisions of the court for publication in volumes of not less than six hundred pages. These volumes of reports, when printed and bound, are distributed to the judges of the district and probate courts, the university, and the State officers. Others are placed on sale for the use of attorneys and the public.

1 Constitution of Minnesota, Art. VI., Sec. I. 
The supreme court meets twice a year at St. Paul, Terms. beginning in April and October. If it is deemed necessary special terms may be held, but only after twenty days' notice in the newspapers of the State.

Next below the supreme court are the district courts. The courts under this head are not county courts, although the districts sometimes coincide with county lines. These courts, like the others, are authorized by the constitution and established by the legislature. The State is now divided into eighteen districts, each district having one or more judges, according to the amount of judicial business arising within the limits of the district. The judges of these courts receive $\$ 3500$ per annum from the treasury of the State, and in some of the districts an additional amount is paid by the county commissioners. The judges are elected for six years. These courts have general jurisdiction in civil and criminal cases.

There are two justices of the peace for each township, town, and city in the State. These officers have the power of holding court and of trying cases when Justices of the peace.

not more than one hundred dollars is involved. The justice of the peace is elected for two years and receives fees as his compensation.

The court system thus described is supplemented by the municipal and probate courts. The municipal courts are a creation of the legislature. Incorporated cities may have municipal courts, but the power District courts. of these judicial organizations depends somewhat upon the charter of the city in which they are situated. These courts possess a seal and are authorized to keep a record. The judges are elected for a term of four years and receive a salary varying with the

Municipal courts. 
Probate courts.

Notaries public.

size of the city. When a vacancy occurs in the judgeship it is filled by the city council.

The constitution provides that there shall be a probate court in each county. This court has jurisdiction in the settlement of estates and the probate of wills, the appointment of guardians, and the examination of insane persons. The judge is elected by the electors of the county for a term of two years.

A great deal of the legal business done in cities and towns must be certified to by an officer of the law. For this purpose the legislature has provided for the appointment of notaries public, who may administer oaths, take and certify depositions, acknowledge deeds, mortgages, liens, and other papers. These officers are appointed by the governor for seven years, and in receiving the appointment must pay a fee of $\$ 3$ and give a bond of $\$ 2000$. The consideration of the jurisdiction and the procedure of these courts is reserved for the chapter on the "Administration of Justice." 


\section{CHAPTER V}

\section{LOCAL GOVERNMENT}

\section{REFERENCES}

Fiske, Civil Government in the United States, chs. ii., iii., iv., v.; Bryce, The American Commonzealth, chs. xlviii., xlix.; Legislative Manual, 1899; General Statutes of Minnesota, 1894; Booth, Township Manual; Booth, Justices' Manual, 1898; Bemis, Local Government in Michigan and the Northwest, Johns Hopkins Studies, I. v.; Wilson, The State (revised edition), secs. 1209-1 259. General laws for 1895, 1897, 1899 , as published in the newspapers of the State during May of these years. These laws will usually be found in the newspaper offices in the different counties. The General Statutes, 1894, give all that is necessary previous to 1895 .

On the general question of city government such books as Wilcox, The Study of City Government, Goodnow, Municipal Problems, and Municipal Home Rule, and the last three chapters in Bryce's American Commonvealth, I., will be found valuable as supplementary to the work in the last sections of this chapter.

There has been no attempt in this chapter to set forth the details of the charters of the three larger cities. The outlines alone are given, but, whatever the charter changes, these will remain the same.

\section{The County}

The legislature of the State is the link that unites the central and local governments. The constitution vests in it the power to provide for the organization and government of counties, townships, villages, and cities. For the establishment of a county a special act of the legislature is usually required in each instance, but in the case of townships, villages, and cities, the

Local government organizations. 
people of the communities concerned take the initiative and form a township, village, or city whenever they can comply with the provisions of the general statute which governs their action. A closer examination will bring out the particular features of each.

The county is an administrative division standing between the central government and the minor local divisions. In this capacity it serves three principal purposes. The first of these is to help in the organization of the minor local divisions. The county officers are given the power to entertain petitions and to hold elections for the establishment of towns and villages.

Business of a county.

Second, the county officers act as the agents of the State in the assessment and collection of taxes, and in the apportionment of the school fund. Third, the county carries on local improvements not provided for by the smaller political divisions, such as the building of bridges, construction and repairing of roads, and erection of county buildings. The care of paupers, and sometimes of the insane, is also intrusted to the county.

As already stated in a previous paragraph, a county is organized under an act of the legislature. The constitution declares on this point that no new county shall contain less than four hundred square miles nor shall any existing county be reduced below Organization. this amount. Some of the older counties do contain less than four hundred square miles and a number of the newer organizations have as many as five and six thousand square miles. The latter, as their population increases, will probably be divided. Each new county must contain at least two thousand inhabitants. ${ }^{1}$ 
The organization of a new county may also be brought about by the petition of fifteen per cent of the resident voters. When such a petition is secured it is sent to the secretary of state at least ninety days before the general election. If the governor and auditor acquiesce in the petition, the governor, by proclamation, directs the people to vote upon the Method of question. The people having indicated their desire to form a county, the governor authorizes the county commissioners, who were provisionally elected at the same time, to proceed with the organization. This they do, providing offices and stationery and electing an auditor and other officers authorized by law.

When we come to look at the county a little more closely we find that it is a "body politic and corporate," which means that the county has both political and business functions to perform. For this purpose certain powers have been granted, such as ( 1 ) to sue and be Powers. sued, (2) to purchase and hold real estate for the use of the county and such lands as are acquired through delinquencies for non-payment of taxes, (3) to sell and convey any real and personal property when for the best interests of the people, and (4) to make contracts and to do other acts necessary to the exercise of its corporate powers. ${ }^{1}$

A county thus created under the authority of the State is governed, if such a word can be applied here, in a very large measure by a body called the county commissioners. The number of these officers depends upon the electors in the county. Where the number of voters is eight hundred or more, five commissioners County commissioners. are elected. Where the number of voters is less than 
eight hundred, three commissioners are elected. The commissioners are chosen from districts for a period of three years. The pay of these officers is three dollars for each day of their sessions and ten cents per mile going and coming from their homes to the county seat. The law which formerly limited the length of their sessions has been materially changed, and in Hennepin County the compensation in 1899 was fixed by statute at $\$ 1200 .^{1}$ The duties are numerous and varied. Among these are the choosing of grand and petit jurors, organizing new towns, townships, and counties, superintending county buildings, providing for the poor, opening roads, caring for bridges, auditing claims, publishing an annual statement of receipts and expenditures, and fixing the rate of county taxes.

The other county officers consist of an auditor, treasurer, register of deeds, sheriff, coroner, county superintendent, attorney, judge of probate, court com-

County officers.

Auditor. missioner and clerk of the district court, surveyor, physician, and overseer of the poor. To this long list of officers are intrusted the interests of the political body called a county. With the exception of the last two, who are appointed by the commissioners, these officers are elected.

The auditor is in a broad sense the bookkeeper of the county. $\mathrm{He}$ is an elective officer holding his position, like the other county officers, for two years. The State requires a bond from him of at least $\$ 2000$. In effect the auditor acts as a check

1 General Lazes, 1899, ch. 177. The commissioners of counties of less than 28,000 inhabitants may not receive pay for more than thirty-five days; in counties of greater population they may receive pay for forty days, except in counties having property assessed between $\$ 10,000,000$ and $\$ 20,000,000$, where the pay may be for sixty days. 
upon the treasurer, for every warrant must receive his signature before it is paid. $\mathrm{He}$ is also the clerk of the board of county commissioners. The salary of the auditor depends upon the valuation of the property in the county in which he holds his office. $^{1}$ The county treasurer as the custodian of the funds is one of the most important officers. In order to protect the people from any misappropriation of Treasurer. funds, the treasurer is obliged to give duplicate receipts for all moneys received, one of which must be deposited with the auditor. All of the taxes are collected by him, and in turn he apportions them to the different political divisions. Three times a year an auditing board, consisting of the county auditor, chairman of the county commissioners and the county clerk, examines his accounts. His salary is the same as that of the auditor $;^{1}$ the amount of his bond is fixed by the county commissioners.

The recording of land purchases, mortgages, bonds, trade marks and brands has been provided for by the establishment of the register of deeds. Real estate transfers may now be rated in the books of the county register of deeds by filing the papers with the date, names of owner and purchaser, and a description of the property. For the observance of his duties the register of deeds is held in a bond of $\$ 5000$ to the State of Minnesota. His salary consists of fees, except in Hennepin County.

1 No auditor shall receive more than $\$ 1200$ in counties where the property valuation does not exceed $\$ 4,000,000$, nor more than $\$ 1500$ where the valuation does not exceed $\$ 6,000,000$, nor more than $\$ 2000$ where the valuation does not exceed $\$ 10, \infty 00, \infty 00$, nor more than $\$ 2500$ where the valuation exceeds $\$ 10,000,000$. See $\$ 720$, General Statutes, 1894. 
The sheriff is the peace preserver of the county organization. His office has probably the longest history of any of his colleagues in county government. Early in English history, as the representative of the king he collected the taxes and rendered justice. The office, as the years have gone, has

The sheriff and his duties.

Salary. changed in its form and duties. Now the sheriff does not collect taxes. To-day he is the representative of the sovereignty of the people and not of a king. His duties are to keep and preserve peace in the county. In order to do this he is empowered to call upon such persons as he may think necessary to aid him. His further duties are to pursue and apprehend criminals; execute all warrants, writs, and other processes issued from a justice of the peace, district court, or other competent tribunal; to keep prisoners safely; to transport them, when necessary, to the reformatory and State prison; and conduct insane persons committed by the probate court to the hospitals and asylums. His salary is fixed by the board of county commissioners, but is paid in fees. ${ }^{1}$ In Hennepin, Ramsey, and Dakota counties special fees are allowed. The sheriff is assisted in his work by a number of deputies appointed by the board of county commissioners at three dollars per day. So important is this office regarded by the State that the sheriff is held in a bond of $\$ 5000$.

In years gone by another county officer exercised important functions, but now his duty is but a vestige Coroner. of what it once was. The coroner of to-day holds inquests over the bodies of persons who have come

${ }^{1}$ General Statutes, 1894, §§ 5551-5553. Special Lawus, 1891, ch. $373, \S 3$; ch. $426, \S 23$. 
to death by known or suspected violence. $\mathrm{He}$ is aided by a jury of six persons. The coroner receives fees for his compensation. Unimportant as his duties seemingly are, the board of commissioners is authorized to require of him a bond varying from $\$ 5000$ to $\$ 10,000 .^{1} \mathrm{He}$ is the only officer that can fill a vacancy in the office of sheriff. If the sheriff is charged with In relation to the sheriff. crime or misdemeanor, the coroner may serve a writ upon him or arrest him, if necessary.

The public school interests of the county, outside of the special and independent districts, are looked after by an officer called the county superintendent of schools. He is expected to visit the schools in the county, to examine and license teachers, and to advise and consult with the various local boards of education. Under his supervision at least one institute for the instruction of teachers must be held in the county each year. The State superintendent of public instruction receives from the various county superintendents reports and statistical matter relating to the schools. The remuneration of this officer depends upon the number of common school districts in the county. He receives at least ten dollars for each district, but in no case more than $\$$ I 800 for his services during the year.

Besides the judges and justices of the peace there are two judicial officers in each county, the attorney and the court commissioner. The first of these officers serves as a legal adviser to the commissioners and Attorney. other county officers. When the county is a defendant in a case he acts as counsel; he also appears as prosecutor when the State brings a criminal action in

\section{County}

superintendent. 
that county. He draws all bills of indictment and presentment found by the grand jury. During each year the county attorney sends to the attorney general a report of the criminal cases tried in the county. The office held by the county attorney is very important in that the protection and defence of the rights of the community rest in no small degree in his hands. The remuneration he receives is fixed within the provisions of a general law by the commissioners of each county.

The fact that the district courts do not remain constantly in session demanded, in the opinion of the

Court commissioner.

Other officers.

Removal of county officers. makers of the constitution, a court commissioner who should exercise the powers of a district judge at chambers. ${ }^{1}$ He is empowered to grant writs of habeas corpus, and attachments, and to issue warrants. In the judicial districts in which there is more than one county, this office becomes important in keeping up the machinery of justice in those counties where no district judge resides. The term of office is four years, the remuneration is by fees, and a bond of two thousand dollars is required.

In addition to the county officers already enumerated, there are several others, including the county physician, the overseer of the poor, and the surveyor. The last officer is elected for two years, the others are appointed by the commissioners.

Experience has taught the makers of constitutions and laws that provision must be made for the removal of those officers who violate their trusts. In Minnesota this power has been placed in the hands of the governor, who may remove from office any clerk of

1 Constitution of Minnesota, Art. VI., Sec. 15. 
the supreme or district court, judge of probate, court commissioner, sheriff, coroner, auditor, register of deeds, county attorney, superintendent of schools, commissioner, treasurer, or any collector or receiver or custodian of public moneys, when evidence is sufficient to show that such officers have neglected their duty or have been guilty of malfeasance. ${ }^{1}$

\section{The Township}

The township in Minnesota, geographically, is an area of land six miles square. Upon this survey has been built the political body we call a town. It is interesting to note how the geographical form of the organization came into existence. At the suggestion of Thomas Jefferson, in 1785 , Congress passed a land ordinance, one of the provisions of which included the present system of government surveys. A line running north and south is marked out, called the principal meridian. Twenty-four of these have been established, beginning with the line between Ohio Township survey. and Indiana, and extending to the last one near Portland, Oregon. On each side of the principal meridians range lines six miles apart are laid off and numbered east and west from the meridian. At right angles to these are drawn others parallel to a true line of latitude. These also serve as east and west base lines. North and south of the parallel are drawn township lines six miles apart. Thus by this simple system the western township has come to be as nearly as possible an area six miles square. ${ }^{2}$ Each

1 General Statutes, 1878, ch. 9, §3; 1881, ch. 21, §1.

2 Fiske, Civil Government, 81-83. 
township, in its turn, is divided into thirty-six sections, containing six hundred and forty acres each; a further division is made by dividing each section into halves and quarters, so that it is a very easy matter to describe and register land. ${ }^{1}$

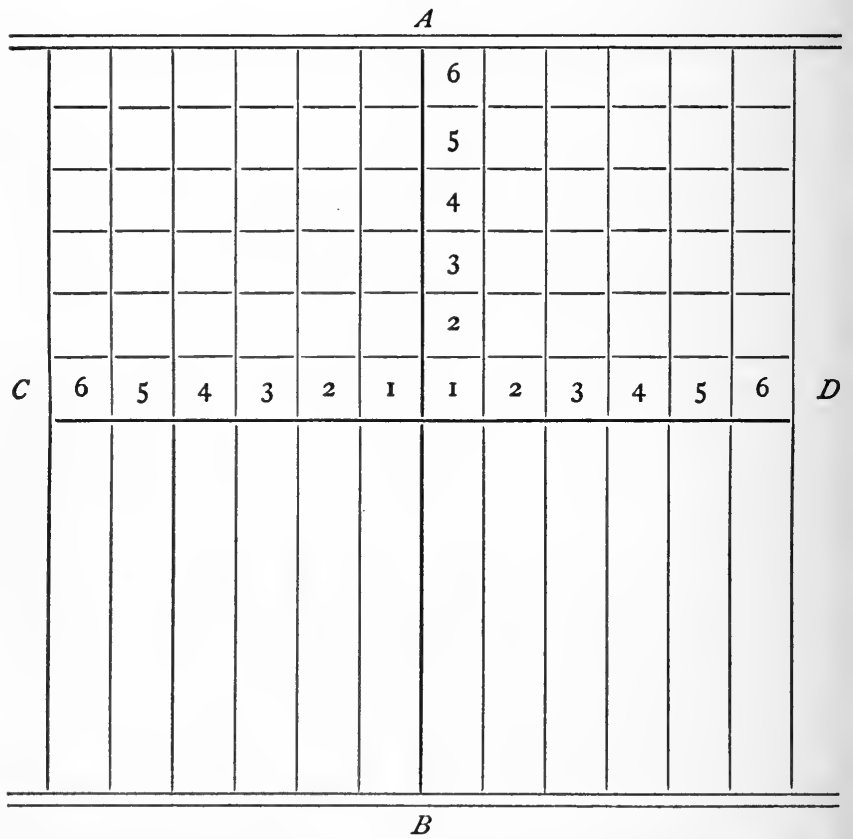

$A B$, principal meridian.

$C D$, principal parallel or base line.

As a political organization the town is one of the

Political organization of the township. oldest forms of government. In almost prehistoric times the scattered peoples in the forests of Germany and England met in assemblies to discuss the affairs of their tribes. To-day, in the township, 
the electors assemble annually to consider various matters of business. In relation to the county the township is a mere administrative division; but as a part of the larger idea of democratic government it is really the basis of the system, for it is certainly in the annual town meeting that the people have learned to govern themselves. The duties of this organization, although not numerous, are important. The town has to do with roads, restraining of cattle, the care of the poor, and the condition of fences. Necessarily, with these duties go the levying of local taxes and the election of town officers, such as supervisors, clerk, treasurer, overseers of highways, assessor, constables, and two justices of the peace. ${ }^{1}$ By law, the meeting where all these matters are considered is held on the second Tuesday in March. The township is the unit for elections - and is sometimes divided into voting precincts.

Before the duties spoken of above can be carried out, an organization must be effected, by which the congressional township becomes a political body with an authorized government. The legislature has provided the machinery for the transformation. ${ }^{2}$ Whenever a majority of the legal voters of any congressional township containing twenty-five legal voters petition the board of county commissioners to be Petitions to the county commissioners. organized as a town, the commissioners shall proceed to fix the boundaries, and give a name to the same. Any report made by the commissioners on the proceedings is to be filed with the county auditor, who shall within thirty days send this report 
to the State auditor. A number of other provisions are made in the same law to change the name or boundaries when deemed necessary. Thus, when a meandering stream divides a township, making it inconvenient to do township business, one portion may be attached to the adjoining township whenever two-thirds of the voters in the fractional parts petition for it. ${ }^{1}$ The electors, in these instances, must possess all the qualifications of voters in county or State affairs.

The powers of a town are similar to those of the county. Each town may sue or be sued, purchase and hold lands subject to the control of the legislature, make such contracts as may be necessary, Powers of the and dispose of and regulate the use of the corporate township. property of the town. The business of the town is placed in the hands of three supervisors. These men have general control over the town affairs, but are subject at all times to the action of the town meeting. The supervisors constitute a board of health, and have the power necessary to preserve the public health. $^{2}$ The accounts which are payable by the town are subject to the auditing of the supervisors. Occasionally vacancies occur in the list of the town officers; these may be filled by persons selected by a majority of a board consisting of the three supervisors and two justices of the peace.

The township officers hold their positions for one

Terms and compensation of officers. year, with the exception of the justices of the peace and the constables, who are elected for two years. The compensation is moderate. The town assessors 
receive $\$ 2$ per day, the town clerk and supervisors $\$ 1.50$ while attending to business in the town, and $\$ 2$ when outside of the town, but no supervisor shall receive more than $\$ 40$ in a year for his services. The town clerk may be paid fees for his services. ${ }^{1}$

\section{The Village}

Previous to the constitutional amendment of 1896 the legislature incorporated villages by special laws. ${ }^{2}$ The amendment provides that any town or city may frame its own charter, but this right is restricted by Organization the legislature in that a village containing less than one thousand inhabitants cannot possess what is called a city government, but must retain its village organization, the principal difference being in the office of mayor and the powers of the council. A village which is unincorporated is in every sense a part of a town, and has the government of that body; but any district, section, or part of a section not already incorporated, which has been platted into lots and blocks, providing there is a resident population of one hundred and seventy-five, may become incorporated as a village. When thirty of the inhabitants petition the county commissioners, an election shall be held for the purpose of determining the question of incorporation. If the result is favorable to such action, the commissioners file the certificate of election, together with the petition, in the office of the register of deeds of the county. The

1 General Statutes, 1894, §1003; General Laws, amended, 1895, ch. 13.

2 Constitution of Minnesota, Art. IV., Sec. 36. 
village is then incorporated, and becomes a separate election and assessment district. ${ }^{1}$

The organization of village government takes place when officers are elected. The elective officers are Officers. a president, three trustees, a treasurer, recorder, two justices of the peace, and a constable. With the exception of the last three officers the term of office is one year. The justices and constable are elected for two years.

The president, the three trustees, and the recorder constitute the village council. Under legislative re-

Powers of the village council. strictions they are permitted to make ordinances for the government of the village. The council appoints a street commissioner, village attorney, pound master, sextons of the cemetery, fire wardens, and a special policeman. The council may also establish a fire department, library, board of health, markets, and waterworks, and is given the power to provide for the licensing of amusements, the levying and collecting of taxes, the plotting of parks, streets, and alleys, making and repairing of sidewalks, and whatever is necessary for the better administration of the village.

A great many villages have been granted charters by special legislative act, but this was prior to I89I, and in some instances even to 1883 ; since that time, a number of laws have been passed classifying the villages and unifying village government. Thus the legislatures of I89I and I895 thought it wise to provide an organization for the larger town. It was found that the village government of a small place was hardly sufficient for a village of two or three thou-

1 General Statutes, 1878,2 , ch. 10, § $212 ; 1885$, ch. 145, § 9. 
sand inhabitants. The legislature in 1891 placed the number of inhabitants at three thousand for a town that was to enjoy the privileges of a larger two and three thousand organization. ${ }^{1}$ The amendment of 1895 reduced this class of number to two thousand, but no difference was made in the organization. ${ }^{2}$ The villages of three thousand inhabitants are divided into at least four wards, those of two thousand into two wards. Each ward is an election district.

The elective officers of the larger villages are the same, with the exception of the judge, as those of the incorporated but smaller villages. There are the president, recorder, assessor, treasurer, and two trustees for each ward, and a municipal judge. The president is the executive officer of the village and officers. the chairman of the council. It is his duty to see that the laws of the State and the ordinances of the council are observed and enforced. He possesses the power of veto over the action of the council. This body passes the ordinances necessary for good order and the regulation of fire department, police, parks, waterworks, public health, and other matters related to the welfare of the village. The power to Powers of the council. levy an annual tax for village purposes upon the property within the village belongs to the village council.

One of the institutions the village of this class enjoys over the smaller organization is a municipal court. The judge of this court is elected for two years, receiving as a remuneration from $\$ 100$ to $\$ 1500$ Village court. a year, depending upon the decision of the council. ${ }^{3}$

1 General Statutes, $1894, \S$ I 302.

${ }^{2}$ General Laws, 1895, ch. 69.

8 Ibid., 1897, ch. 237. 
The judge also acts as a clerk of the court ex officio. ${ }^{1}$ By this arrangement the duties of the recorder are reduced to the keeping of the records of the council and deeds and contracts relating to village affairs, and occasionally examining the books of the treasurer. ${ }^{2}$

In 1896 the constitution of the State was amended, granting the right to any city or village of a thousand inhabitants or over to frame its own charter within the general laws provided by the legislature. In time such a right will lead to greater uniformity in village government. ${ }^{3}$

\section{Cities}

The cities of Minnesota have struggled for a number of years to secure home rule. In I89I special legislation concerning their government was stopped; two years later a model charter was passed by both houses and vetoed by the governor. In I 895 the city attorneys of the three largest cities framed a charter which failed to pass. An amendment to the constitution was proposed by the legislature in this year, and accepted by the people in 1896 . The amendment, however, proved defective, but was modified at the next meeting of the legislature and ratified by the people in 1898 . Under this amendment any city or town of a thousand inhabitants or more may frame its own charter.

The machinery for framing a charter is set in motion in two ways : (I) by the judges of the district court, who appoint commissioners at their own volition; or (2) on request of ten per cent of the legal

1 General Laws, 1878 , ch. 84 . 2 See ch. vii.

${ }^{8}$ Constitution of Minnesota, Art. IV., Sec. 36 . 
voters. The board consists of fifteen freeholders who have been qualified voters in the city or town for the last five years. The board serves for four years, and must submit to the people a charter, signed by a majority of the board, within six months after appointment. ${ }^{1}$

The next step is the submission of the charter to the electors. This must be done at the next general election or at a special election. In order that the Submission of the charter. provisions of a new charter may become law, it is necessary that four-sevenths of all the electors voting at the election shall vote in favor of the charter. If the result of the election is favorable, the certificates showing the vote are signed by the mayor, and deposited in the office of the secretary of state and in the archives of the city. ${ }^{2}$

The constitutional amendment provides also for the alteration of a city charter by the charter commission. The commissioners may, after thirty days' The election. notice through the newspapers, present an amendment to the people, but before such an amendment

${ }^{1}$ See General Lawes, 1899, ch. 351 .

2 Steps in securing a charter: -

I. Petition to judges.

Signed by ten per cent of qualified voters.

2. Appointment of commissioners.

3. The framing of the charter.

4. Submission to voters.

5. Amendment.

At the volition of the judges of the district court, or on request of petitioners.

$\left\{\begin{array}{c}\text { Must be accepted by four- } \\ \text { sevenths vote. }\end{array}\right.$

Presented by commission or at request of five per cent of the people. Must be accepted by three-fifths of qualified voters. 
can become a law it must be accepted by three-fifths of the qualified electors. The insufficiency of this method was recognized in 1898 , when the constitution was so changed that any proposed amendment sustained by a petition signed by five per cent of the voters might be submitted to the people. The objection to the first method was its lack of democratic and representative spirit.

For the purposes of legislation the same amendment to the constitution divides cities into four classes as follows: those over fifty thousand inhabitants, those between fifty and twenty thousand, those not less than ten thousand, and those less than ten thousand inhabitants. The legislature may, without violating the constitutional clause against special legislation, pass laws that will apply only to the different classes of cities.

The legislature of 1895 provided by general law

The general law of 1895 .

a form of charter which might be accepted in lieu of one made by a charter commission; so that a city not wishing to go into the doubtful experiment of charter-making might be incorporated under the form provided by the State. ${ }^{1}$ But even when a charter is made by a city the general regulations laid down in the law of 1895 must be conformed to. Under this law a city of over fifteen thousand may be incorporated by a majority vote of the qualified electors residing in the city. Before this incorporation can take place the inhabitants must signify their desire to be so governed by presenting a petition describing the territory. The petition is then filed in the office of the county commissioners, who an- 
nounce an election, and, upon canvass of the returns, if favorable, issue certificates which are filed in the offices of the register of deeds for the county and the secretary of state. ${ }^{1}$

The act also provides for the division of cities into wards. Cities of more than thirty thousand population are required to have not less than ten nor more than fifteen such divisions; cities possessing less than thirty thousand population may have not more than ten wards. The city council determines the division of wards and their boundaries; any change in the ward boundaries can be made but once within a period of five years and then only by a two-thirds vote of the council. The wards are the basis of the council Ward membership. Under the law of 1895 there are two groups of aldermen; - those elected from the ward, and those elected at large. The first number are from each ward, the second vary with the size of the city. Thus in cities of six wards or less two aldermen are elected at large; in cities having ten or more wards eight aldermen are elected at large. Cities organized previous to this law under special act or charter do not conform to this method of electing members of the council. Minneapolis at the present time elects two members of the council from each ward. Should she adopt a new charter it would of necessity conform to the law of 1895.

The salaries of all the officers of a city are regulated by legislation; occasionally cities secure special legislation in the form of a general law permitting them to pay more for the services of an

1 For officers see Appendix P. 
Salaries of aldermen.

Powers of the city council.

officer. ${ }^{1}$ Ordinarily the compensation of aldermen, in cities exceeding thirty thousand, may be as high as $\$ 500$; in cities between this number of inhabitants and fifteen thousand, $\$ 300$ is the limit. Below fifteen thousand, \$roo dollars may be paid.

The organization of the council takes place biennially on the first Tuesday after the first Monday in January. The officers, consisting of a president, vicepresident, and secretary, are elected by ballot. The council after it is once organized meets once a month and transacts the business of the city, such as the making of ordinances, the awarding of contracts, the drawing of warrants, and the appointment of a city clerk, attorney, engineer, fire chief, and other officers. In addition to these powers the council may authorize the issue of bonds to incur an indebtedness for public buildings and improvements, levy taxes, condemn property, provide for bridges, docks, light, water, streets, sidewalks, and many other necessary things. In every city are street car companies, telephone, telegraph, and gas companies, which must be regulated and prevented from encumbering streets with their wagons, poles, tracks, and pipes. The city council has the power to pass ordinances for the

1 Maximum salaries permissible by law, General Laws, $1895, \mathrm{ch} .8$. The maximum salaries per annum of the following officers are : Mayor, $\$ 3000$; private secretary, $\$ 1200$; treasurer, comptroller, city clerk, city attorney, and city engineer, each $\$ 4000$; secretary of the board of water commissioners, $\$ 2000$; superintendent of the same department, $\$ 1800$; commissioner of health, $\$ 2400$; building inspector, $\$ 1800$; chief engineer of the fire department, $\$ 2500$; first assistant, $\$ 1500$; second assistant, $\$ 1200$; chief of police, $\$ 2500$; the judge or judges of the municipal court, $\$ 3000$; clerk of the court, $\$ 1800$; superintendent of the workhouse, $\$ 2500$; and the commissioner of public works, $\$ 2000$. 
proper observance of the laws of hygiene, the regulation of saloons, and the suppression of vice. The enforcement of these laws constitutes the principal duty of the mayor and the police department.

The executive department of a city consists of a mayor and a number of subordinate officers. The treasurer, and, in cities over thirty thousand, a comptroller, and justices of the peace, are elected by the executive. people; but the clerk, attorney, street commissioners, engineer, weigh master, and assessor are elected by the council. The members of the police department and the board of public works are nominated by the mayor. Over these officers the council has the power of removal by the presentment of charges and a twothirds vote sustaining the charges.

The mayor is the chief executive of the city. It is his duty to enforce the laws of the State and the ordinances of the city through the help of the department of police. The mayor has a very definite The mayor. relation to the council. From time to time he is to inform this body concerning the affairs of the city. The law requires that every ordinance passed by the council must receive the signature of the city executive before becoming a law. If the mayor vetoes an ordinance it may become a law over his negative, providing it receives a three-fourths vote of the council. An occasional act of the council requires a threefourths vote to make it legal, and in such a case the mayor's veto can be overcome only by a unanimous vote. When the mayor refuses to sign a resolution or ordinance extending the bonded indebtedness of the city the decision is final. The mayor is not allowed to sign any ordinance, order, or resolution 
until four days have passed, and if not returned within ten days the ordinance, order, or resolution possesses the same force as though signed by him.

The city executive appoints the chief of police and all patrolmen, the commissioner of health, the superintendent of the workhouse, and the members of the library and park boards. The executive is usually a member ex officio of the several boards; just what these are is determined by the city itself.

The comptroller and treasurer are clerical and fiscal officers. The first deals with the bookkeeping, warrant accounts, countersigning of bonds, examination and auditing of accounts and claims; while the second receives the moneys of the city, keeps accounts, Comptroller and apportions the receipts to the various funds under and treasurer. the direction of the council. To insure the safety of the finances and the responsibility of the treasurer he is required to give a bond equal to twice the amount of money likely to be received by him during the fiscal year. A further check is secured by requiring the comptroller to sign all warrants before they can be legally cashed by the treasurer, the payment of the warrants having first been authorized by the city council. The statutes of the State and the ordinances of the city are full of detail in relation to the work of the treasurer and comptroller in the expectation of guarding the public funds against possible corruption or actual theft. ${ }^{1}$

Another feature of city government is the boards, the most important of which are the education, library, Boards. and park boards. The first of these will be treated in the chapter on "Education"; the duties of the other 
two are sufficiently indicated by their title. Unless otherwise provided in the charter the mayor appoints the members of the park and library boards. It has become quite necessary to include in a charter some plan for civil service. This has been done in the law of 1895 . Under its provisions a city council may appoint from three to five experts to examine assistant engineers, inspectors and their assistants, and clerks for department positions. The basis for promotion Civil service. is the knowledge and efficiency of the candidates. The city council is also authorized to provide books for the registration of laborers who desire employment on city works. In selecting men for work, they are usually employed in the order of registration.

Many points concerning city officers have necessarily been omitted in a chapter like this, but matters relating to the collection of taxes, the conduct of justice, and the management of education will be left for consideration in later chapters. Our review of local government would hardly be complete without some reference to the charters of the three larger cities.

\section{MinNEAPOLIS}

The city of Minneapolis had its first beginnings as St. Anthony's Falls in I849. On the west side of the river another settlement sprang into existence which was christened Minneapolis in $1854 .^{1}$ Four years later the newly christened city was vested with its first town government, but it did not assume the form of a municipality until 1867 . The two thriving towns

Origin of the city.

1 The name was suggested by Mr. Charles Hoag of the city, who died in 1888 . 
situated on opposite sides of the same river found their interests would not be endangered by a union, and so in 1873 St. Anthony's Falls was united with Minneapolis under the latter name.

The present charter of Minneapolis was adopted in 1873 by a special legislative act and has been modified and revamped from time to time by the legislature. It may be called a council form of charter, that is, the principal powers of government are vested in the council. The elective officers are a mayor, treasurer, comptroller, municipal judge, justices of the

Officers and terms. peace, members of the city council, and the members of boards. The mayor, treasurer, and comptroller hold office for a period of two years. There are two aldermen from each ward, elected for a four-year term. The salary of an alderman is $\$ 500$ per year. The city is divided into thirteen wards, which makes the city council a body of twenty-six persons. This body appoints the city attorney, engineer, assessor, clerk, chief of fire department, and minor officers. On this point the charter says, "All other officers necessary for the proper management of the affairs of the city shall be appointed by the city council unless otherwise provided in this charter." 1 The powers of the council are extensive and include the appropriation of money, paving of streets, and the supervision of the various departments of the city government.

The schools, library, parks, health, and charity are under the supervision of boards. The board of education is composed of seven persons who are elected Boards. for a term of six years. They are so chosen that their terms do not expire at the same time, and hence the

1 Charter of Minneapolis, I888, ch. II., § I. 
board is a continuous one. The library board consists of nine persons, six of whom are elected for the same period as the members of the board of education. The other three (the mayor of the city, the president of the board of education, and the president of the State university) are members ex officio. The term of service of the park board is six years. Fifteen members constitute this body. Three of them are $e x$ officio members, the mayor, chairman of the council committee on roads and bridges, and the chairman of the council committee on public grounds and buildings. The affairs of the waterworks department, workhouse, fire department, police, public health, and hospitals are directed by committees of the council. ${ }^{1}$

The present charter has been modified and amended many times, but the difficulty in securing legislative action has made it inadequate to the requirements of a growing city. An attempt was made in 1898 to frame a new charter, but without success. A new charter commission was appointed in January, 1900, but its work was largely confined to the remodelling of the work of the commission of I898. The commission's charter failed of passage by an overwhelming vote.

\section{St. Paul}

This city is named after the chapel of St. Paul, established in 1839 on the banks of the Mississippi. In 1854 the town built about the chapel was incorpo-

1 It is very difficult to get a satisfactory copy of a Minneapolis charter. There is a book containing the charter up to 1888 , published by Harrison and Smith of the city. The city publishes, each year, a volume of reports. It may be had by application to the city clerk. 
The charter sperience.

Elective officers.

The mayor.

rated as the city of St. Paul and was given a special charter. From time to time this charter has been modified. The constitutional amendment of 189 I prevented any further special legislation, and since that date the people of the city have been trying to secure modifications of the charter. Under the charter commission act another effort, which was successful, was made in the spring of 1900, the people accepting the work of the commission. The present charter is a mixture of the federal and board types, the mayor appointing the members of the several governing boards, while the latter regulate and govern the affairs of the city in many of its departments. The elective officers under the charter of 1900 are the mayor, city comptroller, two judges of the municipal court, two constables, and the city council. In the council rests the power of removal by a two-thirds vote.

The mayor is elected for a term of two years at a salary of $\$ 2500$. He appoints the board of school inspectors, fire commissioners, water commissioners, park commissioners, library board, board of public works, commissioner of health, chief of police, and the directors of the workhouse. The power which the executive wields through these appointments is very important. As an executive officer the mayor has oversight of the city officers and boards. The usual provisions are made in the charter for the signing of ordinances, vetoes, and for advising the council by message. ${ }^{1}$

1 An excellent compilation of the municipal code of St. Paul was published in 1893 . The reports of the city departments may be had in limited number, by applying to the city clerk. The boards and officers are enumerated there. See also, for the history of St. Paul, The Pioneer Press, November 9, 1899. 
The common council is a bicameral organization consisting of a council and an assembly. The assemblymen are elected at large from the city, although certain restrictions are placed upon residence to prevent too large a representation from one section. The aldermen are elected one from each ward. The present membership of the council is twenty, eleven aldermen and nine assemblymen. On

Membership of the certain occasions, as in the election of a city clerk, the two bodies act in joint session. The salary is \$100 per year and the term of office two years.

The powers of the city council pertain to the management and control of the finances and property of the city, and the passage of ordinances relating to Powers of city council. government, order, suppression of vice and crime, issuance of licenses, paving, roads and bridges, and many other matters requiring regulation. The council elects only the city clerk, attorney, building inspector, and market master. The city treasurer, comptroller, and clerk perform the duties set forth in the section relating to the general government of a city. ${ }^{1}$

The St. Paul charter provides for an unusual number of boards, whose members are appointed by the mayor. Nearly all of these boards serve without compensation, and undoubtedly give good service, guarding the finances and expenditures fairly well. The boards have already been enumerated. With the Terms of exception of the boards of water commissioners, park commissioners, and the directors of the workhouse, whose terms are for five years, the regular period of service is three years. 


\section{Duluth}

Charter history.

Officers.

Elective officers.

The city of Duluth has struggled for a number of years to secure a new charter, and has finally succeeded in doing so. Commissioners were appointed under the constitutional provisions to frame a continuous and complete charter, but it was not until the spring of 1900 that such an instrument was actually accepted by the people. Many legislative acts had been passed to modify the old charter. The constitutional amendment of 1892 prevented any further legislation, and the citizens were thrown on their own resources. After much opposition a new charter was framed and accepted by the people.

The Duluth charter may be described as an extreme form of the mayor type, in that the common council has almost no appointive powers. In the matter of appointive officers, the mayor is allowed to name all police officers, the members of the board of fire commissioners, public works, light and water commissioners, civil service commissioners, and the park and library boards, assessor, city attorney, health officer, city engineer, and building inspector. $\mathrm{He}$ also has the right of veto subject to the usual restrictions upon that power. The city council in turn appoints the city clerk and a few minor officers.

The elective officers of the city are the mayor, treasurer, comptroller, aldermen, municipal and special municipal judges. With the exception of the last two, who hold their offices for three years, the terms of office are two years. The aldermen number two from each ward and form the common council. This body fixes the salaries of minor city officers, passes 
such ordinances as are necessary for the proper government of the city, and may remove officers upon proper evidence.

Three important boards are mentioned in the char- Boards. ter, the board of fire commissioners, the board of public works, and the park board. The first board is named by the mayor and elected by the council. It consists of three members appointed for three years. The compensation is $\$ 200$ per year. The board has full control of the fire department. Public works are always a part of a city's business. In Duluth the matters of streets, public buildings, and paving are placed under the control of a board of three persons holding their offices for three years. The board passes upon contracts, and superintends the paving, sewers, and building within the city. The salary of the members of this board is $\$ 1000$ a year. The third board is the park board. The membership consists of three persons appointed by the mayor. Three years is the term of office.

The power of removal of any officer or member of Removal. the boards rests with the city council, providing there is a two-thirds vote to sustain the charges that may be brought against an officer.

The charter also provides an elaborate system of municipal ownership when desired by the people. The sale of public franchises is forbidden until the terms are published in the newspapers for six weeks. The council is limited in the granting of franchises to a period of twenty-five years. The regulation of the rates for public service is left in the hands of the council. The charter is an experiment, but embodies some of the latest ideas in municipal government. 


\section{CHAPTER VI \\ NOMINATIONS AND ELECTIONS}

\section{RefERENCES}

Bryce, The American Commonwealth, II. chs. lix.-lxix.; General Statutes, 1894 (see index under Elections); General Laws of 1895, 1897, 1899; Booth, Township Manual, Minneapolis, 1899; Legislative Manual, 1899, index.

\section{Who ARE Voters}

The franchise.

A man may vote in some States and still not be a citizen of the United States, but this is not true in Minnesota. The question of franchise and the restrictions upon its exercise are determined by the States under the authority of the Federal Constitution. Thus one State may require voters to live within its boundaries one year, another but six months; in all cases, however, the voter, if not already a citizen of the United States, must have signified his intention of becoming one. ${ }^{1}$ But the States may remove even this slight qualification if they choose. The privilege of the franchise in Minnesota is not as easily acquired as in earlier days. The constitution has been amended

1 In reference to this point, see articles on "Citizens" and "Naturalization" in Johnson's Cyclopadia, and Bryce, The American Commonzuealth, I. 419. 
from time to time, changing the conditions of residence, and making it more difficult to become an elector. In November, 1896 , the last amendment was ratified, granting the privilege of voting to citizens of the United States alone.

On the subject of franchise and the rights of voters the words of the constitution present the matter concisely and to the point.

"Every male person of the age of $2 \mathrm{I}$ years or upwards belonging to either of the following classes who has resided in this State six months next precedClasses of voters. ing any election, shall be entitled to vote at such election in the election district of which he shall at the time have been a resident for thirty days, for all officers that now are, or hereafter may be, elective by the people.

"First - Citizens of the United States who have been such for the period of three months next preceding any election.

"Second-Persons of mixed white and Indian blood, who have adopted the customs and habits of civilization.

"Third - Persons of Indian blood residing in this State, who have adopted the language, customs, and habits of civilization, after an examination before any district court of the State, in such manner as may be provided by law, and shall have been pronounced by said court capable of enjoying the rights of citizenship within the State." 1

Another group has been admitted to the franchise on particular questions. Women who comply with

Women voters.

1 Constitution of Minnesota, Art. VII., Sec. I, amended November 3,1896 . 
Restriction of the franchise.

the same conditions as the male voters may vote upon matters relating to schools and libraries and may participate in the election of officers having them in charge.

Residential restrictions have been placed upon voters by the constitution, making it necessary for a citizen of the United States, either native born or naturalized, who has been living in another State, to reside in Minnesota six months previous to the election before he can vote. ${ }^{1}$ Even a citizen of the State cannot vote in an election district unless he has lived in it at least thirty days next preceding the election. These restrictions are necessary to good order and pure elections. The election law of the State has also decreed that persons convicted of treason or felony, or who are under guardianship, or are insane, shall be excluded from the franchise.

We now have pretty well before us the qualifications necessary for citizenship. The whole matter may be made somewhat clearer by the following schedule.

1 In reference to the question of United States citizenship as a requirement for voting in the State, a very interesting point was raised in the case of the mayor-elect of Redwood Falls. This officer was elected under the impression that he was a United States citizen. It was found that the mayor was born in Canada and that he was but five years of age when his father moved to Minnesota Territory. The father failed to take out the "second papers" necessary to full United States citizenship. The attorney general to whom the question had been referred decided that any foreign-born elector who was in the Territory of Minnesota at the time it was admitted to statehood was a full citizen of the State, on the ground that the action of Congress in admitting Minnesota to the Union was tantamount to a collective naturalization of the citizens of the Territory. 
Conditions of Suffrage in Minnesota

\begin{tabular}{|c|c|}
\hline Persons & Qualifications \\
\hline $\begin{array}{l}\text { Males } \\
\text { Natives of the United States. } \\
\text { Foreigners who have been natu- } \\
\text { ralized. }\end{array}$ & $\begin{array}{l}\text { Age } 2 \text { I years and upward. } \\
\text { Residence } \\
\text { In the United States five years. } \\
\text { In the State six months. } \\
\text { In the election district thirty } \\
\text { days. Status }\end{array}$ \\
\hline $\begin{array}{l}\text { Civilized Indians who have been } \\
\text { examined. Women } \\
\text { Belonging to either of the classes } \\
\text { described above may vote upon } \\
\text { measures relating to schools and } \\
\text { libraries. }\end{array}$ & $\begin{array}{l}\text { Not convicted of treason or } \\
\text { felony. } \\
\text { Not under guardianship. } \\
\text { Not insane. } \\
\text { Women } \\
\text { The same as those of the male } \\
\text { voter. }\end{array}$ \\
\hline
\end{tabular}

\section{Nomination of Candidates}

There are two methods of nominating candidates for office: first, by convention, which includes the machinery of the primary; and second, by petition. ${ }^{1}$ The convention method is the usual way of selecting party candidates for office.

The organization of a nominating convention is preceded by the election of delegates by the various primaries in the city, town, county, or congressional district. The law of 1895 provides that any political party may hold primary elections in any county or Primaries city in the State. ${ }^{2}$ The political parties in the State called.

1 "A primary is a meeting of voters belonging to the same political party in a ward, township, or other election district, held for the purpose of nominating candidates for office or choosing delegates to a convention. Theoretically, every voter belonging to a party in a district has a right to attend the primary and vote." - Century Dictionary.

2 General Laws, 1895, ch. 276. Methods of

Schedule of Suffrage.

Nomination. 
have what are known as committees, one for the State, and one for each county and city and sometimes township. These bodies have the oversight and management of a party's affairs. Thus the State central committee has general charge of the campaign throughout the State, the county committee looks after the interests of the party in the county, and so on down the line until we come to the voting districts (which in cities of over two thousand must not contain over four hundred voters), where we find a committee that has charge of the party's affairs in the district. The chairman of the district committee, or

Notice of primary. better the precinct committee, must see that notices are posted of the coming primary election at least twenty days before the event. In this notice appear the date, place, hour, and number of delegates to be elected. The call for the primary is signed by the chairman and secretary of the larger committee that has the election in charge. The precinct committee carries out the instructions issued by the county, congressional, or city committees. The notice of the Republican Congressional Convention given below illustrates the system. ${ }^{1}$

\section{REPUBLICAN CONVENTION AND PRIMARY ELECTION OFFICIAL CALL}

A Republican Convention for the Fifth Congressional District, State of Minnesota, will be held on Wednesday, the 25th day of May, 1898 , at Harmonia Hall, corner of Third Street and Second Avenue south in the City of Minneapolis.

Said Convention shall convene at Io o'clock in the forenoon of said day, for the purpose of nominating a candidate to represent the Fifth Congressional District of the State of Minnesota in the Fifty-sixth Congress, to be voted for at the next general election, to be held November 8,1898 , and for the transaction of such other business as may properly come before the Convention. 
The primary having been called, and the hour of the meeting at hand, the chairman or secretary of

The basis of representation in said convention shall be one delegate for each fifty votes, or major fraction thereof (twenty-five being for the purpose hereof treated as a major fraction of fifty), cast for the head of the presidential electors at the last election held November 3, 1896, in each election precinct, each precinct being entitled, however, to at least one delegate.

In accordance with the above apportionment, the several election precincts in Hennepin County will be entitled to the following number of delegates in said convention :-

\section{COUNTRY}

Bloomington ................ 3 Minnetrista ................ 2

Brooklyn .................... 4

Champlin ................. 2

Corcoran ................... 3

Crystal Lake ................ 2

Dayton ................... 2

Eden Prairie................ 2

Excelsior town and village ..... 4

Greenwood ................. 2

Hassan ................... I

Independence .............. 2

Maple Grove ................ 3

Medina ................... I

Minnetonka ................ 3
Orono ...................... 2

Plymouth ................... 2

Richfield .................... 3

St. Anthony ................ r

Village of Edina ............. 2

Village of Golden Valley ........ 2

Village of Minnetonka Beach .... I

Village of Osseo .............. I

Village of Robbinsdale ......... I

Village of St. Louis Park ....... 4

Village of Wayzata ........... I

Village of West Minneapolis ....4

Total ...................... $\overline{60}$

\section{CITY DISTRICTS}

$\begin{array}{lllllllllllllllllllll}\text { Ward } & \text { I } & 2 & 3 & 4 & 5 & 6 & 7 & 8 & 9 & \text { I0 } & \text { II } & \text { I2 } & 13 & \text { I4 } & \text { I5 } & \text { I6 } & 17 & \text { I8 } & \text { I9 } & \text { Total }\end{array}$

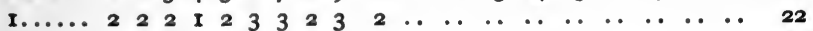

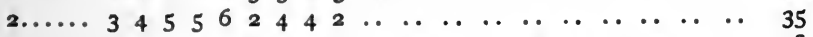

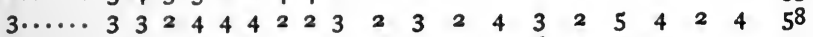

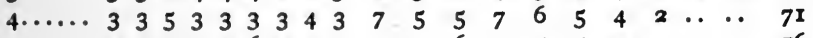

$\begin{array}{lllllllllllllllllllllll}5 & \cdots & \cdots & 4 & 3 & 3 & 3 & 4 & 6 & 4 & 3 & 7 & 7 & 7 & 6 & 7 & 5 & 5 & 2 & \ldots & \ldots & \ldots & 76\end{array}$

$6 \ldots \ldots .1328$

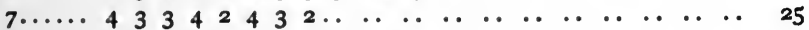

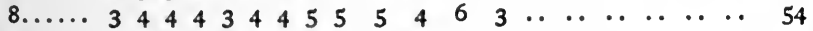

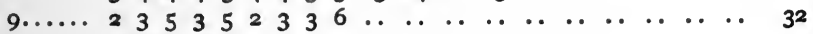

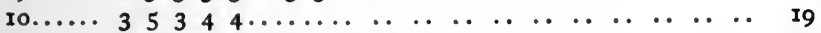

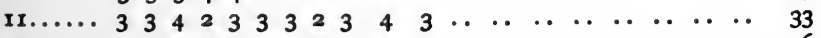

$12 \ldots \ldots .33=53 \ldots \ldots$

$13 \ldots \ldots .36 \ldots \ldots \ldots \ldots \ldots$

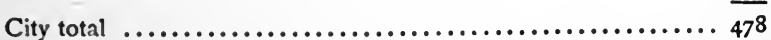

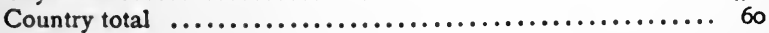

Grand total $\ldots \ldots \ldots \ldots \ldots \ldots \ldots \ldots \ldots \ldots \ldots \ldots \ldots \ldots \ldots \ldots, 53^{8}$ 
Organization the precinct committee calls the assemblage to order, of primary. and proceeds to form an organization. In case both of these officers are absent, any of the voters may act as the temporary chairman. From the members present a chairman, a clerk of election, and two judges of election are chosen by a viva voce vote.

The organization now completed, the chairman administers the oath of office to the newly elected officers. officers and the work of casting the ballots for delegates to the convention proceeds. The officers of the primary have particular duties to perform; the chairman administers the oaths and presides, the clerk makes minutes of the meeting and administers the oath to the presiding officer. The judges of election receive the ballots of the voters qualified to vote, and make a record of the name and address of every voter before he casts his ballot. After the hour of the pri-

The primary election for the selection of delegates to attend the Convention aforesaid shall be held in each election precinct in Hennepin County on Tuesday, the 24th day of May, 1898, at 7.30 o'clock P.M., and the polls shall be kept open for at least one hour, provided, however, that the polls shall not be closed until all qualified voters present at 8.30 o'clock and desiring to vote shall have an opportunity so to do, and shall be held at the November, 1896 , polling place in each precinct, except as the same may be changed in the further notices of said primary election, which will be posted in three public places in each precinct at least six days prior to the date when said primary election will occur. All voters, without regard to past political affiliations, who believe in the principles of the Republican party and who desire its success in the present campaign, are invited to participate in the selection of delegates to said Convention.

By order of the Republican Congressional Committee for the Fifth Congressional District.

S. B. LOVEJOY.

Chairman.

T. S. MAYER.

Secretary. 
mary has passed the judges count the ballots, and declare elected those who received a plurality of the votes cast. It then becomes the duty of the chairman and the clerk to furnish the delegates-elect with proper certificates of election.

The primary law is explicit and strenuous in regard Time. to the time of meeting, which is limited to the hours 2-9 P.M. If more than one primary is to be held in a city, town, or county, they must be held at the same hour and on the same day.

Under this law the parties that poll at least five per cent of the total vote cast inside a county, city, or district may elect delegates to their various local conventions. A State convention may be held by a party Conventions. that has polled a vote equivalent to one per cent of the total vote of the State. The State central committees of the various parties determine the number of delegates to the State convention that shall be allotted to the different counties. A regular rule has been established, largely by usage, basing the representation in the State convention upon the vote cast by the counties for the last preceding party candidate for governor. ${ }^{1}$ The delegates selected by the various primaries in a county meet at the call of the party chairman, choose their candidates for the county offices, and name delegates to the State convention. ${ }^{2}$

\section{Minneapolis Journal, December 2, 1899, first page.}

2 Primary Election Law, General Laws, 1899, ch. 349. This act applies to Hennepin County alone. In I 899 the legislature passed the above law applying to counties of two hundred thousand inhabitants and over. Under its provisions any person may become a candidate for an office in the county, if his petition is signed by ten per cent of the qualified voters necessary to his election. The primary election is held sometime before the regular election, and the members of the 
The delegates so selected from the various counties form the State convention. On a certain date set by the central committee the delegates assemble in one of the larger cities and proceed to the selection of candidates for the State offices, and delegates to the national party convention. When the different parties have made known their choice of candidates, the secretary of state arranges the names on the Australian ballot in time for the general election.

The second method of choosing candidates for political offices is by petition. The law provides every means to give to protestors and the minority some representation in the selection of candidates. Persons may be nominated for State offices when supported by a petition containing names to the number Nomination of one per cent of the total party vote at the last elecby petition. tion, for congressional or judicial positions when supported by a petition of five per cent of such voters. In the case of the city, county, and legislative officers the candidates' names must be accompanied by a petition of ten per cent of the party voters. But in no case shall over two thousand names be required for the State offices or more than five hundred for the others. ${ }^{1}$

The local government is put to a considerable expense in printing the ballots and preparing the blanks and notices of an election. The State law provides that a candidate for a State office or his friends

party then choose their candidates from the persons nominated by petition. On the tenth day before the regular election, the county clerk arranges the names of the candidates so selected on the election tickets.

1 General Lawe, 1895, ch. 135. 
must deposit $\$ 50$ with the secretary of state; the seeker for congressional honors must pay $\$ 20$ to the auditor of each of the counties composing his district; the county officers pay \$10 to have their names on the ballot of their party; and the candidates for city places deposit $\$ 5$ with the clerk of the municipality. In towns of less than three thousand this last amount is reduced to $\$ 3$. When the secretary of state, the county auditors, and the city clerks have received these sums and deposited them with the different treasurers, the names of the candidates may appear on the ballots.

\section{The Corrupt Practices Act}

The legislature in 1895 passed an act, as has been done in many other States, defining bribery in elections and limiting the expenditures of candidates for office. ${ }^{1}$ The penalties for the violation of the act are severe. This piece of legislation deals with bribery, stuffing the ballot box, and kindred offences, election expenses, contributions to party funds, disContents of bursements of money by party committees, and the method of procedure against actual or suspected violators of the law.

Bribery, as defined in the law, includes three separate acts: (I) the receiving of bribes, (2) the giving of bribes, and (3) the contributing of money with the Bribery and knowledge that it is to be used for corruption. Upon conviction the violators of the act may be subjected to imprisonment in the penitentiary for five years or to a fine of $\$ 500$. The framers of the law recognized

Fees of candidates. the act. corruption. 
that other means are open for corrupting voters, for they included in the law a clause against the use of force or coercion. The punishment in such cases is fixed at three months in the county jail. Gifts and banquets are tabooed under a penalty of a fine of $\$ 25$, while stuffing the ballot box is punishable by a five years' imprisonment in the penitentiary.

The act, however, permits the candidate to expend some money in a legitimate way. $\mathrm{He}$ is

Items of allowed to pay travelling expenses, rent of halls, expense. and the expenses incurred for speakers, challenges, clerks, the copying of poll lists and the canvassing of voters. The law further declares that all candidates for any public office within the commonwealth must report in writing, verified by affidavit, the amount of money spent for these different objects. This statement must be filed in the office of the county auditor within thirty days after the election. Any person failing to comply with this part of the law is liable to a fine not exceeding $\$$ IOoO.

The question as to what constitutes reasonable expenses is not left unanswered. The act states that no candidate shall pay out or expend in any manner connected with an election more than $\$ 250$ for five Reasonable thousand voters or less; $\$ 2$ more may be added for expenses. each hundred votes up to twenty-five thousand; for each hundred votes over twenty-five thousand and up to fifty thousand $\$$ I may be expended; and for each hundred voters over fifty thousand, fifty cents.

The party campaign committees usually come into the control of considerable sums of money during Campaign election periods. The legislature did not overlook this fact, and provided that the money of such com- 
mittees be distributed through a treasurer, who must file in the office of the county auditor within thirty days after the election an account of receipts and expenditures. If the committee neglects to do this a fine of one hundred dollars or an imprisonment of three months may be imposed on its members.

The reports, affidavits, and accounts filed by candidates in the offices of the county auditors are open to public inspection for four years. After that time the auditors or their successors shall destroy the accumulated reports.

In order the better to secure the enforcement of the act the courts are open, within limits, to those who wish to bring charges against officers who violate the law. Charges may be preferred against the successful candidate by the person having the next Action before the court. highest vote. The hearing before the court is secured by applying to the attorney general of the State to begin proceedings. In order to insure good faith this application must be accompanied by a bond of \$1000. The charges also must be set forth in specific and definite language. Within ten days after the receipt of the application and bond the legal officer of the State must either begin the action in person or instruct the county attorney of the county in which the officer resides to begin proceedings. If the attorney general refuses to comply with his request, the applicant may bring the action at his own expense.

Since the enactment of this law, the reports and accounts of committees and candidates have been filed with great regularity. Occasional complaints

Results of have been made concerning the expenditure of money, the law. 
but no important suits have been brought. The law, nevertheless, serves a very useful function in that it acts as a check upon election expenses and the conduct of candidates.

\section{Machinery of Elections}

Time of elections.

Election details.

Registration.

The general elections in the State are held in every even-numbered year, on the first Tuesday after the first Monday in November. At this time in every second, fourth, or sixth year, presidential electors, members of the legislature, representatives in Congress, State, county, and sometimes city officers, and the judges of the supreme and district courts are selected.

The machinery of elections is elaborate and intricate, although from the point of view of the voters the workings are comparatively simple; but back of the scenes of election day are the preparation of blanks, notices, and ballots, the appointment of election officers, registration, posting of the lists of voters, the counting of the ballots, the official canvass, and the final deposit of results with the various city, county, and State officers. In other sections of this chapter we have described the nomination of candidates; in this we shall have to do with the points just mentioned.

The voter first comes in contact with the election machinery through what is called "registration." By this is meant the listing of the names and addresses of all of those who are qualified electors. The intention of this part of the law is to prevent illegal voting and to give an opportunity to challenge voters. In all towns and cities having more than twelve hundred 
inhabitants, registration of voters is required by law. Such cities are divided into three groups: (1) those of less than twelve thousand people, (2) those having between twelve thousand and forty thousand, and (3) those of over forty thousand population. In the first group no regular questions are asked of the voter, although he takes an oath which binds him to answer such questions as may be put to him. In the second group, questions must be answered as to name, age, place of residence, nativity, color, length of residence in the United States, in the State, and district, as to Questions asked. ability to read English, and as to last place of registration. Foreign-born voters must also state whether they have received their first or second papers, and where such papers were taken out. To the questions asked in the second group are added, in the third group of cities, inquiries as to whether the voter is a householder, boarder, lodger, or employee. ${ }^{1}$ The boards that conduct the registration are required to meet in all the cities at least three times, and in the cities of over forty thousand inhabitants a fourth meeting is held on the Saturday previous to the election. On the days of registration the polls are open from six A.M. to nine P.M. After each day of registration the books are turned over to the city clerk or recorder for safe keeping. The law requires that at least ten days before election the list of voters must be posted in a conspicuous place near the polls.

One thing remains to be done before the election takes place, and that is the preparation of the ballots. Since 1891 the entire State is under the Australian

Preparation of ballots.

1 General Statutes, $1894, \S \S 60-72$. 
ballot system. ${ }^{1}$ The ballots containing the names of the candidates for State offices are white, the municipal ballots are red, and the county and miscellaneous offices are placed on a blue ballot. The first is prepared by the secretary of state, the city clerk arranges the second, and the county auditor the third. When the officer under whose authority the ballot is issued orders the facsimile of his signature to be printed under the words "official ballot," this action on his part designates it as such. Two weeks before the election the ballots must be ready for distribution, and at that time printed in the newspapers of the cities and counties. Sample ballots are kept in the offices of the city clerk, county auditor, and secretary of state for public inspection. On the day preceding the election the ballots are delivered to the judges of election by special messengers. Every precaution is taken to prevent fraud.

Selection of election officers.

Judges and clerks, how selected.

\section{The Conduct of Elections}

All preparations have now been made with the exception of the choosing of judges, clerks, and constables. These officers are selected some time before registration begins, but it is at this point in our description of election proceedings that we can best describe the method of choosing them.

In towns and townships where there is but one election district, the supervisors or town council may act as judges of election. The number of judges is three, but not more than two may be of the same political

1 For the Australian ballot system, see Wigmore, The Australian Ballot System. 
party. The judges in turn select one of the clerks of election, the town clerk serving as the second one. This plan is somewhat changed in towns and cities of two or more election districts. With respect to these the law provides that thirty days before the election the local committees of parties may furnish to the council a list of qualified electors who are willing to serve as judges. In cities of more than twelve thousand inhabitants a ballot judge is added to the number, making four judges. Except in the cities of less than twelve thousand inhabitants, ${ }^{1}$ the judges of each voting precinct choose four clerks. The fourth judge and two of the clerks render no service in the registration of voters, but appear on the election day. The election constables, like the clerks, are chosen by the judges.

The duties of the judges are comparatively simple. Duties. One of them has charge of the ballots. He delivers to the voter the several ballots and receives from him the ballots which he has marked in the booth. The ballot judge then places each ballot in its proper box. The other two, or in case of cities of over twelve thousand inhabitants, three, have control of the registers compiled from the names of electors registered previous to the election, and mark the name of each voter when he delivers his ballot to the ballot judge, who deposits it in the proper box. The clerks keep poll lists in which the name, residence, and the color of the ballot box in which the ballots are cast are noted. These lists are supposed to correspond with those kept by the judges.

The ballots are in the form of the Australian ballot, 
and must be properly marked by the voter. Any technical error does not cause the rejection of the vote unless it is impossible to determine the intention of the voter. The elector in case he cannot write may receive aid from some person appointed by the ballot judge.

\section{I. Canvassing Boards}

As soon as the polls are closed the ballot boxes are opened in the presence of judges, clerks, and party challengers, and the counting begins. The judges of election first prepare, at the end of each poll list, a summary of the number of persons present and voting, the number of women, and the number of white, red, and blue ballots recorded as cast. When

Opening of the boxes. the statements have been prepared and signed, the ballot boxes are opened, examined, and the ballots taken out and arranged. Beginning with the boxes containing the votes for State officers, the ballots are counted to see if the number agrees with the poll list. If the numbers are in accord the judges proceed to ascertain the number of votes cast for each candidate, the clerks keeping tally on sheets provided for the purpose.

After the judges of election have finished the count, and signed a statement of the results, the ballots are placed on a string and returned to the box from which they were taken. These boxes are sealed Canvassing with papers on which are written the names of the judges. The boxes are deposited with the town or city clerk, and are not opened until the next election unless necessary to verify the results. The poll lists 
and one of the registers is deposited with the clerk, and the others are sent to the office of the county auditor. The law requires the judges to deposit the returns, ballot boxes, and registers with the city clerk as soon as possible, the limit of time being twenty-four hours after the election. ${ }^{1}$

The returns for county candidates are sent to the county auditor, who, within the next ten days, calls a canvassing board consisting of himself, the chairman County boards. of the board of county commissioners, and two justices of the peace of opposite political parties residing in the county. The business of this board is carefully to examine and sum up the returns, and to make a sworn statement concerning (I) the whole number of votes cast for each candidate on the State ticket, (2) the whole number of votes cast for county officers and members of the legislature, and (3) to do the same in reference to the votes cast for presidential electors, representatives in Congress, and constitutional amendments. When the board has declared the candidates for county offices receiving the highest number of ballots elected, the county auditor makes out a certificate of election for each successful candidate. As a final act the board sends certified statements of the results to the secretary of state, who in time presents them to the State canvassing board.

Eighteen of the senatorial districts in the State are composed of two or more counties, which necessitates a third canvassing board known as the senatorial district canvassing board. ${ }^{2}$ The auditor of the senior

Senatorial district board.

1 Minnesota General Statutes, 1894, §§ 156-192.

2 General Statules, 1894, \$\$ 175-1 77 . 
county calls together on the twentieth day after the election the chairman of the county commissioners of his county and two justices of the peace, with such auditors of the counties composing the district as care to attend. The board then opens and inspects the returns from the several counties, and declares those receiving the highest vote elected. The auditor then makes out certificates of election to the members of the legislature from that district.

From all parts of the State the county auditors send the returns for the State officers to the secretary of state. This officer calls to his aid two or more

The State board. judges of the supreme court, and two disinterested judges of the district courts of the State. On the third Tuesday in December, after the election, these officials meet in the office of the secretary of state and go over the returns, and make a sworn statement concerning the votes received by candidates for State offices, members of Congress, and presidential electors. The persons receiving the largest number of votes for these different positions are given certifcates of election signed by the governor and the secretary of state.

This act on the part of the State canvassing board completes the machinery of election. On the first day of January, with a few exceptions, the officerselect take their positions and begin their service for the State. 


\section{CHAPTER VII}

\section{THE ADMINISTRATION OF JUSTICE}

\section{REFERENCES}

Wilson, The State (revised ed.), §§ 1147-1172; Bryce, The American Commonwealth, I. ch. xlii.; General Statutes of Minnesota, 1894; Dunnell, Minnesota Trial Book, ch. ii.; Legislative Manual, 1899; Booth, Township Manual, ch. iv., section on Judiciary.

\section{The Judicial Power}

Two of the most important of the functions of the State are the maintenance of order and the administration of justice. The first is largely an executive duty, but in performing it the governor and other of the courts. executive officers must frequently rely upon the assistance of judicial tribunals. The second is purely a judicial function, and is vested in the courts. No other function that any government undertakes surpasses it in importance. Under it the State punishes crimes which, because of the fact that they menace the life and property of all the people of the community, are regarded as offences against the State rather than as offences against the person injured. Through the courts also private individuals seek to protect their rights and to secure the redress of wrongs committed against them. Certain of the courts assume the protection of the persons and property of the 
insane, minors, and others who are thought to be incapable of defending themselves.

In these courts two kinds of actions may be

Civil and criminal actions.

Judicial system. brought, called civil actions and criminal actions. ${ }^{1}$ The first or civil action may be instituted by the State in its capacity as an owner or contracting party, or by a subject or citizen, for the purpose of maintaining a right, collecting a debt, or for damages for an injury or wrong to person. A criminal action is brought when the State attempts to prove the guilt of a person for an act or omission forbidden by law. Such acts or omissions are called crimes, and are defined by statute.

The judicial system of Minnesota is largely a creation of the legislature. The constitution says, "The judicial power of the State shall be vested in a supreme court, district courts, courts of probate, justices of the peace, and such other courts, inferior to the supreme court, as the legislature may from time to time establish by a two-thirds vote." 2 These courts may be grouped for convenience in treatment under three heads, local courts, district courts, and the supreme court.

\section{The Local and District Courts}

There are three local courts: the justice of the peace courts, town or city courts, and the probate courts. The law provides that each township may elect two justices of the peace and two constables

1 Being what is called a code State the distinction between "actions at law" and "suits in equity" is abolished, such cases coming under civil actions.

2 Constitution of Minnesota, Art. VI., Sec. $\mathbf{x}$. 
every two years. In each city justices of the peace are elected for the same period. ${ }^{1}$ This officer is, therefore, primarily a local one. The justice's court machinery consists of a constable and a jury. When Justice's court.

it is necessary to secure a jury the justice directs the constable, or possibly the sheriff, to make a list of twenty-four persons, residing in the county and qualified to vote, to serve as jurors. From this list each party to the cause may strike six names. In case of agreement between the defendant and plaintiff, the jury may be reduced to six persons.

The jurisdiction of a justice of the peace is original ; that is, all cases which a justice hears begin in his court. None can be appealed to it, for it is the lowest court in the system. The justice has power within Jurisdiction. the limits of the county to order the arrest of persons breaking the peace, or who are charged with any criminal offence. He may commit to jail, require security to keep the peace, or bail for appearance at a higher court, but he does not have any final jurisdiction when the punishment for the offence exceeds three months' imprisonment or a fine of $\$ 100$. In civil cases the jurisdiction of this court extends to actions on contracts for the recovery of money, to suits for damages for injury to person or property, and to actions on bonds, provided the sum involved in such cases does not exceed \$100. In cases relating to a title to real estate, false imprisonment, libel, slander, seduction, breach of promise to marry, divorce, or actions against an executor or administrator, the justice has no jurisdiction. ${ }^{2}$

1 Abolished in Minneapolis, 1899.

2 General Statutes, $1894, \S \$ 4959,4960$. 
City justices. The justices of the peace elected within the boundaries of a municipal corporation are called city justices. They possess a somewhat larger power and jurisdiction than the county justice. In addition to the jurisdiction described above the city justice has the right to hear and try all violations of the charter provisions, ordinances or by-laws passed by councils, and cases of larceny where the amount stolen does not exceed $\$ 25$. In fact all offences not indictable, such as assaults, batteries, affrays, drunkenness, disorder, and breaches of the peace, so long as the punishment does not exceed $\$$ IOO fine or three months' imprisonment, may come before a justice of the peace for trial. ${ }^{1}$

But there are, despite the enlarged powers of the Municipal courts.

Jurisdiction of the municipal court. city justice, a great many cases, civil and criminal, that are not within his jurisdiction. This is particularly true in the larger cities. In order to relieve the district court from such matters, another local court has been created called the municipal court. Any incorporated city may establish such a court. The municipal court has a judge, a clerk, and a seal. It has power to hear, try, and determine civil actions at law where the amount in controversy does not exceed $\$ 500$. It also has jurisdiction to hear criminal complaints and conduct examinations and trials in criminal cases arising within such cities where the jurisdiction is co-extensive with the county and equivalent to that of a justice of the peace. The powers of the court do not extend to actions involving the title to real estate, divorces, libel, breach of promise, civil actions against the city, or any 
action involving over $\$ 500$ against an administrator or executor. ${ }^{1}$

The judge of this court is elected for a period of four years and receives a salary varying with the Officers of the court. size of the city. ${ }^{2}$ In towns of less than five thousand inhabitants the chief magistrate of the city acts in the capacity of judge. The judge is to hear and dispose of cases brought before him by the police officers or marshals of the city. The clerk of the court keeps the records, swears the witnesses and jurors, and administers oaths.

The third local court is the probate court, established in order to relieve the district court of the business of administering estates, wills, guardianships over children, and the examination of insane persons. In the case of a will, the probate court (I) orders the payment of the debts of the deceased, and (2) divides the remaining property among those who are entitled to it. If a will, in legal form, has been left, the division of the property follows the desire of the former possessor as expressed in the will; but if no will is left, the judge proceeds in accordance with the law. The steps in the probating of a will are as follows: petition for probate; notice, by publication in the newspapers, to those interested; in probating proof of the validity of the will; admission to proa will. bate; appointment of an administrator, or, in case the executor is named in the will, confirmation of the nomination; settlement and order for payment of debts; division of the property. When there is no will, the proceedings are much the same. Some one interested in the estate petitions for the appointment

1 General Laws, 1895, ch. 229.

2 Ibid., 1899, ch. 27 I. 
of an administrator; after notice to all concerned the court makes such an appointment; the proceedings are then the same as in the case of a will; the division of the property, however, is in accordance with the law of the descent of property. The other duties of the probate court are just as important. The commitment of insane persons to an asylum and the appointment of guardians for minors are difficult tasks. This court is, indeed, one of mercy in its dealings with orphans, widows, and the weak.

The district courts have two kinds of jurisdiction, original and appellate. They have original jurisdiction in all civil actions within their respective districts when the sum in controversy exceeds $\$$ roo, in those cases where a justice of the peace has no jurisdiction, and in the case of crimes and misdemeanors, where the fines and punishment exceed $\$ 100$ and three months' imprisonment. The appellate jurisdiction of the courts extends to civil and criminal cases appealed from the courts of probate and justices of the peace. Appeals may also be made to these courts from the orders of the railroad and warehouse commission, board of health, the factory inspectors, the decisions of county boards on allowances, city condemnation of lands, and county commissioners. $^{1}$

In term time the courts, and in vacation the judges

Writs and of the district court, may issue writs of injunction, mandamus, ne exeat, certiorari, habeas corpus, and such other writs and processes as may be neces-

1 General Statutes, 1894, index title, "Appellate Jurisdiction." 
sary. 1 These writs can be served in any part of the State, but are returnable to the proper county.

\section{The Supreme Court}

The jurisdiction of this court is largely appellate; appeals are taken to the highest court from the district courts, where its decisions are reviewed by the supreme court. The decisions are rendered in writing, and stand as the law of the case and of the State quite as effectively as a legislative act. In fact a legislative act may be declared void by the supreme court if found to be in conflict with the constitution. It must be remembered that the highest court of the State does not hear jury trials, but passes only upon questions of law except in cases when "writs" have been issued by the court. The supreme court has power, in addition to the trial of appealed cases, to issue writs of error, certiorari, mandamus, prohibition, quo warranto, and other writs which are issued in furWrits. therance of justice and the administration of law.

The chapter on "Central Government" under the section "Judiciary" describes the number of courts, the tenure of office of the judges, and their relation to each other. The first part of this chapter has been devoted to the jurisdiction of the different judicial bodies, but we still know but little of the real work-

Procedure.

1 Mandamus - a command issued by a superior requiring a lower court, corporation, or official person to do some specific duty.

Ne exeat - a command to a sheriff or constable to hold a person at the order of the court.

Certiorari-a writ from a superior to an inferior court directing that 2 certified record of a certain case be sent up for review by the superior court. 
ings of the courts. Of this, however, we may learn by an examination of the procedure followed in the trial of civil and criminal cases.

\section{Civil Procedure}

Undoubtedly the best way to review the method of procedure is to begin with the introduction of a case in the district court. If we suppose that a man has been damaged by the loss of a horse on account of a neighbor's negligence, we have the basis of a civil The case. case. Having decided to carry the matter into the courts, he seeks a lawyer in the county seat and asks his advice. After the various points have been talked over the lawyer prepares what is called a "complaint." This document contains three points, first, the title of the cause, the court, county, and the names of the parties, - the plaintiff who brings the suit, and the defendant against whom it is brought; second, a plain and concise statement of the facts constituting the cause of action; and third, a demand for the relief to which the plaintiff believes himself entitled. ${ }^{1}$ The attorney files the complaint with the county clerk, and notifies the defendant that an action has been brought against him.

The second step in our case is the answer of the defendant to the complaint filed by the plaintiff, which is done within the twenty days allowed by the law after service. Sometimes the defendant's answer Answer. contains new matter, and if it does the plaintiff is granted the same time in which to file a reply. The

${ }^{1}$ For civil trial, see General Statutes, $1894, \S \S 5156-5386$. 
general term "pleadings" is used to describe the papers filed in the case. ${ }^{1}$

"Issues" arise upon the pleadings, when a fact or conclusion of law is maintained by one party and controverted or denied by the other. ${ }^{2}$ The trial of Issues. the issue constitutes the third step in the proceedings. The first of these issues arises upon a question of law in relation to the documents or pleadings of the defendant and plaintiff; the second upon the statement of facts made by the plaintiff, or defendant. When an issue is joined a trial is the result. A trial is the judicial examination of the issues or dispute between parties, and may be tried by the court or by a jury. Issues of law are tried by the court, issues of fact by the jury. Sometimes in the latter case trial by jury is waived, and the matter referred to a referee. In our case, however, the issue is one of fact; both parties insist upon a jury trial.

At any time after issue, but at least eight days before the term, either party may give notice of trial. The law provides that the party giving notice must furnish the clerk of the court with a "note of issue" containing the names of the parties, and their attorneys, and when the last pleading was served. When this has The trial. been done, the clerk enters the cause upon the court calendar or list of cases for trial according to the date of the issue. The court disposes of the various cases in this order: ( $\mathrm{I}$ ) issues of fact, to be tried by a jury ; (2) issues of law, to be tried by the court. Let us say that the day of the trial has come, the judge, attorneys, and parties to the case are present, but a jury must be secured before the trial can proceed. This is the 
Petit jury. next step. The petit or trial jury consists of twelve men impanelled and sworn in a district court to try and determine questions of issue, or fact, in any civil or criminal proceeding. The names of electors qualified to act as jurors are compiled by the board of county commissioners. ${ }^{1}$ These officers make up two lists of seventy-two names each, one for each jury. When the lists are completed they are turned over to the clerk of the district court, and from them the juries are selected in the presence of witnesses.

On the second day of the term of court the judge orders the clerk to draw from the jury box not less than twenty-four names and not more than thirty-six for a petit jury. After this has been done the clerk Selection of notifies the jurors of their selection, and, unless legally jurors. excused, they are compelled to serve. The court also orders the clerk to draw as many extra names as will be necessary to make juries sufficient to serve two weeks each during the term. The petit jury now being provided for, we may proceed with the trial.

The names selected by the clerk are put in the jury box, and on the day of the trial the clerk draws names until the panel, or jury of twelve men, is completed. There is still the possibility that both sides may challenge the jury or object, as allowed by the law, to certain persons drawn as jurors. ${ }^{2}$ As soon as the jury is chosen, ( $I$ ) the plaintiff's attorney opens

1 There are a few exceptions to this statement. Hennepin County selects 135 names for grand jurors, and 250 for petit jurors; Ramsey County, 100 for grand and 200 for petit jurors; and St. Louis County, 400 for both juries. In these counties, including Washington, the selection of jurors is left to boards differently constituted. General Statutes, 1894, §§ $5611,5621,5628$.

2 For method of challenges, see Dunnell, Minnesota Trial Book, ch. ii. 
the trial by stating the issue and presenting the evidence; (2) the defendant through his attorney preProcedure of sents his defence substantiated by such evidence as he can produce; (3) both sides then offer rebutting evidence; (4) which is followed by the arguments of the plaintiff's and the defendant's attorneys; (5) the court charges the jury, explaining the powers of juries and the law applying to the case; (6) after due deliberation the jury returns its verdict in writing to the court, where it is filed.

The verdict of the jury may be unsatisfactory to one of the parties; in such case he can ask for a new trial, New trial. which the court may grant or deny. The new trial will be granted providing the aggrieved party can show reasons, such as irregularity, misconduct, verdict contrary to law or the evidence, new evidence, or error of law. If either party is not satisfied with the ruling in reference to the new trial, he may appeal to the supreme court. The party appealing the case is known as the "appellant," and the second Appeal. party as the "respondent." The appeal is made by the service of notice on the latter and on the clerk of the district court with whom the judgment or verdict has been filed. When this has been done the clerk transmits to the supreme court a copy of the judgment, evidence, and the papers upon which the verdict and judgment were made, which are then printed. ${ }^{1}$ The time for the filing of the papers on appeal is limited to six months after the entry of judgment. The clerk of the supreme court prepares the calendar, and before the opening of the term the attorneys must file with him their printed briefs. On the day

1 General Statutes, 1894, §§ 6132-6154. 
set for the hearing the attorneys argue the case before the judges of the supreme court. These judges have the power to reverse, affirm, or modify the judgment of the lower court, and may, if considered necessary, order a new trial in the district court. The decision of the supreme court is always presented in writing, and when once submitted cannot be changed by appeal to a higher tribunal, except in cases involving Decisions. questions in the jurisdiction of the Federal Government, which may be taken to the Supreme Court of the United States. The mandate of the supreme court, after the decision has been reached, is sent to the clerk of the district court from which the case was appealed, who notifies the party against whom the judgment has been rendered. If necessary he may issue an execution, which is served by the sheriff and stands against the property of the defendant until the judgment is paid; but if a new trial is ordered the whole case is heard a second time.

\section{Criminal Procedure}

Crime defined.

Criminal procedure differs considerably from the trial of a civil case. A crime is an offence against the law and dignity of the State, and is defined as an act or omission forbidden by law. It is punishable by death, imprisonment, or other penal discipline. ${ }^{1}$

When a person is charged with the commission of a crime and is arrested therefor, he must be informed at once of the cause of his arrest. The arrest may be made by a peace officer with or without a warrant, or by a private person. Let us begin

${ }^{1}$ For the penal code, see General Statutes, 1894, ch. 92. 
with the arrest by warrant, as this is the usual way. The complainant appears before a magistrate, and if upon examination it is shown that a crime has been Arrest. committed, the court issues a warrant (which is a paper directing the taking of the person) for the arrest of the accused person. When the officer to whom the warrant is addressed takes the prisoner into custody, the magistrate may admit the prisoner to bail, under which he agrees to appear for examination. If the offence is punishable with death or imprisonment in the State prison for seven years or over, the justice of the peace cannot admit him to bail. ${ }^{1}$

It is at the point of examination that several im- Examination. portant questions arise. As soon as possible the person arrested is examined by the magistrate, witnesses are questioned under oath, and if it appears to the magistrate that no offence has been committed he discharges the prisoner; but if it appears that an offence has been committed, and there is probable cause to believe the prisoner guilty, the prisoner is committed to jail to await trial. As has already been shown, the prisoner may be admitted to bail; in such case he agrees to appear before the superior court on the day appointed by the magistrate. Meantime the latter sends to the district court a certified copy of the examination and the endorsement "Admitted to bail."

Sometimes a magistrate delays the examination of a prisoner or makes an illegal commitment. When this is done the prisoner may demand a writ of Habeas "habeas corpus." There are few exceptions to this right. The demand may be made by the prisoner or 
some person in his behalf to the supreme court or district court. This petition for release must state the reasons for the demand. ${ }^{1}$ The writ, if issued, is addressed to the officer having the prisoner in charge, ordering him to bring the person arrested before the judge issuing the writ. Then follows an examination similar to the one described in the previous paragraph, and if innocent of the offence the prisoner is discharged; otherwise he is either committed for trial or admitted to bail. "When the latter appears for trial the court may order him to be committed to the custody of the sheriff, to abide the further order of the court."

The State constitution provides that "No person shall be held to answer for a criminal offence unless

Presentment and indictment.

on the presentment or indictment of a grand jury, except in cases of impeachment, or in cases cognizable by a justice of the peace, or those arising in the army and navy." 2 Further progress in the prosecution of the case is delayed until a grand jury makes a presentment or indictment against the accused. So we are confronted by the query, What is a grand jury?

"A grand jury is a body of men, not less than sixteen nor more than twenty-three in number, reThe grand turned at stated periods from the citizens of the jury. county, before a court of competent jurisdiction, chosen by lot, and sworn to inquire of public offences committed or triable in the county." 3 The members of a grand jury are chosen from the list sent to the

1 General Statutes, 1894, §5998.

2 Constitution of Minnesota, Art. I., Sec. 7 .

8 General Statutes, 1894, § 71 70. 
clerk of the court by the county commissioners. Fifteen days before the opening of the term the clerk draws from a box, in the presence of the sheriff and a judge or justice of the peace, the names of twenty-three persons to serve on the grand jury. A prisoner held on a charge may challenge any individual juror for cause, which he must show. When the jury has been impanelled the court appoints one of the jurors foreman. After being sworn the jury retires to a room, elects a clerk, and begins the inquiry. It is declared by law that the grand jury Indictments and presentmust inquire: ( $\mathrm{I}$ ) into the condition of persons imprisoned and not indicted; (2) into the management of public prisons; (3) and the conduct of public officers in the county. This body of men deliberates in secret upon the offences committed within the county. If the jury is convinced that there is sufficient evidence to justify the trial of the accused person, it returns a presentment or indictment. A presentment is a formal accusation made by a grand jury from its own knowledge or from evidence which is before it. An indictment is an accusation drawn up by the public prosecutor and submitted to the grand jury. The evidence upon which the accusation is based is then examined, and if it appears insufficient to justify a trial, the indictment is endorsed "Not a true bill" or "Not found," and the prisoner is released. But if the evidence points to the probable guilt of the accused, the indictment is endorsed "A true bill," and the accused is held for trial. A majority of the jury must concur in presentments and indictments. It should be remembered that presentment or indictment by a grand 
The trial of the accused.

jury does not convict of crime. It merely says that sufficient evidence has been brought against the accused to justify further investigation by a regular judicial process before a court.

The clerk of the court prepares the criminal calendar which includes the names of the persons indicted, accompanied by the statement whether they are in custody or on bail. The trial now proceeds. The defendant may move to have the indictment set aside. The arguments for and against this motion are then heard; if the court decides the indictment may be set aside the prisoner is free, otherwise the trial goes on. As in the case of a civil action the defendant charged with a crime may enter a demurrer. ${ }^{1}$ This is the second step. The defendant must show cause for the granting of the demurrer. The "motion to set aside" and the "demurrer" having been refused, the prisoner may plead guilty or not guilty to the indictment. If he pleads not guilty, an issue of fact arises which must be tried before a petit jury chosen in the same way as in a civil action. At every step the defendant may call in witnesses to meet the evidence of the prosecution.

Sometimes a jury disagrees, in which case the court discharges the jury, and a re-trial is ordered; the whole matter is gone over a second time. When a The verdict. verdict is reached the clerk records it on the minutes of the court, and the judge, if it is a verdict of guilty, then pronounces sentence. The prisoner, however, may appeal the case to the supreme court, which has power to affirm, reverse, or modify the sentence, or

1 A demurrer is an objection to the indictment on the ground that the facts do not constitute a sufficient basis for a legal action. 
order a new trial. The proceedings in the higher court in criminal actions are similar to those in civil cases already described in the previous section, with the exception that the State has no right to appeal if the verdict is in favor of the accused person.

It is possible for the parties to a criminal action to secure a "change of venue," that is, a transfer of the case to another district court or county for trial. This is permitted when there is proof that a fair and impartial trial cannot be had in the county where the case is pending. The court does not order a change of venue unless thoroughly persuaded that an impartial trial is impossible; when the judge is so convinced the case may be transferred to some other county within the State.

It will be observed in tracing the various steps in criminal procedure that the prisoner has many chances to prove his innocence. In fact, the State is bound to prove his guilt. At no time in the progress of the trial does the court take it for granted that the Change of venue. accused is guilty, but at all times, until a verdict of guilty is rendered, the law presumes the accused to be innocent. Beginning with his arrest the prisoner has an opportunity at his examination to prove his innocence. If he fails in this, or the examination is delayed, he may apply for a writ of "habeas corpus." Then comes the indictment by the grand jury, which the defendant, through his attorneys, may move to set aside. An argument and decision must be made on this point before the case can go farther. Again, the accused may demur to the indictment; then, if the indictment has held good, he has an opportunity to plead guilty or not guilty. From this point in the

The safeguards of justice. 
trial proceedings, the defendant is allowed to challenge the jury, and to present arguments and evidence. Even after the verdict is announced, there is still the possibility of a new trial, and the certainty of an appeal to the supreme court.

Both in civil and criminal procedure every safeguard is placed about the rights of the parties. Par-

The greatness of the law. ticularly is this true in the trial of persons accused of crime. We often hear disparaging remarks concerning the law, but a knowledge of it impresses one with its greatness, importance, fairness, and wisdom. The Anglo-Saxon civil and criminal procedure is the result of centuries of development and years of warfare and struggle. It is the bulwark of our liberties, and is deserving of our highest respect, even though justice at times may seem to miscarry or result in the acquittal of some person whom the community believes to be guilty. 


\section{CHAPTER VIII \\ REVENUE AND EXPENDITURE}

\section{RefERENCES}

Bryce, The American Commonwealth, I. ch. xlviii.; Adams, The Science of Finance; Plehn, Introduction to Finance; Daniels, Public Finance; General Statutes of Minnesota, 1894 ; General Laws, 1895, 1897, 1899 (see index); Legislative Manual, 1899; Report of the Auditor of State, 1899 .

\section{Receipts and Expenses}

The expense of the Minnesota State government has averaged in the last few years $\$ 5,250,000$ per annum, while the local and county governments have cost the people nearly $\$ 15,000,000$. The disburse- Expenses. ments of the central government for the payment of expenses consisted of twenty-five items, among which are the expenses of legislative, executive, and judicial departments, State institutions, public schools, bounties, grain inspection, national guard and Spanish war, drainage commission, and interest on the State debt. ${ }^{1}$ The items of local expense vary with the community, but include salaries, the expenses of roads, lighting, public buildings, policing, fire protection, and many other items.

The revenue of the State comes from the regular State tax, railroad, insurance, telegraph and telephone

1 Legislative Manual, 1899, pp. 558, 568. 
Sources of taxes, incorporation fees, interest on deposits, earnrevenue. ings of State institutions, sale and lease of public lands, royalties on mining ore, and departmental earnings. ${ }^{1}$ The resources of the local governments are almost entirely limited to the taxation of real and personal property, fines, and licenses, and in some cases receipts from water rates where the community owns the water plant. The legislature has thus clearly stated the sources of taxation:-

"All real and personal property in this State, all personal property of persons residing therein, the property of corporations now existing or hereafter created, and the property of all banks existing or hereafter created, and of all bankers, except such as is hereinafter expressly excepted, is subject to taxation, and such property, or the value thereof, shall be entered in the lists of taxable property for that purpose, in the manner prescribed by this act; provided, that railroads, insurance, and telegraph companies shall be taxed in such manner as now is or may be hereafter fixed by law." 2

\section{The Kinds of Taxes}

The revenues of the State are raised, so far as Taxes. taxes are concerned, by the levy upon personal and real property, and the gross earnings tax on the incomes of railroads, express, insurance, sleeping-car, and telegraph companies. The local governments

1 The instructor will do well to read carefully some of the general works on finance, so that a clear statement of the methods of levying and collecting taxes may be made to the students.

2 General Statutes, 1894, § 1508. 
rely upon the taxation of the personal and real property within their jurisdiction for their support. The first kind of property consists of personal belongings, which include all kinds of money, goods, chattels, effects, evidences of rights in action, and all written instruments bringing to the owner an increase of income or evidencing an ownership of rights or interests in other property. ${ }^{1}$ The second is land and houses, and is defined by the law as "every estate, interest, and right in land, tenements, and hereditaments." 2 The "gross earnings tax" was established in 1873 and afterward modified in $1897 .^{3}$ Under this law the various companies enumerated above are compelled to pay into the State treasury three per cent of their gross incomes, but the payment of this tax relieves the companies from all other taxes. ${ }^{4}$

In some cases another tax is sometimes laid. It is lawful for the common council of a city or town to levy a local tax, known as a poll tax. The amount of the tax is limited to $\$ 2$ in any one year, and is laid upon voters only. ${ }^{5}$

\section{The Assessment of Property}

Some basis is necessary for taxation, and this, in the case of personal and real property, is the wealth held in such forms. To ascertain the amount of

1 General Statutes, $1894, \S 6842$.

2 Ibid.

8 General Lazus, 1873, ch. 111, § 1; 1897, chs. 159, 160, 309, 314. See also General Statutes, $1894, \$ \S 1667,1668$.

4 An inheritance tax is authorized by the constitution, but the law passed a few years ago was declared unconstitutional by the supreme court, February 15, 1900.

- General Statutes, 1894, § 1105. 
Assessors. property owned by citizens is the first step; for this purpose officers called assessors are elected in townships, and appointed in villages, towns, and cities by the common councils. In the townships, the service is for one year and the compensation $\$ 2$ per day. In the towns, villages, and cities, the service is for two years and the compensation fixed by the councils. During May and June the assessors, having received the books and blanks from the county auditors, pass upon the property in their districts. In odd-numbered years, both personal and real property are assessed; in even years only the personal property is listed.

Exempted property.

Review of Assessments.

The law exempts certain forms of property from taxation. All public property, such as public buildings, churches, universities, charitable institutions, fire engines, market houses, town halls, and public libraries, are free of taxes. The personal property of each individual liable to assessment is exempt to an amount not exceeding \$IOO. The assessor makes a note of these deductions, and the auditor, in filling out the tax lists, deducts the exemptions from the total assessments and levies the tax upon the remainder. After the examination of the property lists by the boards of review the assessors' books are returned to the auditor.

Complaint of some kind is sure to arise when property is assessed; the property holders, in the case of a grievance, may appeal to the boards of review. There are three classes of such boards, town or city boards, county boards, and State boards of equalization. On the fourth Monday in June, after having given ten days' notice, the town board meets at the 
office of the town clerk or recorder. This board consists of the supervisors, assessor, recorder, and president of each incorporated village, and the assessor, recorder, and mayor of each city. ${ }^{1}$ At that time a The town board. review is made of the property list and assessments, and if in the opinion of the board any assessment is wrong or does not appear at all on the books of the assessor, the board makes the assessment or changes the valuation as it sees fit. During its sessions persons who consider themselves aggrieved may have their assessments reviewed.

When the work of the town board is finished, the assessor makes a tabular statement of the property assessed, together with the changes noted by the board of review, and turns the lists over to the county auditor, accompanied by an affidavit certifying to their correctness. All of this is accomplished by the first Monday of July. The auditor then examines the work of the assessor and the board of review, and if any errors or omissions are found notifies the assessor to make the proper assessment; if the latter refuses to do this, the auditor makes the corrections.

The unequal assessment of property in the different parts of the State, due to the assessors and different economic conditions, has brought into existence two other boards known as the county and State boards of equalization. The first meets on the third

Boards of equalization. Monday of July, and endeavors to equalize the property valuations of the various towns and cities inside

1 Some city charters provide for boards of equalization; in such case the membership differs from those described above. General Statutes, 1894, §1547. 
the county; its membership consists of the county commissioners and the auditor. ${ }^{1}$ When the work of the board is finished the auditor sends a record of the proceedings to the auditor of the State. The second board, consisting of the governor, the State auditor, attorney-general, and one qualified elector from each judicial district, attempts to do the same for the counties of the State that the county board does for the towns, villages, and cities in the county. ${ }^{2}$ In Duties of the reference to their duties the law says, "The board State board. shall meet annually, on the first Tuesday in September, at the office of the auditor of State, and, each member having taken the oath prescribed by law, they shall examine and compare the returns of the assessments of the property in the several counties of the State, and proceed to equalize the same, so that all the taxable property in the State shall be assessed at its true and full value." 3 The secretary of the board, in other words, the auditor, sends to the county auditors an abstract of the State board's proceedings, specifying the per centum added to or deducted from the valuation of the property in the towns, villages, cities, and counties of the State.

A very important step is still to be taken. It is now necessary to determine the rate of taxation. This brings us to the question of tax levy.

52. The Levying and Collection of Taxes

The State tax is levied by the legislature, the county tax by the county commissioners, the vil-

1 General Statutes, 1894, § 1552. 2 See Appendix L.

${ }^{3}$ General Statutes, $1894, \S 1555$. 
lage or city tax by the common council, and the town tax by the town meeting. The taxes voted by towns, cities, and villages must be certified to the county auditors before the tenth day of October in each year. The total of these estimates of funds necessary for the different governmental organizations of Estimate of taxes. the State is the amount to be raised by taxation. Knowing the value of assessed property and the various amounts desired by the State, county, city, and township, the auditor is able to ascertain the total tax rate; but the officers of the local government are prevented by legislative act from levying too high taxes upon the property of the people.

The general act of 1895 , providing for the government of cities, institutes a somewhat more elaborate machinery for the levy of taxes and the determination of the rate. ${ }^{1}$ Under this law two committees have to do with the tax levy. The conference committee, consisting of the president of the council, the head of each board and of each department of the city government, meets in September of each year and forms an estimate of the necessities of each department, and presents to the board of tax levy a report of the estimated expenses for the ensuing year. The second committee, called the tax levy board, is made up of the mayor, the president of the council, and the comptroller. This board fixes a maximum rate of taxation; the reports of both committees are sent to the council, but this body (however it may alter the estimates), cannot change the maximum rate established by the board. When the rates are determined by the local governments,

City boards of conference and tax levy.

1 General Laws, 1895, ch. 8, \$§ 104, 105. 
the county auditors make out the lists, and by January I deliver them to the county treasurers for collection.

The statutes designate the county treasurer as The collec- the receiver and collector of all taxes. ${ }^{1}$ On receivtion of taxes. ing the tax lists from the county auditor the treasurer notifies the community of the rate and the amount due, either through the columns of a newspaper or by special notices mailed to each taxpayer in the county. All taxes are due on January I. The county treasurers do not collect the gross earnings tax; their duty is limited to the real and personal property taxes. The personalty tax is payable, without penalty, until the first day of March, when a

Personal property taxes.

Real property taxes. penalty of ten per cent is added. On the first day of April the treasurer is authorized to make a list of the delinquent personal taxes, and send the same, certified, to the clerk of the district court. This officer then issues warrants to the sheriff of the county giving him power to seize the property, and if the taxes are not paid within ten days to sell it at auction. If the owner redeems the property before it is sold he must pay the taxes, penalty, and costs before it is returned to him.

The real estate taxes may be paid in two equal instalments. The payment of the first half may be delayed until May 3I, but on June I a penalty of ten per cent of the whole tax, if this first half is not paid at that time, is added. The second half is due October 3I. If it is not paid by November I, an additional ten per cent increases the taxpayer's burden. The whole tax becomes delinquent on January I 
following, when a third penalty is added, this time of five per cent. If the tax and penalties remain unpaid until the Ist of May, the property is then sold. After the sale the amount of the judgment draws interest at the rate of one per cent a month. The owner of the property is allowed three years in which to redeem his property, but in case he does this he must pay the judgment and the interest at the rate mentioned above. At the end of the three years the auditor of the county publishes for three weeks in one of the county papers the statement that the redemption period is closing. If the owners of delinquent property do not then appear and pay the judgment, the purchasers receive a tax title to the land.

So much for delinquent personal and real estate taxes. The treasurer, having collected the taxes, must now account to the county auditor for the moneys received. On the last days of February, May, and October, the treasurer makes with the auditor a full settlement of his receipts and collections for all purposes. The auditor in turn sends an abstract of the finances to the State auditor, and also keeps an account of the funds due the State, county, cities, townships, and school districts. Upon the request of any or all of these bodies he gives to them or their representatives an order on the county treasurer. The treasurer, after the days of settlement, pays over to the local governments the amounts due them. ${ }^{1}$

The State, however, has not yet received the taxes from the railroad, telephone, telegraph, sleeping-car,

1 General Statutes, $1894, \S 1576,1577$.

Settlement of treasurer's accounts. 
express, and freight companies. ${ }^{1}$ We turn, therefore, to the work of the State treasurer, who is authorized

The gross earnings tax.

by a State law to collect a three per cent tax on the gross earnings of transportation, telegraph, and telephone companies. This tax becomes due on the first day of March, and is enforced in case of nonpayment by severe methods. When the tax is delinquent the State treasurer adds a penalty of twenty-five per cent. Sometimes a company refuses to make a declaration concerning its gross earnings; in such case the treasurer fixes the amount according to the information he possesses of the business of the road, adding to the tax a penalty of twenty-five per cent. The railroad reports are due February I. About one-fifth of the State's income is derived from the gross earnings tax.

\section{The Expenditure of Public Money}

To give a government power to collect money and place no restrictions upon the expenditure of it would have been unlike the framers of American constitutions. In every State, and Minnesota is no exception to the rule, an elaborate system of law has been built up to restrain the extravagance of public officers. Thus, in the case of the State, the constitution limits the public debt for defray-

Checks on the expenditure of money. ing extraordinary expenditures to $\$ 250,000$ in the aggregate. This, however, is a slight precaution, but all money expenditures must be made by appropriation bill alone. ${ }^{2}$ In the expenditure of the

1 Constitution of Minnesota, Art. IV., Sec. 32. General Statutes, 1894, § 1676. General Lawes, 1873, ch. III, § I; 1897, chs. 159, 166, 309, 314; 1899, chs. 185, 317.

2 Constitution of Minnesota, Art. IV., Sec. 12. 
State's money the legislature has provided an elaborate system of bookkeeping. Thus all bills and obligations against the State are presented to the auditor, who issues an order on the treasurer, retaining a copy. The treasurer in turn is required to make out a daily statement of the condition of the State's moneys and present it to the auditor, so that the accounts of the two officers must be the same. The system is seen also in the local governments. The county auditors and treasurers, the city comptrollers and treasurers, and the town clerks and treasurers stand in the same relations to each other. In the county the commissioners appropriate the money, in the city and village the council, and in the township the town meeting. The legislature of the State, as the creator of these local bodies, has restricted their expenditure of money.

In the expenditure of the money belonging to the county, the commissioners are limited in two ways. In the first place the legislature has placed a limit County comupon the amount of the tax levy, so that it is impossible to tax the property holders more than a certain amount, and if the officers of a county, village, township, or city make a contract to increase their obligations beyond the amount of money produced by their maximum tax rate, such debts are null and void. ${ }^{1}$ The second restriction placed upon the county commissioners is in the issuance of bonds. Whenever such an issue is made it must be done with the consent of two-thirds of the electors.

In the cities and villages the power of regulating

1 General Statutes, $1894, \S 1639$. 
Local government powers in money matters.
City expenditures. money matters rests with the council. This body votes appropriations, but within the income of the city or village. A limit, usually five per cent of the total valuation of the property in the town or city, is placed upon the making of debts without the consent of the electors. It is, therefore, impossible for a municipal organization to burden itself with debt unless by its own consent. In the township money matters rest entirely with the town meeting, but bonds cannot be voted except with the consent of two-thirds of the electors of the township.

Under charter forms of government some general restrictions are placed by the legislature upon the extension of city debts. No appropriations of money can be made by a municipal council without a twothirds vote; in the issue of bonds a three-fourths vote must sustain the issue, and even then the question must be submitted to the people, who must ratify the issue by a two-thirds vote before the bonds can be sold. A limit has been placed upon the total indebtedness of a city, but the indebtedness may be increased beyond the five per cent limit upon the total valuation of property by the consent of two-thirds of the electors voting. A number of local bodies, such as school boards, park commissioners, and library boards, may issue bonds under certain conditions.

These restrictions, sometimes harassing, are necessary for the protection of the taxpayer. Governments are so complicated that unrestricted expenditures would mean extravagances and increased burdens of taxation. To prevent this the legislature has enacted the laws mentioned above. 


\section{CHAPTER IX}

\section{EDUCATION}

\section{REFERENCES}

Blackmar, The History of State and Federal Aid to Education, 295-7; Hyde, Minnesota School Lazos; General Statutes, i 894, ch. 36; General Lazos, 1899, chs. 101, 352, 354 ; Farmers' Institute Annual, 1899; Reports of the Superintendents of Public Instruction; Minneapolis Times, August 20, 1899.

\section{The Growth of the School System}

The history of education in Minnesota has been uneventful. Unlike Michigan and Wisconsin, the State has never been compelled to litigate the question of public support to high schools, so that the system has grown steadily from its inception. The framers of the constitution accepted thoroughly the idea of popular education, going so far as to make a positive declaration concerning the duty of the legislature to establish a general and uniform system of public schools. ${ }^{1}$ In the act organizing the Territory of Minnesota, the school system of the future State was kept constantly in view. By that act the basis of the present fund was, laid, amounting to $\$ 11,822,145$ at the end of the school year I $898 .^{2}$

The history of public schools.

1 Constitution of Minnesota, Art. VIII., Sec. I.

2 Legislative Manual, 1899, p. 261. 
Congress very generously voted two sections in each township in the Territory for school purposes, thus endowing the public school. ${ }^{1}$ With this heritage the Territory had but little to do; it has only been in more recent years that the State has sold the lands to advantage. The preliminary organization of the schools, however, rested with the legislature.

Almost the first act of the territorial legislature was to establish common schools. In November of I 849 such a system was devised, making a township in which five or more families were living a school district. The township district was changed in $\mathrm{I} 85 \mathrm{I}$

School districts.

High schools.

Normal schools. for the present school district. This method of organization was far from satisfactory to the growing towns of St. Paul, Minneapolis, Winona, Stillwater, and others, so that they requested the legislature, at different times, to make these cities special school districts. This, however, led to some abuses, and in I 865 the legislature established a third type of school district, now called the independent district.

Here and there in the State special and independent districts established high schools. Great difficulty was found in the newer communities in sustaining these forms of higher education. The State therefore considered it advisable to extend aid, which it did for the first time in I88I. Since then this high school act has been much modified, as will be seen in a later paragraph.

Regarding the high school as the second link, the third one in the State educational system is the normal school. The framers of the constitution recognized the necessity of specially trained teachers. In

1 Act organizing the Territory of Minnesota, Sec. 18, Appendix G. 
I 858 provision was made for the location and establishment of three normal schools, a fourth one was created in 1885 and established at Moorhead, and a fifth at Duluth in 1895 . The three earliest schools did not really get well established until 1870 .

The University is the crown of the entire school system. It was established by legislative enactment as early as $185 \mathrm{I}$, but was reorganized in 1860,1864 , and 1868. In the first year mentioned, Congress granted The University.

to the Territory two townships of land for the use and support of a university. A school was organized in I $85 \mathrm{I}$, which was continued until I 854 ; two years later the title passed out of the hands of the regents. It was in 1854 that the present site was secured. The old stone building was completed in 1858 , but the vicissitudes of the University were so great that finally, in 1864 , the legislature appointed a committee, consisting of John S. Pillsbury, John Nichols, and O. C. Merriman, to pay the debts and sell the building and lands. Through the tact and energy of these men the University was saved. In I 867 a preparatory school was opened, but another reorganization was necessary before the institution was fairly started. The act of 1868 created a governing body of nine regents and established five collegiate departments. Dr. William W. Folwell was chosen president in 1869 . He was succeeded in 1884 by the present president, Dr. Cyrus Northrop.

\section{The Organization of the School System}

Three forms of school districts are now established by the law. These are the common, independent, 
School districts.

Common schools.

Independent districts. and special districts. All are bodies corporate, possessing the power to sue and be sued, and the right to make contracts. In the use of these powers the districts differ very considerably. We shall therefore examine them in order.

The common school district is an area of territory including less than five hundred people. When a majority of the freeholders who are legal voters make known by a petition to the county commissioners their desire to have a school district in a particular part of a county, the commissioners grant the request upon the approval of the county superintendent of schools. The organization of the district rests with the district meeting. This as a usual thing is held once a year, the time set by statute being the third Saturday in July. At this time the meeting determines the length of the school year, the amount of the tax, the site of the schoolhouse, and elects officers. The officers in the case of the common district are a director, a treasurer, and a clerk, elected for a period of one year. This board controls the school affairs of the district, and hires and pays teachers. Such a school board may issue bonds for school purposes upon the consent of two-thirds of the voters present at the annual meeting.

The independent district is not as democratic in its organization as the one just referred to. Its affairs are in the hands of a board of education consisting of six men elected by the people. The board has power to erect school buildings and to issue bonds when authorized to do so by the people. It controls directly the election of the superintendent, the question of grades, the selection of teachers, and the regulation of 
the schools. The board did have, at one time, the power to appoint commissioners to examine candidates for teachers' certificates, but that power now rests with the State superintendent of public instruction and the county superintendent. ${ }^{1}$

Owing to the large population in the cities, a third form of district has been created, called a "special district." The general school laws do not appear to be Special sufficient to meet all the questions that come up in the management of city schools, and, in consequence, the legislature has established, in the cities of St. Paul, Minneapolis, Duluth, Winona, and other towns, boards of education with wider powers. There is no special uniformity in their organization. The usual powers found in the independent school district are retained, with other features added. The electors in the special districts select, at the regular city election, from two to four members of the board of education for a term of two or three years. The powers conferred upon the boards render the office an important and responsible one. ${ }^{2}$

It is under the direction of the boards in the school districts that the schools are graded and grouped into primary, graded, and high schools. An elaborate system of control and direction has been built up in Grading of order to keep the work uniform and even, but this must be left for consideration in another section. Meantime, our inquiry brings us to another important matter, the support of the schools.

1 General Lazws, 1899, chs. Ior, 354.

2 In 1898 there were 6415 common, 151 independent, and 25 special districts. In these were enrolled $324,65^{\circ}$ pupils. 


\section{The Support of the Schools}

The money necessary for the support of the public schools comes from two sources, - interest on the School funds. school fund and taxation. As already noted, Congress gave to the Territory of Minnesota two sections in each township for school purposes. By judicious sales a fund amounting to nearly $\$ 12,000,000$ has been built up. The fund is composed of receipts from the land sales, sale of timber, mineral leases, and royalties on iron ore. ${ }^{1}$ The proceeds from these various sources are invested in bonds, or loaned to counties and school districts to be used in the erection of county or school buildings. The income is distributed to the various counties in proportion to the number of scholars enrolled. The second source is taxation in the form of state, county, and special taxes.

There is annually levied upon all the taxable property of the State a tax of one mill on the dollar. This is known as the "one mill school tax," and the School taxes. collections from this source are added to the income from the school fund. The total, amounting to over $\$ 1,000,000$, is distributed by the State auditor to the different counties. As a further provision for the support of the schools, a tax of one mill is levied in the counties. This is paid into the county treasury (as are all local taxes), and returned in the final settlement to the districts from which it is collected. Usually the apportionment from the State fund and the local tax are not sufficient to meet the school - expenses, so a third tax is levied called a special school tax. The needs of the district cause the last 
tax to vary a great deal. The amount of the State and local tax is fixed by law, but the special tax rate is determined by the school meeting in the common districts, and by the boards of education in the independent and special districts. The expenses of the normal schools, teachers' institutes, training schools, and the department of public instruction are met by appropriations granted by the legislature.

The University, like the public schools, was endowed with a gift of land by the Enabling Act. Congress had made one grant of two townships in $185 \mathrm{I}$, but this had been lost in an effort to found a university, so in the enabling act a second grant was made. Again, in 1862, Congress, by the Agricultural Land Grant Act gave each State a quantity of land for a mechanical and agricultural college. This grant, in 1868, was turned over to the regents of the University. From the sale of these lands a permanent university fund has been created, amounting, in 1898 , to $\$ 1,202,893$. There still remains to be sold 46,936 acres of land belonging to the original grants. In addition to the interest from the permanent fund, the University receives $\$ 25,000$ annually from the government of the United States, the proceeds from the $\frac{3}{2} 0$ mill tax on the property in the State, fees from the students, and the proceeds from the sale of the products of the University farm. The legislature appropriates from year to year $\$ 60,000$ to $\$ 70,000$ for repairs and new buildings. It is well equipped with buildings, now numbering thirty. The income of the University at present is about $\$ 380,000$. 


\section{Administration of the School System}

Division of the schools.

The rural school.
Aids to rural schools.
For the purpose of proper management the school system is divided into three parts: the public schools, normal schools, and the University. The first of these groups is again subdivided into rural, State graded, and State high schools. The rural school is the common school found throughout the State in the agricultural districts. A board of three persons elected by the school meeting hires the teacher and conducts the financial affairs of the district. In each county there are a number of such schools, in which from twenty to forty pupils are instructed in the elements of education. To keep these in touch and at the same time maintain a certain standard of efficiency an officer, called the county superintendent, is elected in each county every two years. His duty is to examine and license teachers, under the direction of the State department of public instruction, visit and inspect the schools of the county, and give such advice as is needed. ${ }^{1} \mathrm{He}$ also conducts each year a county institute, and makes an annual report to the State superintendent of public instruction and the county auditor. The latter report finally finds its way to the State auditor, and is the basis of the distribution of the school fund to that county.

To encourage the development of the rural schools the legislature, in I899, passed an act granting yearly to such schools as meet certain requirements the sum of $\$ 75$. In order to secure this bonus the school trustees must provide for eight months of school, a school building and library, and hire a teacher who

${ }^{1}$ See p. 149, and General Laws, 1899, ch. 10. 
has a first-class certificate. ${ }^{1}$ When the schools in a county have complied with the regulations, application is made to the county superintendent, who certifies to the correctness of the application. The papers are then sent to the State superintendent, who makes the apportionment in accordance with the law.

It is seldom that a school reaches the dignity of a graded school until it is organized as an independent district. There is no demand in a rural community for a graded school, but a population of five hundred or over in the district makes it desirable to grade the pupils. An organization of this kind requires a larger expenditure of time and money. It is usually necessary to have a special superintendent to look after the interests of the schools, and to employ a larger number of teachers. The independent and special districts are not, therefore, subject to the direct supervision of the county superintendent. The legislature, recognizing the good work done by the graded schools, made provision for State aid. But there are some schools only partially graded; to these, if they have eight months of school, two departments, at least one teacher with a first grade certificate, buildings, and a small library, $\$ 100$ is granted annually. The application is made in the same way as in the case of the rural schools. The fully graded schools receive $\$ 200$ a year, but the requirements are very much greater. It is necessary for them to have nine months of school, four departments (the principal being a college graduate), buildings, library, and a regular course of study.

The ambition of every high school is to become

1 General Laws, 1899 , ch. 352. 
State high schools.
The high school board.

a State high school. The legislature early recognized that the expense of conducting a first-class high school rests heavily upon a small and energetic community. In I88I an act was passed to meet this difficulty. The legislature of I899, however, surpassed all records, and provided generously for State aid to high schools. Under this act, if a high school maintains regular courses admitting to the University, nine months of school, charges no tuition, and has proper buildings and a library, it may receive from the State the sum of $\$ 800$ annually. Such aid is limited to five schools in the same county. These schools are always open to the visits of the high school inspector, and are subject to the regulations of the high school board. The application for aid is made to the latter body.

Possibly the most important part of the machinery of the public schools is the high school board. The law first provided for this board in 1878 , but the present membership was established in $188 \mathrm{I} .^{1}$ The opening paragraph of the law reads, "The governor, superintendent of public instruction, and the president of the University of Minnesota, ex officio, are hereby constituted a board of commissioners on preparatory schools for the encouragement of higher education in this State." This board is given great discretionary power in the regulation of the schools receiving State aid. The board also causes to be visited each school receiving aid from the State. Two inspectors are employed for this purpose, one with the title of Inspector of State High Schools, the other with the

1 General Statutes, 1878, II., ch. 36, § 155. General Laws, 188I, ch. 144, § I. 
title of Inspector of State Graded Schools. The recommendations made by these officers from time to time have been extremely helpful in making the school system more uniform. Under the authority of the board, examinations on the various subjects pursued in a high school are given twice a year. The papers are submitted to the examiner of the board and marked. The pupils receive cards for each subject in which they pass; these, as far as they go, are prima facie evidence that the requirements for admission to the University have been met.

The head of the public school system is the superintendent of public instruction, who is appointed by the governor for a term of two years. ${ }^{1}$ His duties Superintendent of public inare numerous; among these are meetings with the county supcrintendents of congressional districts, the organization of training schools and teachers' institutes, the preparation of blanks for school reports, the holding of examinations for teaching certificates, and the presentation of an annual report showing the number of pupils in the schools, the condition of the public schools, the amount of the school fund and how distributed, and such other matters as relate to his work. ${ }^{2}$ The State superintendent is, by virtue of his office, a member of the high school board, the normal school board, and the University regents.

The law of 1899 (Ch. IOI) has placed an additional burden upon the State superintendent. The irregularities in the granting of teachers' certificates demanded some adjustment, and the law just referred Teachers' to attempts to obviate the difficulty by placing the certificate.

1 Appendix L.

2 General Statutes, $1894, \$ 3724$. 
granting of certificates jointly in the hands of the State and county superintendents. Five different certificates may now be issued. The State superintendent issues two forms of first-grade certificates, both for a period of five years, one upon examination, the other without. Examinations are held twice a year in every county, the papers for the State examinations being sent to the State superintendent for marking. In the cases where a high grade of scholarship is shown and the candidates have taught for eight months, the certificates are issued for five years, provided the county superintendents can vouch for the character of the candidates. The other first-grade certificate is given to persons who have taught five years in the State and are recommended by a board of education and a city or county superintendent. A second-grade certificate is issued under the same conditions, except that it is for a term of two years and after an experience of five months in teaching. These certificates are good in any county of the State.

Certificates issued by the county superintendent.

The other two certificates are issued by the county superintendents. One is called a limited secondgrade certificate, and the other a third-grade certificate. The second-grade certificate is issued to those who have passed successfully the State examinations, but who have never taught. Such a certificate is good for one year in the county in which it is issued. The third grade is issued by the county superintendent upon his own examination, but is good only in a single district in the county. The law forbids the county superintendent to issue this certificate to the same person more than twice. The object of the law 
is to secure better qualified teachers; that it will do this cannot be doubted.

\section{Normal Schools}

This grade of schools was established to educate and prepare teachers for work in the public schools of the State. Various acts of the legislature have created five schools in which are maintained three different courses of study - an elementary course, an advanced course for high school teachers, and a professional Courses. course equivalent to about two years' work in the University. In addition to these courses instruction in kindergarten methods is given. Each of the schools maintains a model school for purposes of demonstrating practically the work of scientific teaching. The attendance has been large during the last ten years. ${ }^{1}$

The management of the normal schools is in the control of a board of nine persons appointed by the The board. governor. The term of office is four years. The law describes the powers of the board as follows: "The State normal school board shall have the general supervision, management, and control of the State normal schools, and of all property, real and personal, thereto appertaining. They are hereby authorized and empowered to contract for the erection of all buildings connected with the schools under their charge, to appoint all professors and teachers in said schools, and to fix the salaries of the same." 2 The board is also given the power to prescribe and regulate the

1 Legislative Manual, 1899, pp. 290-297.

2 General Statutis, § 3839. 
courses and conditions of admission. At the end of each year a report is made to the governor, setting forth the condition of each school. At the head of each school is a president, who manages its affairs so far as instruction and discipline are concerned.

\section{The University}

In another paragraph of this chapter the early history of this institution was briefly described, so that the organization and government alone will be the subject of this section. The amended acts of 1868 and 1872 , as well as later ones, provided for the establishment of five or more colleges in the Univer-

Departments and degrees. sity of Minnesota. At the present time there are colleges of science, literature and the arts, mechanical engineering, medicine, dentistry, law, agriculture, schools of mines and chemistry, and a graduate department. From these schools and colleges the degrees of bachelor of arts, science, literature, agriculture, engineering, and law are given upon the completion of undergraduate work. Other degrees, such as doctor of medicine, master of arts, and doctor of philosophy, are awarded to candidates completing advanced courses. The University does not confer any honorary degrees.

A close relation exists between the University and the public schools. It is the ultimate goal toward

Relation of schools to the University. which the courses of study in the public schools lead. The high schools act as feeders to the higher institutution. Recognizing the desirability of such a relation, the entrance requirements to the University are made the basis of much of the high school work. A 
system of accredited schools has been created, so that a pupil from a high school which has been inspected and approved may be admitted to the University upon presentation of his diploma. Such schools as are not accredited may secure credits for their students by the presentation of State high school board examination certificates to the University authorities. ${ }^{1}$

The government of the University is vested in a board of twelve regents, of which the governor, the State superintendent of public instruction, and the The board of president of the University are ex officio members. The remaining nine members are appointed by the governor for a term of six years. Because of the great services of Hon. John S. Pillsbury to the University, he was made a life regent, thus increasing the board to thirteen during his lifetime. This body elects from its members a president of the board, a treasurer, and a recording secretary. The last two need not be members of the board. The president of the board and the treasurer give bonds to the State of Minnesota in the sums of $\$ 50,000$ each for the faithful performance of their duties.

The regents have power to enact by-laws for the government of the University, to elect a president, the requisite number of professors, instructors, officers, Powers. and employees, fix salaries, regulate the courses of study, confer degrees, hold property, and dispose of the same. The regents also have charge of the agricultural farms and experimental stations established under congressional grants. The president of the University holds his office during the pleasure of the board. The administration of the affairs of the

1 See State high school board, p. 148. 
institution rests with him. Two reports are required from him, one to the regents, the other to the superintendent of public instruction.

The geological survey.

In 1872 the legislature provided for a geological and natural history survey of the State. The direction of this undertaking was left in the hands of the regents. Funds were to be provided by the sale of the "salt lands" transferred to the regents. The purpose of the survey was to secure a complete account of the animal, mineral, and vegetable kingdoms in the State. Reports of the work done were authorized, and these have appeared from time to time in quarto volumes.

6i. Farmers' Institutes, Free Text-Books, And LIBRARIES

There have grown up in the Minnesota system of education a number of features which cannot be treated within any orderly scheme, such as the farmers' institutes, school libraries, and free textbooks. It is necessary, therefore, to consider these in

Farmers' institutes. a paragraph by themselves. The farmers' institutes are a most interesting part of the educational work. Since I89I the legislature has made an annual grant of $\$ 10,000$ for their maintenance. The object is to disseminate practical knowledge upon questions pertaining to agriculture, horticulture, stock, and dairy farming with the least expense and inconvenience to the people of the State. The administration of the system is intrusted to a board consisting of two regents of the University, the director of the experimental station, and the presidents of the State 
Agricultural Society, State Dairy Society, and the Horticultural Society. The members hold office for three years and are given power to employ a superintendent of institutes. This officer has charge of the institute programmes, the securing of instructors, and the publication of the Farmers' Institute Annual. He also makes a report of the attendance, character of the work, and expenses to the administrative board. 1 The work of the institutes has been very helpful to the farmers of the State, and must produce great results in a few years. The first act in relation to the institutes was passed in 1887 ; since that time it is required that at least forty such institutes must be held each year.

The State legislature has never deemed it wise to undertake the publication of free text-books, although bills for that purpose have been introduced from time to time. Nevertheless, an act was passed as early as 1887 , and since amended, giving school Free textdistricts the power to make contracts with publishers with the expectation of loaning books free of charge, or selling them at cost. In this law there are two or three steps to be noted. First, the act provides for the filing with the superintendent of public instruction of lists of books and the lowest prices at which the publishers are willing to sell them to any board of school trustees in the State. ${ }^{2}$ Copies of the books listed must be deposited in the office of the department of public instruction. The second step rests with the superintendent of public instruction, who, after receiving the lists and the copies of the book,

\footnotetext{
1 Legislative Manual, 1899, pp. 340-342.

2 Curryer vs. Merrill, 25 Minn. I.
} 
sends a certified pricelist to the clerk of each common school district. The final step is determined by the legal voters of the district. Five or more legal voters may petition the trustees to submit the question of free text-books to a vote. After ten days' notice a meeting may be held to decide the question. If a majority vote in favor of free text-books, it is the duty of the trustees to provide for the same. The legislature enacted that contracts might be made with publishers for periods of from three to five years. ${ }^{1}$

School

For the purpose of encouraging school libraries libraries. the legislature appropriated, in 1887 , the sum of $\$ 10,000$, which was to be distributed as follows: The presidents of the normal schools and the superintendent of public instruction were directed to select a suitable list of books for use in schools. When this was done they were to advertise for bids on the books and to make a contract with the publishers for a term of two years. When any school district purchases all or part of the books noted on the list and provides for their care, the State auditor, upon the recommendation of the county superintendent to the superintendent of public instruction, shall issue a warrant for not more than $\$ 20$ for the first statement, $\$$ I 5 for the second, and $\$ 5$ for each subsequent statement. ${ }^{2}$ Each school may receive from the State only one payment in each year.

The crowning act of the legislature in rounding out and completing the educational system of the Travelling libraries. State was the creation of travelling libraries. By an act passed in 1899 a commission of five persons was created, consisting of the president of the University,

1 General Statutes, 1894, §§ 3896-3901.

2 Ibid., § 3716 . 
the superintendent of public instruction, the secretary of the Minnesota Historical Society, and two members appointed by the governor for six years. ${ }^{1}$ The board is to buy books and provide for their circulation throughout the State. The legislature appropriated $\$ 5000$ annually for this purpose.

It will thus be seen that Minnesota has a remarkably well-developed system of public education. This system provides not merely for instruction in the school- Conclusion. room, but comprises also institutes, school libraries, and circulating libraries. The machinery is now well organized; time alone is needed for the full growth of the educational work.

General Laws, 1899, ch. 353. 


\section{CHAPTER $\mathrm{X}$}

\section{THE PROTECTION OF THE STATE}

\section{REFERENCES}

General Statutes, 1894, ch. 35 ; General Lawe, I897, ch. I1 8, 1899, ch. 23I ; Legislative Manual, 1899 (Index); Reports of the Adjutant General and of the Superintendents of Institutions in the Executive Documents published every two years by the State.

\section{The Problems}

The commonwealth of Minnesota is a part of society united politically, industrially, and socially. The whole study of this book has been given aver to the political side of this organization; nevertheless, the industrial and social functions of the commonwealth are just as important as the political, although left more to the individual, who arranges his industrial and social relations to suit himself. So long as the actions of the individual are not contrary to law, there is no interference on the part of society. But among every people exist certain persons who refuse to conclasses. form to the laws of society. These must be prevented from interfering with the property and the affairs of the law-abiding. Then there are others who, through misfortune, have become paupers, or others, defective by birth or other causes, who need protection, so that the State finds it necessary to help them. Sometimes a body of citizens, feeling that they have 
been wronged, usually in some industrial affair, break out in revolt against the government and refuse to await the action of the courts, preferring to take the law into their own hands. Such an act requires the use of force. This necessitates the existence of a body of militia to prevent the infraction of law by force of arms. Another reason for the existence of the militia is the need of a national body of citizen soldiery for use in any emergency, State or national. Thus it will be seen that the State has two problems before it in protecting society; the first and larger is correctional and charitable in its character, the second, military. The first question deals with the housing of dependents, the care of defectives, the reform of youthful offenders, and the imprisonment of criminals. The State has recognized fully its duty in reference to these four classes, and in consequence a number of institutions have been created to meet this need. These may be grouped as follows:-

Classification of institutions.

CHARITABLE AND CORRECTIONAL INSTITUTIONS

I. Dependents.

I. School for Dependent and Neglected Children.

2. Soldiers' Home.

II. Defectives.

I. Insane Asylums.

2. Deaf, Dumb, and Blind Institutes.

III. Youthful Offenders.

I. State Reform School.

2. The State Reformatory.

IV. Criminals.

I. State Penitentiary. 
The second problem involves the maintenance of order under all circumstances. To some degree this The militia. requires a military force. The unorganized militia consists of all male persons between the ages of twenty-one and forty-five who are residing in the State.

The organized militia is composed of companies and regiments formed under the authority of the United States and of the State. The governor of the State may call out the State militia, and the President of the United States the entire national guard for three causes, - to execute the laws of the State or

Organized militia. the United States, to suppress insurrections, or to repel invasions. The Constitution of the United States gives Congress the authority to provide for the organization of militia in the different States. ${ }^{1}$ In order to encourage the States to organize militia, an appropriation is made by Congress which is distributed among the different States in proportion to the men enlisted. The legislature also makes provision for the militia, but even with this financial aid the members of the militia often find it necessary to contribute to the support of their respective companies. In some of the States naval reserves are organized. This force stands in the same relation to the navy that the militia does to the army.

The two problems of protection, which are quite as important as those of education, are before us, and we shall consider them in the following order: charitable and correctional institutions, the militia, and naval reserves.

1 Constitution of the United States, Art. II., Sec. 8, and Art. II., Sec. 2. 


\section{Charitable Institutions}

The inmates of these institutions are to be distinguished from those in the correctional institutions. Dependents. They are here because of misfortune or inability to maintain themselves in the outside world. As shown in a previous paragraph, there are two groups, one for dependents, the other for defectives. There are only two institutions for dependents, the School for Dependent and Neglected Children, and the Soldiers' Home.

The School for Dependent and Neglected Children is situated in the city of Owatonna and was established there in 1885 . In the following year the school was opened for the reception of children. The permanent buildings are eleven in number and comprise an administration building, a schoolhouse, heating plant, seven cottages, hospital, and barns. The total cost of the property was $\$ 203,743$. The object of the institution is to provide a temporary home for the dependent and neglected children of the State. ${ }^{1}$ The plan of administration embodies the features of a home life. The children are divided into families numbering from twenty to thirty members. Each family occupies a separate cottage and is in charge of a competent woman. The county commissioners of each county are authorized by the State law to send dependent or neglected children to the home after an examination before the judges of probate. In this way the State keeps in touch with all its parts, and is able to carry out the benevolent purpose of the school.

1 Legislative Manual, 1899, pp. 309-310. 
The Soldiers' Home.

Management.

The care of the insane.

The Soldiers' Home was established by legislative act in I887. It was located near the historic Minnehaha Falls. The object of the home is to provide a refuge for all honorably discharged soldiers, sailors, and marines who served in the wars of the nation, and who are not able to earn their living and have no adequate means of support. The property owned by the State for this purpose consists of fifty acres of land and nine permanent buildings. The cottage system is followed as the best method of housing and maintaining discipline. The expenses of the home are met by the "home support fund," which consists of (I) moneys transferred from the soldiers' relief fund, (2) the annual payment by the United States government of \$IOO for each inmate, (3) payments by pensioned inmates of all moneys received by them from the government over and above the sum of four dollars a month.

The management of the home is vested in seven trustees, who are appointed by the governor for a term of six years. This board is non-partisan; no more than four can be of the same party. The commander of the home is selected by the trustees.

The State has three insane hospitals, situated at St. Peter, Fergus Falls, and Rochester. By the legislative act of April I 5, I 899, two asylums were established at Anoka and Hastings, which will be built during the year. ${ }^{1}$ January I, I899, there were 3357 persons in the insane hospitals. The cost of maintaining them, together with the expenses of administration, was about $\$ 1,000, \infty 00 .^{2}$

1 General Laws, 1899, ch. 230.

2 Legislative Manual, 1899, p. 300. 
The control of the asylums and all the matters pertaining to them is in the hands of a board of five trustees appointed by the governor. The term of office is three years. It is their duty to examine the Management by condition of the institutions, to ascertain their needs, and regulate the expenditures. The board appoints the superintendents of the asylums under its care.

At Faribault are situated the institutions for the defectives. These consist of schools for the deaf and dumb, blind, and feeble-minded. The legislature as early as 1858 made provision for a State institute for defectives. The school, however, was not Institute for defectives. opened until 1863. The first building was erected five years later. As the school grew in size the difficulties in training the blind and deaf and dumb together grew more and more apparent. To obviate this the legislature established three separate schools now known as the schools for the deaf and dumb, blind, and feeble-minded. Each school is governed, so far as instruction and discipline are concerned, by a superintendent and assistants. The business affairs of the schools, the matter of buildings, and the employment of officers are in the hands of a board consisting of the governor, five other persons appointed by him, and the superintendent of public instruction.

\section{Correctional Institutions}

The problem of the State under this head is a defensive and correctional one. The individuals with whom it deals are not defectives, but are breakers of the law. In order to meet the problem of offenders 
State institutions.

against the law, the State has established three institutions, two of which are for youthful offenders. One of these, the State training school at Red Wing, is for boys and girls under sixteen years of age. The second, the State reformatory at St. Cloud, is for boys and men between the ages of sixteen and thirty. The third institution, the penitentiary at Stillwater, is the State's prison for criminals.

The Minnesota State training school was established at St. Paul in I866. The crowded condition State training school.

of the institution and its nearness to the city compelled its removal to Red Wing in I895. The object of the school is to train incorrigible children and youthful offenders. The school is organized on the open family plan. The families are graded according to the age of the children, and are in charge of a manager, teacher, and housekeeper. The boys are taught trades and the girls are given instruction in housework. A State agent of the school finds homes for the children in the various parts of the State. A board of three persons, appointed by the governor for a period of six years, has general control of the school's affairs. The cost of the buildings constructed at Red Wing up to I899 was $\$ 307,000$. The expense of maintenance is $\$ 165$ per child.

Immediately between the State School and the Reformatory. State prison is the reformatory. Boys and young men between the ages of sixteen and thirty, never before convicted of a crime, are sent here for reformation. The reformatory is situated at St. Cloud, where it was established in I887. The object of the institution is to place first offenders under such discipline and education as will enable them to form habits and 
character suitable to meet the problems of honest self-support. The men who are sentenced to the reformatory do not enter the institution for any definite time, but are retained until reformation is strongly probable. When allowed to leave the institution the release is not final, but such persons, after a period of good conduct, may be paroled. The paroled prisoner must report to the prison authorities for a period of several months. The reformatory is under the control of a non-partisan board of six men. One member of the board is appointed each year by the governor. The board elects the superintendent, who appoints his subordinates. In the training of the men and boys an effort is made to teach them some useful trade before they leave the institution. On this point the superintendent says, "Eighty per cent of the inmates are growing boys, sixteen to twenty-four years old, hearty eaters and hard on clothes, and, as they come without trades and are mostly undisciplined to labor or otherwise, and as soon as fitted go out for themselves again, their cost to the State is much more than their earning capacity. The object is reformation, and if that is accomplished and due economy exercised, the State is well served." 1

The State prison was the second institution provided after the organization of the Territory. The buildings of the prison were begun in 1851 . Since State prison. that time the prison has been entirely rebuilt. The shops alone now number seven. The following quotation depicts clearly the workings of the prison system: "The discipline and management of the prison 
is equal to the best in the country; every feature of advanced penal management is in full operation, the State laws allowing diminution of sentence term for good conduct. An evening school is conducted for the benefit of inmates eight months in the year, a Chautauqua circle is well attended by the inmates, and a well-organized choir of inmates furnishes music for Sunday services and holiday entertainments. The Prison Mirror, a weekly newspaper, is published and edited by the inmates, who have full control. The prison has a well-selected library of five thousand volumes, which are freely circulated among the prisoners. The parole and grading systems, which have been in operation for seven years, are satisfactory. . . . The paroled prisoner is looked after by a State agent, whose duty it is to assist the discharged prisoner in securing employment and to have a watchful care that the conditions of parole are not violated." 1

Employment of prisoners.

The inmates of the prison are employed in a number of industries. These are the making of binding twine, school supplies, and the manufacture of shoes. The profits to the State from the business done have been something like $\$ 20,000$ a year. The affairs of the prison are very largely in the hands of a board of prison managers. The members are five in number, serving for terms of five years. The board appoints the warden without term.

In connection with the State prison, the legislature

Board of thought it necessary to establish a board of pardons, pardons. which was done in $1897 . .^{2}$ Previous to the passage of this law, the power of releasing prisoners rested 
entirely with the governor. The new board consists of the governor, the chief justice of the supreme court, and the attorney general. The power to grant pardons and to commute the sentence of any person convicted of any offence against the laws of this State now rests with this board. Regular meetings are held on the second Mondays of January, April, and July, at which time written applications for pardons are made. A majority of the board determines the fate of the applicant.

\section{The Board of Charities and}

CoRrections

A general board of supervision was created in 1883 , to act as a sort of check upon the managements of the various charitable and correctional institutions. The board consists of six persons, not more than Membership. three of whom shall be from the same political party. No compensation, beyond expenses, is given to the members of the board. Two members are appointed each year for three years. The secretary of the board, a most important officer, is appointed without term.

In the law itself, the duties of the board are defined as follows: "To investigate the whole system of public charities and correctional institutions of the State; examine into the condition and management thereof, especially of prisons, jails, infirmaries, public hospitals, and asylums ; and to secure accuracy, uniformity and completeness in statistics of such institutions, the board may prescribe such forms of report and regis- Duties. tration as they may deem essential, and all plans of new jails, lock-ups, and infirmaries shall, before the 
adoption of the same by the county authorities, be submitted to the board for criticisms and suggestions. The governor, in his discretion, may, at any time, order an investigation by the board, or by a committee of its members, of the management of any penal, reformatory, or charitable institution of the State." The board also makes a report to the legislature biennially. In the report are set forth the expenses, and the condition of the State institutions, together with such suggestions as may seem desirable.

Cost of

The State spent during $1896-98$ the sum of institutions. $\$ 2,829,723$ for the support of the charitable and correctional institutions. The number of inmates at the time was $567 \mathrm{I}$, which made one inmate to every 306 people in the State. The cost of maintenance per inhabitant was $\$ 1.63$. These are rather remarkable figures. Compared with $\mathrm{I} 880$, it means a decided increase in number of inmates and expense of management. The work of the board, nevertheless, has been particularly helpful in securing uniform prison conditions throughout the State.

\section{The Militia}

The military problem of the State, such as it is, remains to be considered. The Spanish War disturbed very considerably the national guard organization existing in the various commonwealths. This was particularly true of Minnesota, for the enlistment of the militia in the volunteer army of the United States nearly wiped out the militia organization for the time being. The military code of the State, as already pointed out, declares that all able-bodied 
persons between the ages of twenty-one and fortyfive are subject to military duty, ${ }^{1}$ and the assessors are instructed to enroll all such persons within their districts. Two lists are made out, one of which is sent to the city or town clerk, the other Unorganized militia. to the county auditor. The latter officer corrects the list and sends it to the adjutant general. There are some exemptions from service, thus, (I) all persons exempted by the laws of the United States; (2) persons in the army, navy, or volunteer service of the United States; (3) ministers of the gospel; (4) Indians not taxed, idiots, lunatics, and persons who have been convicted of an infamous crime are free of military duty. In time of war the adjutant general may use the lists prepared by the assessors for drafting purposes. This officer is the custodian of all records, books, papers, and accounts of Adjutant the military department of the State. He has a general supervision over the military stores, and performs all other duties required of him by the commanderin-chief. The adjutant general is also the claim agent against the United States government for all persons who have claims for pensions, back pay, bounties, or other compensation arising during the Civil War.

The national guard in time of peace consists, to quote the statute, of the commander-in-chief and staff, three regiments of infantry and one battalion of artillery, formed into one brigade, and one medical corps. The brigade consists of one brigadier general and staff, three regiments of infantry, and one battalion of artillery. The organization of the brigade may Organizabe seen in the following diagram:-

general.

1 Military code, General Laws, 1897, ch. 118. 


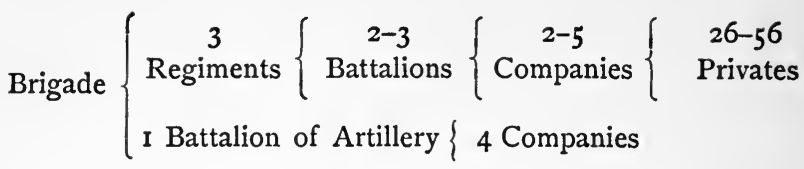

In time of war the commander-in-chief has power to increase the force, and to organize and equip it as the exigencies of the case may require.

Enlistment.

Enlistments in the national guard are made for a period of three years. The recruits sign a musterroll and an enlistment paper, the latter containing an oath of allegiance to the State and the United States. Reënlistments may be made for a shorter term. Each year the various companies are mobilized at some convenient point for regimental or brigade manœuvres. At such times the privates receive a compensation of $\$ 1.50$ per day. From this is deducted the sum of fifty cents for sustenance, but the State furnishes food, transportation, and tents. The officers receive a higher compensation, the maximum being $\$ 2.25$ per day. In actual service, so long as they are under the authority of the State, the pay of privates is $\$ 2.00$ per day, while the officers receive the same compensation as officers of similar rank in the army of the United States.

The military code provides a series of courts for the trial of charges and offences against military law Military and custom. These courts are:courts.

(I) Courts of inquiry

(2) General courts martial

(3) Regimental courts martial

(4) Summary courts $\left\{\begin{array}{l}(a) \text { Field officers' courts } \\ (b) \text { Company courts }\end{array}\right.$ 
Before these courts the charges must be brought in writing with specifications, which must be approved by a different commanding officer for each court. If approved then follows arrest, summons, and procedure to trial and finally the verdict and sentence. ${ }^{1}$ These and other regulations are seemingly necessary for the discipline of large bodies of men.

The expenses of the national guard are largely Expenses. met by the State. The arms, uniforms, accoutrements, and ammunition are provided from this source. The erection, leasing, or renting of armories for troops is a municipal matter, and rests with the city councils.

\section{The Naval Reserve}

The legislature of 1899 authorized the formation of eight divisions of the naval reserve. These are to be Naval divided into two crews, known as the first and second crews of the naval reserve of Minnesota. The naval reserve is commanded by an officer appointed and commissioned by the governor. Each ship's crew is commanded by a lieutenant-commander appointed and commissioned in the same way.

The organization of the reserve conforms to the provisions of the laws of the United States and the Organization. system of discipline used in the United States navy. No appropriation was made for the organization; the State relies upon the Federal Government to supply the equipment and the instruction. The naval reserve, as the militia, is under the command of the governor, and may be called into active service in time of war, riot, or insurrection.

1 Military Code, Part II., Art. II., General Laww, 1897, ch. 118. 
Government is the agent of the State, established to carry on public works, insure justice, and provide for the common defence. In this book we have seen the organization, the machinery, and the working of the government of the Commonwealth of Minnesota. It is all a means to an end, that end being to increase the possibilities of human happiness and comfort. 


\section{APPENDIX}

\section{$A$. GOVERNORS OF MINNESOTA}

\section{TERRITORIAL}

Alexander Ramsey. . . . . . . 1849-1853

Willis A. Gorman . . . . . . . 1853-1857

Samuel Medary. . . . . . . 1857-1858

\section{State}

Henry H. Sibley . . . . . . . 1858-1860 Alexander Ramsey . . . . . . . 1860-1864 Stephen Miller . . . . . . . . 1864-1866 William R. Marshall . . . . . 1866-1870 Horace Austin . . . . . . . . 1870-1874 Cushman K. Davis . . . . . . . 1874-1876 John S. Pillsbury . . . . . . . 1876-1882 Lucius F. Hubbard . . . . . . 1882-1887 Andrew R. McGill . . . . . . . 1887-1889 William R. Merriam . . . . . . 1889-1892 Knute Nelson . . . . . . . . 1892-1895 David M. Clough . . . . . . . 1895-1899 John Lind . . . . . . . . . 1899-1901 Samuel R. Van Sant . . . . . . 190I- 


\section{B. MEMBERS OF THE FIRST LEGISLATURE OF MINNESOTA}

[For membership list of the second and third legislatures see Neill, History of Minnesota, 546-564.]

Met September 3, I849, Central House, St. Paul

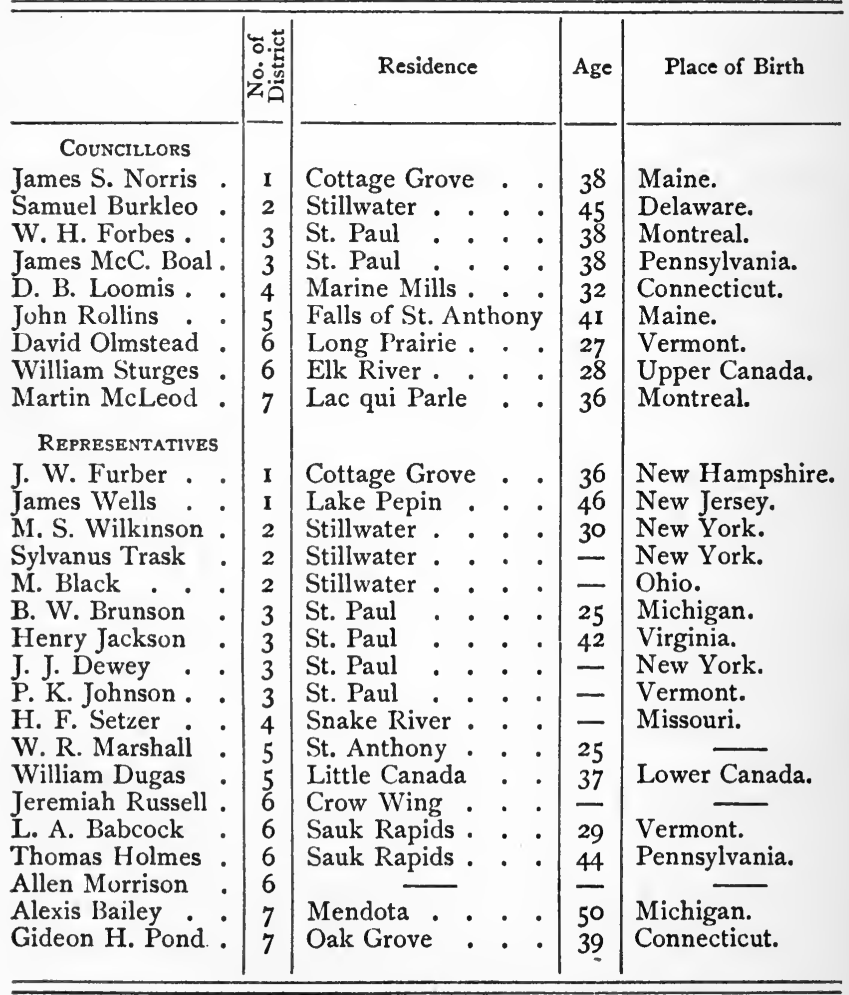


c. POPULATION OF MINNESOTA IN 1849

\begin{tabular}{|c|c|c|c|c|c|c|c|}
\hline \multicolumn{3}{|c|}{ County Seats } & \multicolumn{2}{|l|}{ Counties } & Males & Females & $\begin{array}{l}\text { Vote } \\
\text { for } \\
\text { Dele- } \\
\text { gate }\end{array}$ \\
\hline St. Paul . & - . & & Ramsey . & . & 976 & 564 & 273 \\
\hline Stillwater . & . . & . & Washington & . & 821 & 291 & 213 \\
\hline Sauk Rapid & ds. & - & Benton . & • & 249 & 108 & 18 \\
\hline \multirow{2}{*}{ Mendota } & \multirow[t]{2}{*}{. . } & \multirow[t]{2}{*}{. } & Dakota . & • & 301 & 167 & 75 \\
\hline & & & Wahnatah & • & 344 & 182 & 70 \\
\hline Wabasha . & - . & . & Wabasha. & . & 246 & 84 & 33 \\
\hline \multirow[t]{5}{*}{ Pembina . } & \multirow{5}{*}{\multicolumn{2}{|c|}{. $\cdot$}} & \multirow{5}{*}{\multicolumn{2}{|c|}{$\begin{array}{l}\text { Pembina . } \\
\text { Itasca . . } \\
\text { Mankato . . }\end{array}$}} & 295 & 342 & - \\
\hline & & & & & 21 & 9 & - \\
\hline & & & & & 3253 & \multirow[t]{3}{*}{1687} & \multirow[t]{3}{*}{682} \\
\hline & & & & & 1687 & & \\
\hline & & & & & 4940 & & \\
\hline
\end{tabular}

First census, 1849, August, showing vote for delegate also. 


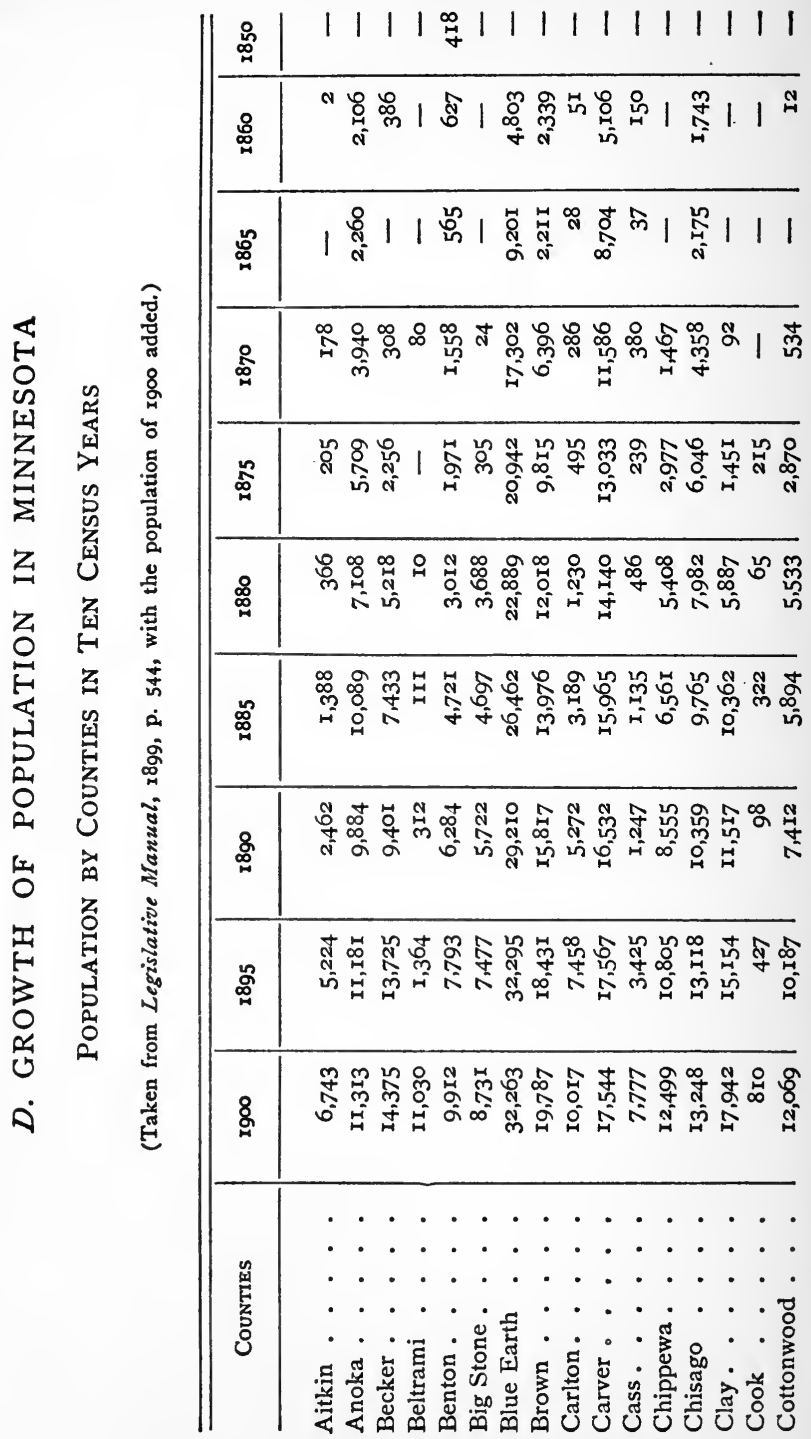




\section{| 㹂 111111111111151111111111111}

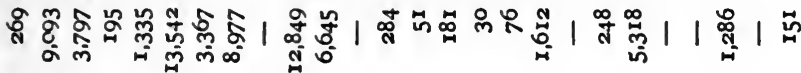

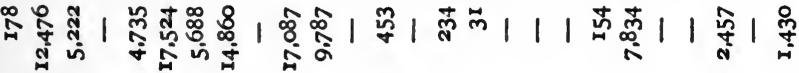

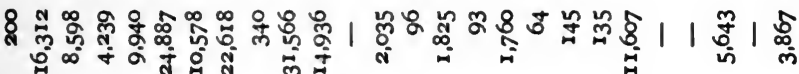

क्ष

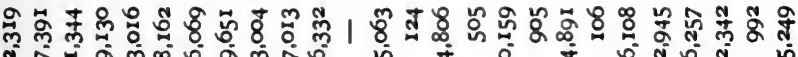
๙

พ \& क⿻

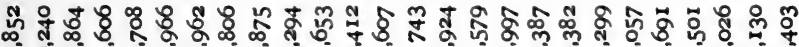

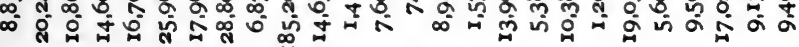

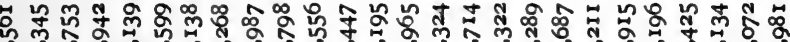

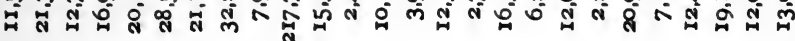

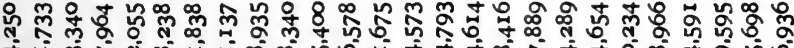
पू

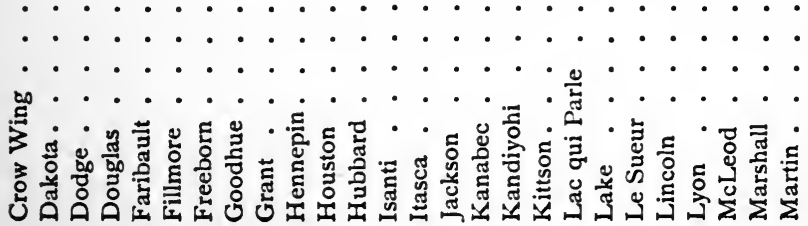




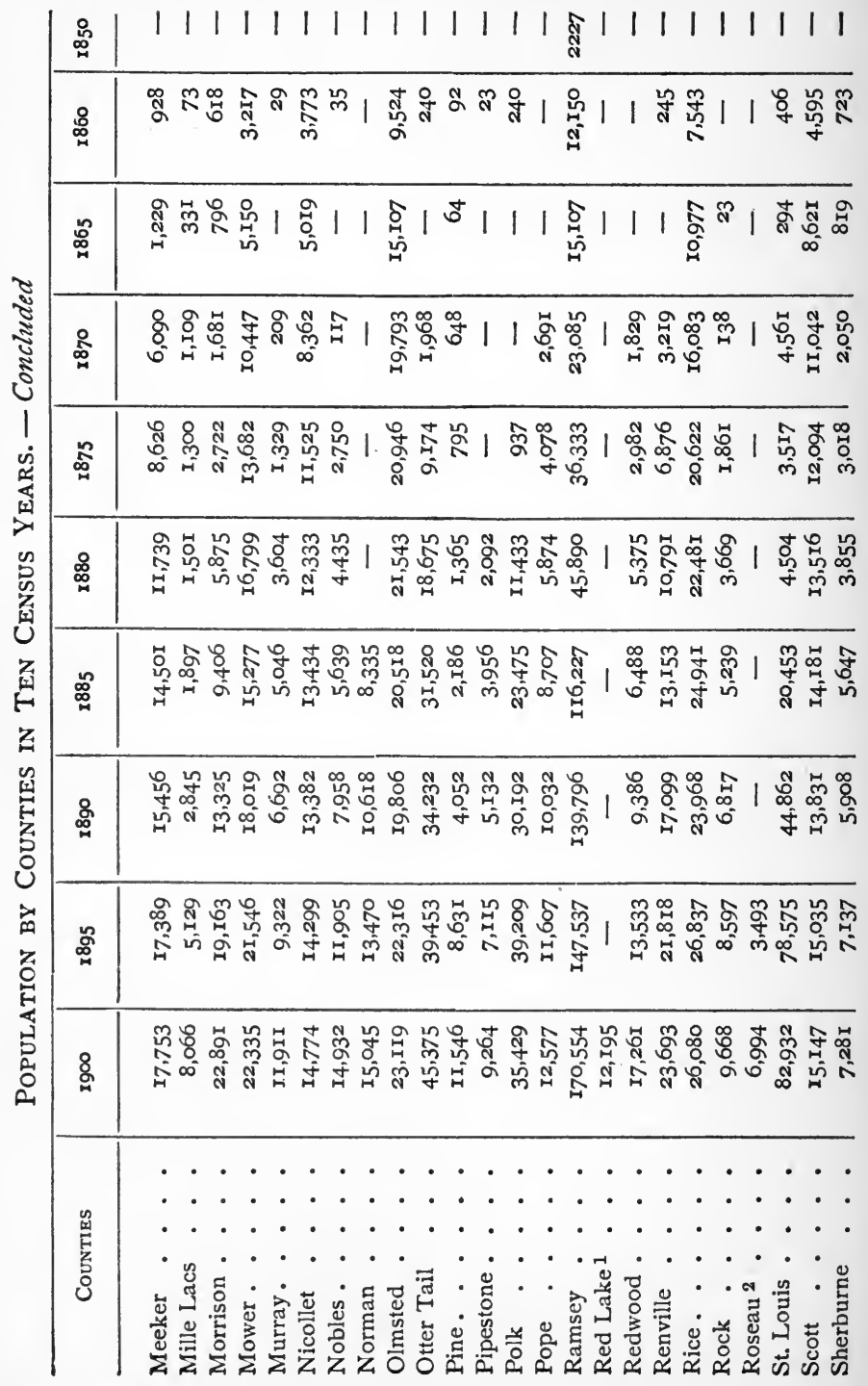


1 1111111 孚

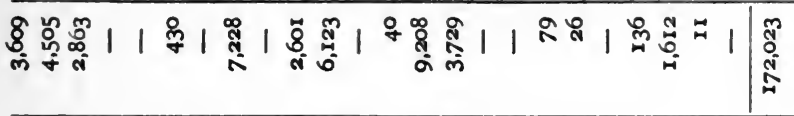

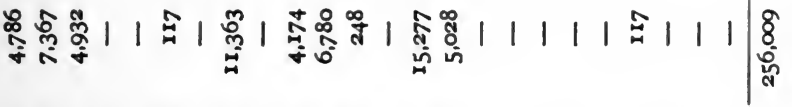

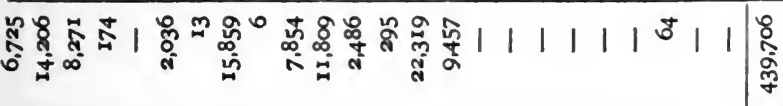

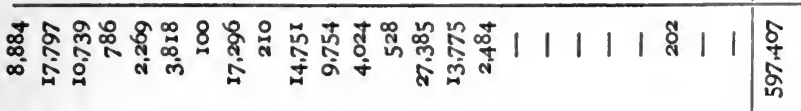

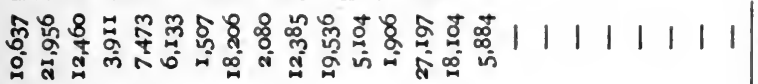

룽

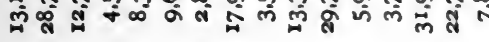

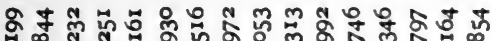
舟

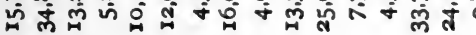

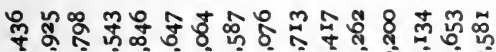

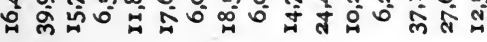

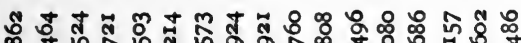

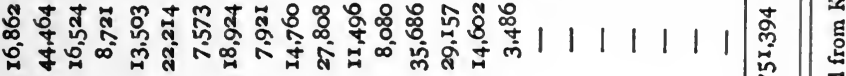

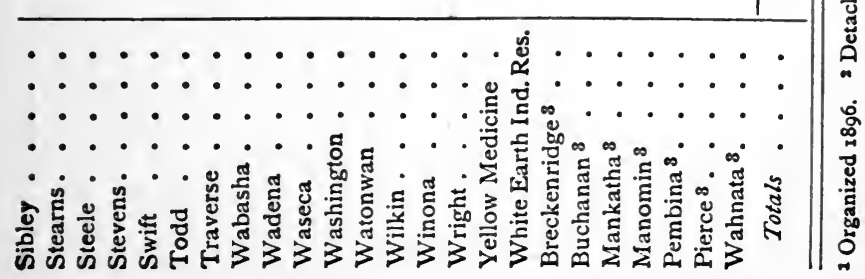




\begin{tabular}{|c|c|}
\hline 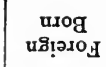 & 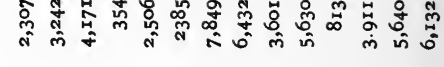 \\
\hline 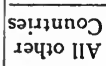 & 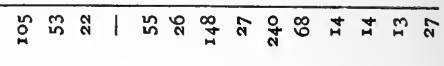 \\
\hline риетәэI & 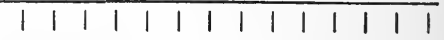 \\
\hline$\overline{\text { pur[u!! }}$ & कmo \\
\hline puriod & 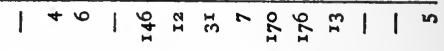 \\
\hline घ!шәч०व & 1 \\
\hline ереü & 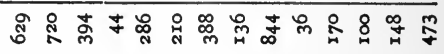 \\
\hline e!ssny & 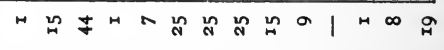 \\
\hline Kemion & 额品递 \\
\hline иәрам & 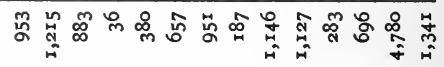 \\
\hline ұнешиа व & m \\
\hline әәиета & "Aa| \\
\hline Киешхәр & 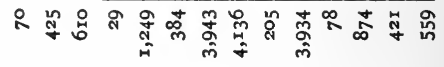 \\
\hline 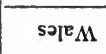 & 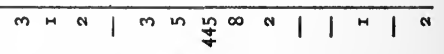 \\
\hline purpors & 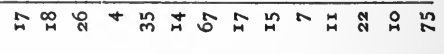 \\
\hline puepial & ల్ల \\
\hline puejồ & 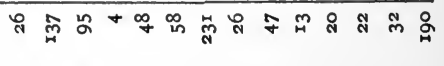 \\
\hline 总号 & 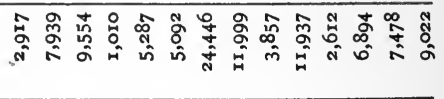 \\
\hline $\begin{array}{l}\text { 苨 } \\
\text { 妾 }\end{array}$ & 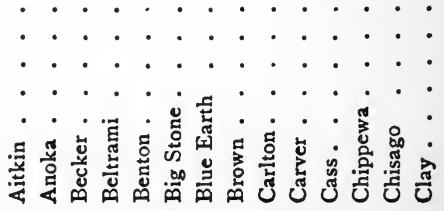 \\
\hline
\end{tabular}




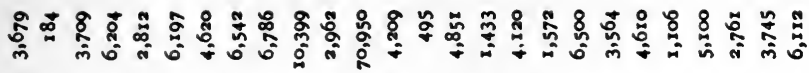

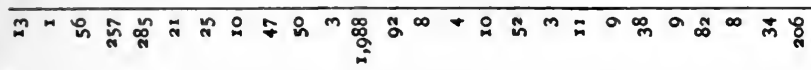

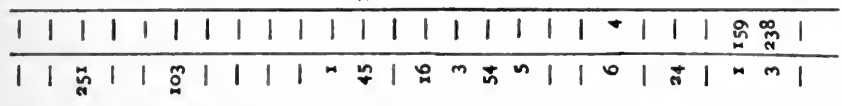

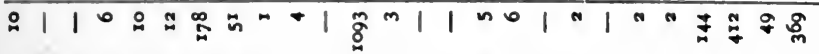

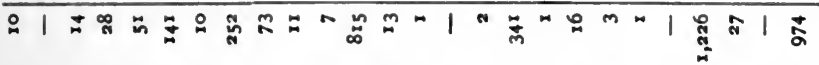

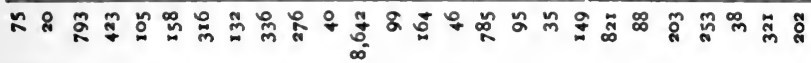

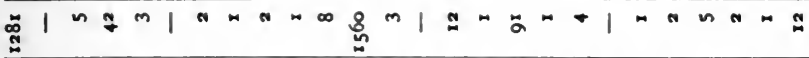

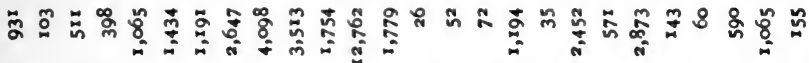

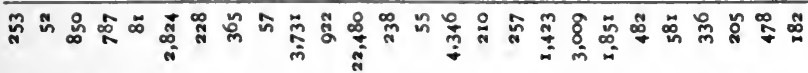

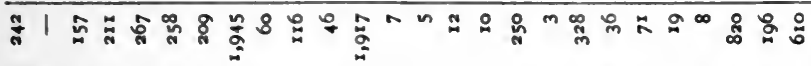
"1 ส

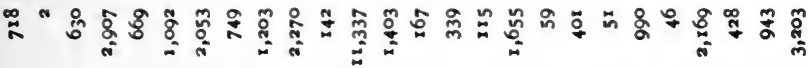

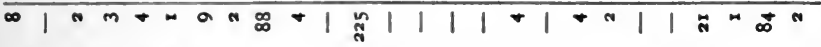

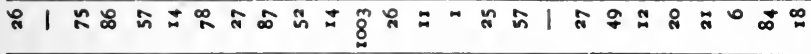

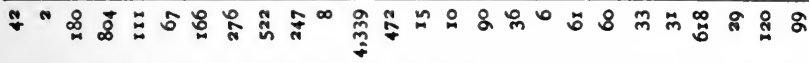

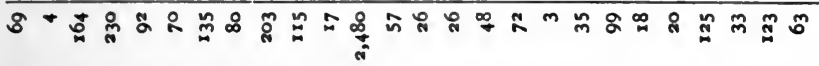

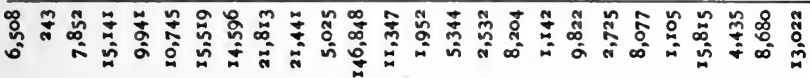

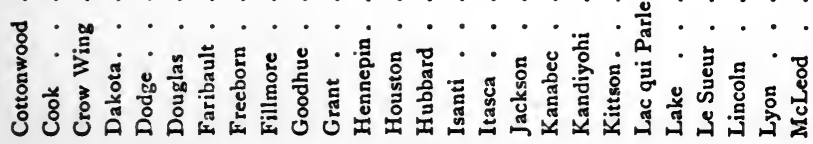




\begin{tabular}{|c|c|}
\hline & 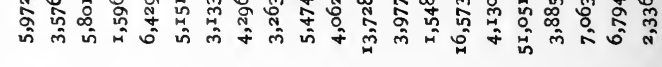 \\
\hline 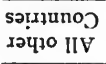 & 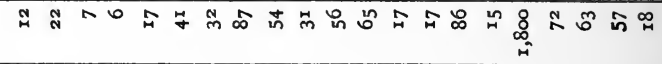 \\
\hline рü[ə⿱亠䒑I & $\begin{array}{llllllllllllllllllllll}1 & 1 & 1 & 1 & 1 & 1 & 1 & 1 & 1 & 1 & 1 & 1 & 1 & 1 & 1 & 1 & 1 & 1 & 1 & 1 & 1\end{array}$ \\
\hline pueju! & 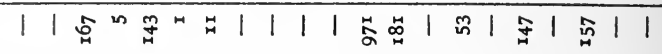 \\
\hline puejod & 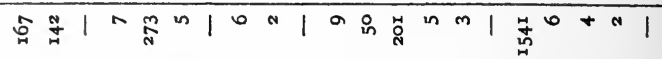 \\
\hline 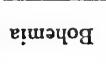 & “ \\
\hline ереиеJ & 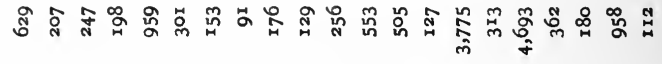 \\
\hline ẹ̣ssny & $+a$ ก ก \\
\hline SeMsoN & 旁 \\
\hline иәра.мS & 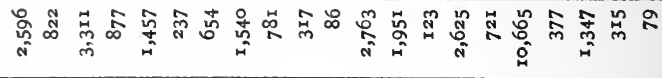 \\
\hline भૃรешนว & 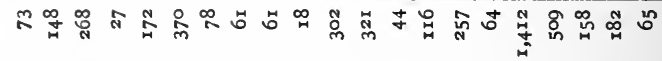 \\
\hline 2ourex & t \\
\hline Кนеแนว & 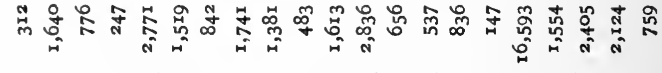 \\
\hline sәге & 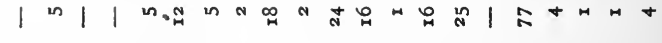 \\
\hline purpoos & 总 \\
\hline риерәдI & 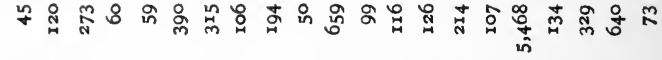 \\
\hline pur [8ి & 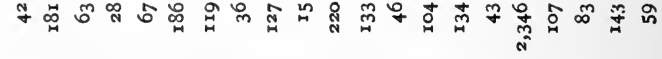 \\
\hline 总 & 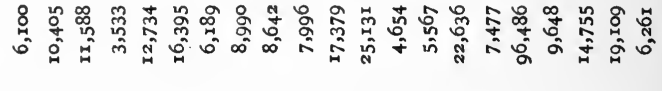 \\
\hline 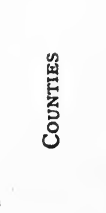 & 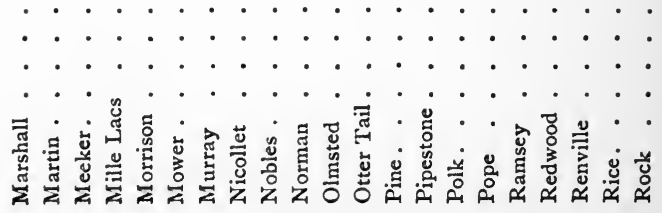 \\
\hline
\end{tabular}




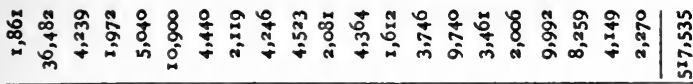

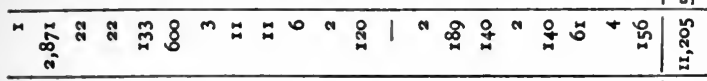

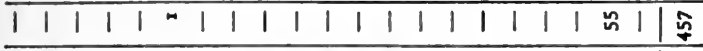

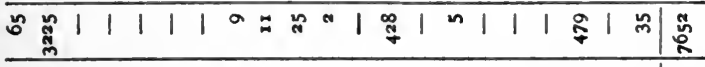

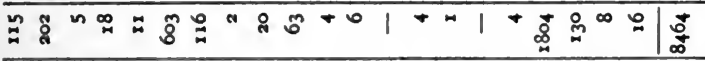

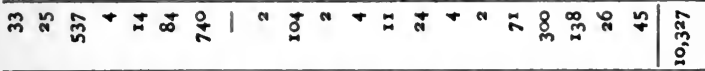

ڤ

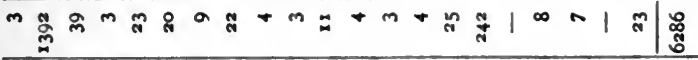

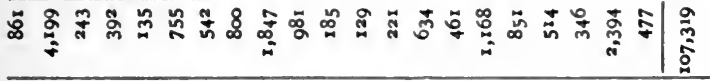

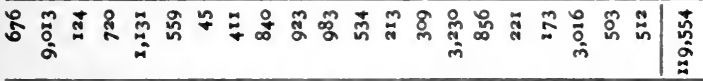

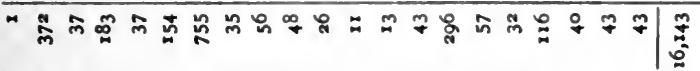

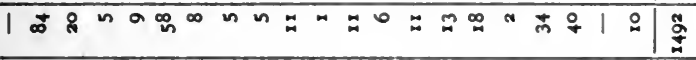

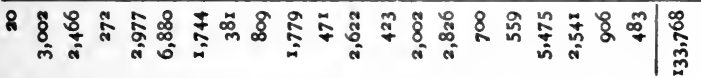

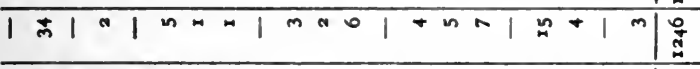

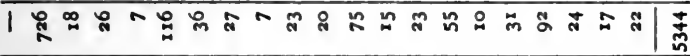

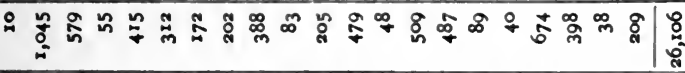

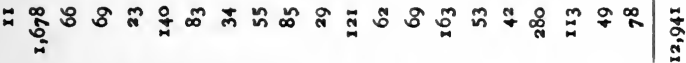

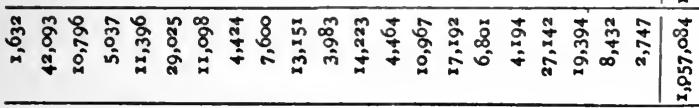




\section{$F$. GROWTH OF CITIES IN MINNESOTA \\ I890-1900}

\begin{tabular}{|c|c|c|c|c|c|c|c|c|}
\hline $\mathrm{Cr}^{\prime}$ & IES & & & & 1900 & I 890 & Increase & Per cent \\
\hline Minneapolis & - & - & • & - & 202,718 & I $64,73^{8}$ & 37,980 & 23.05 \\
\hline St. Paul . & - & - & - & - & 163,632 & 133,156 & 30,476 & 22.8 \\
\hline Duluth . . & - & - & - & • & 52,929 & 33, I I 5 & I9,8I 4 & 59.8 \\
\hline Winona & - & - & - & - & 19,714 & I 8,208 & $\mathrm{I}, 506$ & 8.2 \\
\hline Stillwater . & - & - & - & - & I 2,3 I 8 & I I, 260 & $1,05^{8}$ & 9.04 \\
\hline Mankato . & - & • & • & • & IO,599 & 8,838 & 1,761 & 19.9 \\
\hline St. Cloud . & - & - & • & - & 8,663 & 7,686 & 977 & 12.0 \\
\hline Faribault . & - & - & - & - & 7,868 & 6,520 & 1,348 & 20.6 \\
\hline Red Wing. & - & - & - & $\cdot$ & 7,525 & 6,294 & 1,231 & 19.6 \\
\hline Brainerd . & - & . & · & $\cdot$ & $7,5^{24}$ & 5,703 & I,80I & 31.9 \\
\hline Rochester. & - & - & $\cdot$ & $\cdot$ & 6,843 & 5,321 & 1,522 & 28.6 \\
\hline Fergus Falls & - & - & $\cdot$ & $\cdot$ & 6,072 & 3,772 & 2,300 & 60.9 \\
\hline Little Falls & - & . & $\cdot$ & $\cdot$ & 5,774 & 2,354 & 3,420 & 104.5 \\
\hline Owatonna. & - & - & $\cdot$ & - & 5,561 & 3,849 & 1,712 & $44 \cdot 4$ \\
\hline Austin . . & - & - & $\cdot$ & $\cdot$ & 5,474 & 3,901 & 1,573 & 40.3 \\
\hline New Ulm. & • & - & $\cdot$ & $\cdot$ & $5,4 \circ 3$ & $3,74 \mathbf{I}$ & $\mathbf{I}, 662$ & $44 \cdot 4$ \\
\hline Crookston . & - & . & - & - & 5,359 & 3,457 & 1,902 & 55.0 \\
\hline Albert Lea & - & . & $\cdot$ & $\cdot$ & 4,500 & 3,305 & I, I95 & 36.1 \\
\hline St. Peter . & - & - & • & . & 4,302 & 3,67 I & 631 & $17 \cdot 1$ \\
\hline Hastings . & - & - & $\cdot$ & - & $3,8 \mathrm{II}$ & 3,705 & 106 & 2.9 \\
\hline Anoka . & - & - & $\cdot$ & $\cdot$ & 3,769 & 4,252 & -483 & ${ }^{1}$ II. 3 \\
\hline Moorhead. & - & . & $\cdot$ & • & $3,73^{\circ}$ & 2,088 & 1,642 & 78.6 \\
\hline Ely . . . & - & - & $\cdot$ & - & 3,712 & 901 & 2,8 I I & 311.9 \\
\hline Willmar . & - & . & $\cdot$ & • & 3,409 & I,825 & 1,584 & 86.7 \\
\hline Two Harbor & s. & - & $\cdot$ & - & 3,278 & - & - & - \\
\hline Northfield . & - & - & $\cdot$ & • & 3,210 & 2,659 & $55^{I}$ & 20.7 \\
\hline Waseca. . & - & - & • & - & 3,103 & 2,482 & 621 & 20.5 \\
\hline Cloquet. . & - & - & - & - & 3,074 & 2,530 & 544 & 21.5 \\
\hline Fairmont . & - & - & $\cdot$ & - & 3,040 & $\mathrm{I}, 205$ & 1,835 & 105.2 \\
\hline Virginia . & & • & - & - & 2,962 & - & - & - \\
\hline Blue Earth & City & - & · & - & 2,900 & 1,569 & $\mathbf{I}, 331$ & 84.8 \\
\hline
\end{tabular}




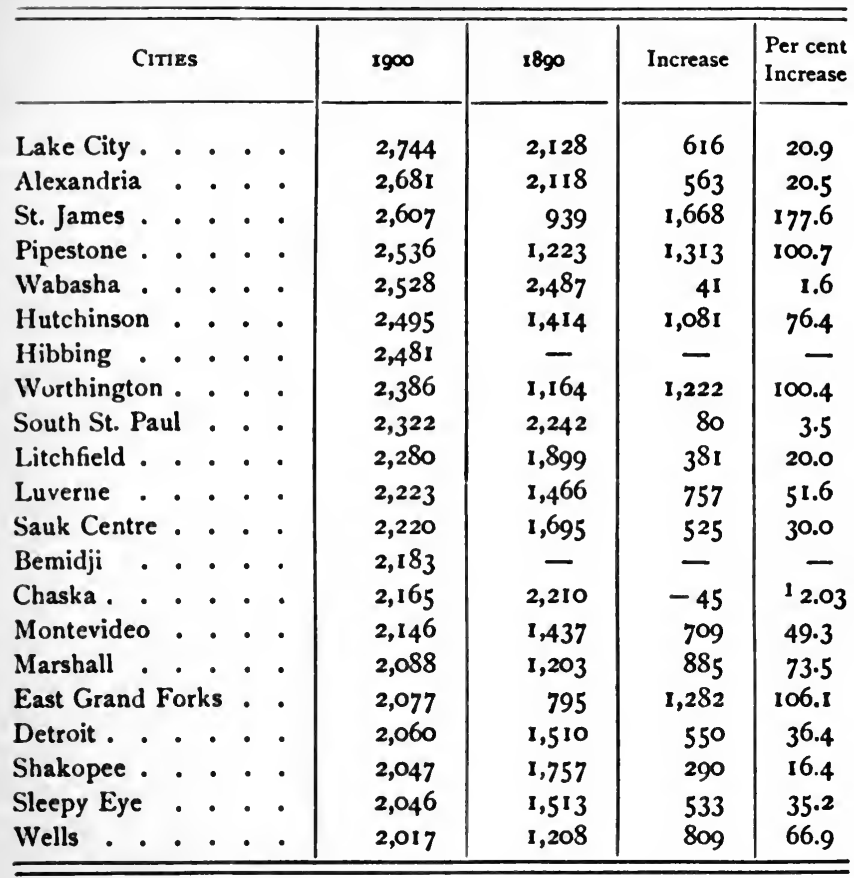

1 Loss. 


\section{G. AN ACT TO ESTABLISH THE TERRITORIAL GOVERNMENT OF MINNESOTA}

[Passed March 3, 1849]

Section I. Be it enacted by the Senate and House of Representatives of the United States of America in Congress assembled, That from and after the passage of this act, all that part of the territory of the United States which lies within the following limits, to wit: Beginning in the Mississippi river, at the point where the line of forty-three degrees and thirty minutes of north latitude crosses the same; thence running due west on said line, which is the northern boundary of the State of Iowa, to the northwest corner of the said State of Iowa; thence southerly along the western boundary of said state to the point where said boundary strikes the Missouri river; thence up the middle of the main channel of the Missouri river to the mouth of White Earth river; thence up the middle of the main channel of the White Earth river to the boundary line between the possessions of the United States and Great Britain; thence east and south of east along the boundary line between the possessions of the United States and Great Britain to Lake Superior; thence in a straight line to the northernmost point of the State of Wisconsin in Lake Superior; thence along the western boundary line of said State of Wisconsin to the Mississippi river; thence down the main channel of said river to the place of beginning, be and the same is hereby erected into a temporary government by the name of the Territory of Minnesota; provided, that nothing in this act contained shall be construed to inhibit the government of the United States from dividing said territory into two or more territories, in such manner and at such times as Congress shall deem convenient and proper, or from attaching any portion of said Territory to any other State or territory of the United States.

SEC. 2. And be it further enacted, That the executive power and authority in and over said Territory of Minnesota shall be 
vested in a governor, who shall hold his office for four years, and until his successor shall be appointed and qualified, unless sooner removed by the president of the United States. The governor shall reside within said Territory; shall be commander-in-chief of the militia thereof; shall perform the duties and receive the emoluments of superintendent of Indian affairs. He may grant pardons for offences against the laws of said Territory, and reprieves for offences against the laws of the United States until the decision of the president can be made known thereon; he shall commission all officers who shall be appointed to office under the laws of the said Territory, and shall take care that the laws be faithfully executed.

SEC. 3. And be it further enacted, That there shall be a secretary of said Territory, who shall reside therein, and hold his office for four years, unless sooner removed by the president of the United States; he shall record and preserve all the laws and proceedings of the legislative assembly hereinafter constituted, and all the acts and proceedings of the governor in his executive department; he shall transmit one copy of the laws and one copy of the executive proceedings, on or before the first day of December in each year, to the president of the United States, and at the same time two copies of the laws to the speaker of the house of representatives, and the president of the senate, for the use of Congress. And in case of the death, removal, resignation, or necessary absence of the governor from the Territory, the secretary shall be and he is hereby authorized and required to execute and perform all the powers and the duties of the governor during such vacancy or necessary absence, or until another governor shall be duly appointed to fill such vacancy.

SEC. 4. And be it further enacted, That the legislative power and authority of said Territory shall be vested in the governor and a legislative assembly. The legislative assembly shall consist of a council and house of representatives. The council shall consist of nine members having the qualifications of voters, as hereinafter prescribed, whose term of service shall continue two years. The house of representatives shall, at its first session, consist of eighteen members, possessing the same qualifications as prescribed for members of the council, and whose term of service shall continue one year. The number of councillors and 
representatives may be increased by the legislative assembly, from time to time, in proportion to the increase of population; provided, that the whole number shall never exceed fifteen councillors and thirty-nine representatives. An apportionment shall be made, as nearly equal as practicable, among the several counties or districts for the election of the council and representatives, giving to each section of the Territory representation in the ratio of its population, Indians excepted, as nearly as may be. And the members of the council and of the house of representatives shall reside in and be inhabitants of the districts for which they may be elected, respectively. Previous to the first election, the governor shall cause a census or enumeration of the inhabitants of the several counties and districts of the Territory to be taken, and the first election shall be held at such time and places and be conducted in such manner as the governor shall appoint and direct; and he shall, at the same time, declare the number of members of the council and house of representatives to which each of the counties and districts shall be entitled under this act.

The number of persons authorized to be elected having the highest number of votes, in each of said council districts for members of the council, shall be declared by the governor to be duly elected to the council, and the person or persons authorized to be elected, having the greatest number of votes for the house of representatives, equal to the number to which each county or district shall be entitled, shall also be declared by the governor to be duly elected members of the house of representatives; provided, that in case of a tie between two or more persons voted for, the governor shall order a new election to supply the vacancy made by such tie. And the persons thus elected to the legislative assembly shall meet at such place on such day as the governor shall appoint, but thereafter the time, place, and manner of holding and conducting all elections by the people, and the apportioning of the representation in the several counties or districts to the council and house of representatives, according to the population, shall be prescribed by law, as well as the day of the commencement of the regular session of the legislative assembly; provided, that no one session shall exceed the term of sixty days. 
SEC. 5. And be it further enacted, That every free white male inhabitant above the age of twenty-one years, who shall have been a resident of said Territory at the time of the passage of this act, shall be entitled to vote at the first election, and shall be eligible to any office within the said Territory; but the qualifications of voters and of holding office at all subsequent elections shall be such as shall be prescribed by the legislative assembly; provided, that the right of suffrage and of holding office shall be exercised only by citizens of the United States and those who shall have declared on oath their intention to become such, and shall have taken an oath to support the Constitution of the United States and the provisions of this act.

SEC. 6. And be it further enacted, That the legislative power of the Territory shall extend to all rightful subjects of legislation, consistent with the Constitution of the United States and the provisions of this act; but no law shall be passed interfering with the primary disposal of the soil; no tax shall be imposed upon the property of the United States; nor shall the lands or other property of non-residents be taxed higher than the lands or other property of residents. All the laws passed by the legislative assembly and governor shall be submitted to the Congress of the United States, and if disapproved shall be null and void and of no effect.

SEC. 7. And be it further enacted, That all township, district, and county officers, not herein otherwise provided for, shall be appointed or elected, as the case may be, in such manner as shall be provided by the governor and legislative assembly of the Territory of Minnesota. The governor shall nominate and, by and with the advice and consent of the legislative council, appoint all officers not herein otherwise provided for, and, in the first instance, the governor alone may appoint all said officers, who shall hold their offices until the end of the next session of the legislative assembly.

SEc. 8. And be it further enacted, That no member of the legislative assembly shall hold or be appointed to any office which shall have been created, or the salary or emoluments of which shall have been increased, while he was a member, during the term for which he was elected, and for one year after the expiration of such term; and no person holding a commission or appointment 
under the United States, except postmasters, shall be a member of the legislative assembly, or shall hold any office under the government of said Territory.

SEc. 9. And be it further enacted, That the judicial power of said Territory shall be vested in a supreme court, district courts, probate courts, and in justices of the peace. The supreme court shall consist of a chief justice and two associate justices, any two of whom shall constitute a quorum, and who shall hold a term at the seat of government of said Territory annually; and they shall hold their offices during the period of four years. The said Territory shall be divided into three judicial districts, and a district court shall be held in each of said districts by one of the justices of the supreme court, at such time and places as may be prescribed by law; and the said judges shall, after their appointment, respectively, reside in the districts which shall be assigned them. The jurisdiction of the several courts herein provided for, both appellate and original, and that of probate courts and justices of the peace, shall be as limited by law; provided, that the justices of the peace shall not have jurisdiction of any matter in controversy when the title or boundaries of land may be in dispute, or where the debt or sum claimed shall exceed one hundred dollars; and the said supreme and district courts, respectively, shall possess chancery as well as common law jurisdiction. Each district court, or the judges thereof, shall appoint its clerk, who shall also be the register in chancery, and shall keep his office at the place where the court may be held. Writs of error, bills of exception, and appeals shall be allowed in all cases from the final decisions of said district courts to the supreme court, under such regulations as may be prescribed by law, but in no case removed to the supreme court shall trial by jury be allowed in said court. The supreme court, or the justices thereof, shall appoint its own clerk, and every clerk shall hold his office at the pleasure of the court for which he shall have been appointed. Writs of error and appeals from the final decisions of said supreme court shall be allowed, and may be taken to the supreme court of the United States, in the same manner and under the same regulations as from the circuit courts of the United States, where the value of the property or the amount in controversy, to be ascertained by the oath or affirmation of either party, or other competent witness, 
shall exceed one thousand dollars; and each of the said district courts shall have and exercise the same jurisdiction in all cases arising under the Constitution and laws of the United States, as is vested in the circuit and district courts of the United States; and the first six days of every term of said courts, or so much thereof as shall be necessary, shat be appropriated to the trial of causes arising under the said Constitution and laws; and writs of error and appeal in all such cases shall be made to the supreme court of said Territory, the same as in other cases. The said clerk shall receive in all such cases the same fees which the clerks of the district courts of the late Wisconsin Territory received for similar services.

SEc. 10. And be it further enacted, That there shall be appointed an attorney for said Territory, who shall continue in office for four years, unless sooner removed by the president, and who shall receive the same fees and salary as the attorney of the United States for the late Territory of Wisconsin received. There shall also be a marshal for the Territory appointed, who shall hold his office for four years, unless sooner removed by the president, and who shall exccute all processes issuing from the said courts, when exercising their jurisdiction as circuit and district courts of the United States; he shall perform the duties, be subject to the same regulaticns and penalties, and be entitled to the same fees as the marshal of the district court of the United States for the late Territory of Wisconsin; and shall, in addition, be paid two hundred dollars annually as a compensation for extra services.

SEC. I1. And be it further enacted, That the governor, secretary, chief justice and associate justices, attorney and marshal, shall be nominated and, by and with the advice and consent of the senate, appointed by the president of the United States. The governor and secretary to be appointed as aforesaid, shall, before they act as such, respectively, take an oath or affirmation, before the district judge, or some justice of the peace in the limits of said Territory, duly authorized to administer oaths and affirmations by the laws now in force therein, or before the chief justice, or some associate justice of the supreme court of the United States, to support the Constitution of the United States, and faithfully to discharge the duties of their respective offices, which 
said oaths, when so taken, shall be certified by the person by whom the same shall have been taken, and such certificates shall be received and recorded by the said secretary among the executive proceedings; and the chief justice and associate justices, and all other civil officers in said Territory, before they act as such, shall take a like oath or affirmation, before the said governor or secretary, or some judge or justice of the peace of the Territory, who may be duly commissioned and qualified; which said oath or affirmation shall be certified and transmitted, by the person taking the same, to the secretary, to be by him recorded as aforesaid; and afterwards, the like oath or affirmation shall be taken, certified and recorded in such manner and form as may be prescribed by law. The governor shall receive an annual salary of $\$ I, 500$ as governor, and $\$ I, 000$ as superintendent of Indian affairs. The chief justice and associate justice shall each receive an annual salary of $\$ 1,800$. The secretary shall receive an annual salary of $\$ I, 800$. The said salaries shall be paid quarter-yearly, at the treasury of the United States. The members of the legislative assembly shall be entitled to receive three dollars each per day during their attendance at the sessions thereof, and three dollars each for every twenty miles traveled in going to and returning from the said sessions, estimated according to the nearest usually travelled route. There shall be appropriated, annually, the sum of $\$ 1,000$, to be expended by the governor to defray the contingent expenses of the Territory: and there shall also be appropriated, annually, a sufficient sum to be expended by the secretary of the Territory, and upon an estimate to be made by the secretary of the treasury of the United States, to defray the expenses of the legislative assembly, the printing of the laws, and other incidental expenses, and the secretary of the Territory shall annually account to the secretary of the treasury of the United States for the manner in which the aforesaid sum shall have been expended.

SEC. 12. And be it further enacted, That the inhabitants of the said Territory shall be entitled to all the rights, privileges, and immunities heretofore granted and secured to the Territory of Wisconsin and to its inhabitants; and the laws in force in the Territory of Wisconsin at the date of the admission of the State of Wisconsin shall continue to be valid and operative therein, so far as the same be not incompatible with the provisions of this 
act. subject, nevertheless, to be altered, modified, or repealed by the governor and legislative assembly of the said Territory of Minnesota; and the laws of the United States are hereby extended over, and declared to be in force in said Territory, so far as the same, or any provision thereof, may be applicable.

SEC. 13. And be it further enacted, That the legislative assembly of the Territory of Minnesota shall hold its first session in St. Paul; and at said first session the governor and legislative assembly shall locate and establish a temporary seat of government for said Territory, at such place as they may deem eligible; and shall at such time as they shall see proper prescribe by law the manner of locating the permanent seat of government of said Territory by a vote of the people. And the sum of twenty thousand dollars, out of any money in the treasury not otherwise appropriated, is hereby appropriated and granted to said Territory of Minnesota, to be applied by the governor and legislative assembly to the erection of suitable public buildings at the seat of government.

SEc. 14. And be it further cnacted, That a delegate to the house of representatives of the United States, to serve for the term of two years, may be elected by the voters qualified to elect members of the legislative assembly, who shall be entitled to the same rights and privileges as are exercised and enjoyed by the delegates from the several other territories of the United States to the said house of representatives. The first election shall be held at such times and places and be conducted in such manner as the governor shall appoint and direct; and at all subsequent elections the times, places, and manner of holding the elections shall be prescribed by law. The person having the greatest number of votes shall be declared by the governor to be duly elected, and a certificate thereof shall be given accordingly.

SEc. 15. And be it further enacted, That all suits, process, and proceedings, civil and criminal, at law or in chancery, and all indictments and informations, which shall be pending and undetermined in the courts of the Territory of Wisconsin, within the limits of said Territory of Minnesota, when this act shall take effect, shall be transferred to be heard, tried, prosecuted, and determined in the district courts hereby established, which may include the counties or districts where any such proceeding may be 
pending. All bonds, recognizances, and obligations of every kind whatsoever, valid under the existing laws, within the limits of said Territory, shall be valid under this act ; and all crimes and misdemeanors against the laws, in force within said limits, may be prosecuted, tried, and punished in the courts established by this act; and all penalties, forfeitures, actions, and causes of action may be recovered under this act the same as they would have been under the laws in force within the limits composing said Territory at the time this act shall go into operation.

SEC. I6. And be it further enacted, That all justices of the peace, constables, sheriffs, and all other judicial and ministerial officers, who shall be in office within the limits of said Territory when this act shall take effect, shall be and they are hereby authorized and required to continue to exercise and perform the duties of their respective offices as officers of the Territory of Minnesota, temporarily, and until they or others shall be duly appointed and qualified to fill their places, in the manner herein directed, or until their offices shall be abolished.

SEC. 17. And be it further enacted, That the sum of $\$ 5,000$ be and the same is hereby appropriated out of any moneys in the treasury not otherwise appropriated, to be expended by and under the direction of the said governor of the Territory of Minnesota, in the purchase of a library, to be kept at the seat of government for the use of the governor, legislative assembly, judges of the supreme court, secretary, marshal, and attorneys of said Territory, and such other persons and under such regulations as shall be prescribed by law.

SEC. 18. And be it further enacted, That when the lands in said Territory shall be surveyed under the direction of the government of the United States, preparatory to bringing the same into market, sections numbered sixteen and thirty-six in each township in said Territory shall be and the same are hereby reserved for the purpose of being applied to schools in said Territory, and in the State and Territories hereafter to be erected out of the same.

SEC. 19. And be it further enacted, That temporarily, and until otherwise provided by law, the governor of said Territory may define the judicial districts of said Territory, and assign the judges who may be appointed for said Territory to the several districts, and also appoint the times and places for holding courts 
in the several counties or subdivisions in each of said judicial districts, by proclamation to be issued by him ; but the legislative assembly, at their first or any subsequent session, may organize, alter, or modify such judicial districts, and assign the judges, and alter the times and places of holding the courts, as to them shall seem proper and convenient.

SEC. 20. And be it further enacted, That every bill which shall or may pass the council and house of representatives, shall, before it becomes a law, be presented to the governor of the Territory; if he approve, he shall sign it ; but if not, he shall return it, with his objections, to the house in which it originated; which shall cause the objections to be entered at large upon their journal, and proceed to reconsider it. If, after such reconsideration, twothirds of that house shall agree to pass the bill, it shall be sent, together with the objections, to the other house, by which it shall also be reconsidered, and if approved by two-thirds of that house it shall become a law; but in all such cases the votes of both houses shall be determined by yeas and nays, and the names of the persons voting for or against the bill shall be entered on the journal of each house, respectively. If any bill shall not be returned by the governor within three days (Sundays excepted) after it shall have been presented to him, the same shall be a law in like manner as if he had signed it, unless the legislative assembly, by adjournment, prevent it ; in which case it shall not become a law. 


\title{
$H$. THE ENABLING ACT OF MINNESOTA ${ }^{1}$
}

\author{
[Passed Feb. 26, 1857]
}

Section 1. Be it enacted by the Senate and House of Representatives of the United States of America, in Congress assembled, That the inhabitants of that portion of the Territory of Minnesota which is embraced within the following limits, to-wit: Beginning at the point in the centre of the main channel of the Red River of the North, where the boundary line between the United States and the British Possessions crosses the same; thence up the main channel of said river to that of the Bois de Sioux river; thence up the main channel of said river to Lake Traverse; thence up the centre of said lake to the southern extremity thereof; thence in a direct line to the head of Big Stone lake; thence through its centre to its outlet; thence by a due south line to the north of the State of Iowa; thence along the northern boundary of said State to the main channel of the Mississippi river; thence up the main channel of said river, and following the boundary line of the State of Wisconsin, until the same intersects with the St. Louis river; thence down the said river to and through Lake Superior, on the boundary line of Wisconsin and Michigan, until it intersects the dividing line between the United States and the British Possessions; thence up Pigeon river and following said dividing line to the place of beginning, be and they hereby are authorized to form for themselves a constitution and State government by the name of the State of Minnesota, and to come into the Union on an equal footing with the original States, according to the Federal Constitution.

SEC. 2. And be it further enacted, That the State of Minnesota shall have concurrent jurisdiction on the Mississippi and all other rivers and waters bordering on the said State of Minnesota, so far as the same shall form a common boundary to said State and any State or States now or hereafter to be formed or bounded by

1 One of the first steps in the admission of a new State to the Union is the enactment by Congress of an act authorizing the people of the Territory to form a State government. Such an act is technically known as an enabling act. 
the same; and said river or waters leading into the same shall be common highways, and forever free, as well to the inhabitants of said State as to all other citizens of the United States, without any tax, duty, impost, or toll therefor.

SEC. 3. And be it further enacted, That on the first Monday in June next, the legal voters in each representative district then existing within the limits of the proposed State, are hereby authorized to elect two delegates for each representative to which said district shall be entitled according to the apportionment for representatives to the Territorial legislature; which election for delegates shall be held and conducted, and the returns made, in all respects in conformity with the laws of said Territory regulating the election of representatives, and the delegates so elected shall assemble at the capital of said Territory on the second Monday in June next, and first determine by a vote whether it is the wish of the people of the proposed State to be admitted into the Union at that time; and if so, shall proceed to form a constitution, and take all necessary steps for the establishment of a State government, in conformity with the Federal Constitution, subject to the approval and ratification of the people of the proposed State.

SEC. 4. And be it further enacted, That in the event said convention shall decide in favor of the immediate admission of the proposed State into the Union, it shall be the duty of the United States marshal for said Territory to proceed to take a census or enumeration of the inhabitants within the limits of the proposed State, under such rules and regulations as shall be prescribed by the secretary of the interior, with the view of ascertaining the number of representatives to which said State may be entitled in the Congress of the United States. And said State shall be entitled to one representative, and such additional representatives as the population of the State shall, according to the census, show it would be entitled to according to the present ratio of representation.

SEC. 5. And be it further enacted, That the following propositions be and the same are hereby offered to the said convention of the people of Minnesota for their free acceptance or rejection, which, if accepted by the convention, shall be obligatory on the United States, and upon the said State of Minnesota, to-wit: 
First - That sections numbered sixteen and thirty-six in every township of public lands in said State, and where either of said sections, or any part thereof, has been sold or otherwise disposed of, other lands, equivalent thereto, and as contiguous as may be, shall be granted to said State for the use of schools.

Second - That seventy-two sections of land shall be set apart and reserved for the use and support of a State university, to be selected by the governor of said State, subject to the approval of the commissioner at the general land office, and to be appropriated and applied in such manner as the legislature of said State may prescribe, for the purpose aforesaid, but for no other purpose.

Third - Ten entire sections of land to be selected by the governor of said State, in legal subdivisions, shall be granted to said State for the purpose of completing the public buildings, or for the erection of others at the seat of government, under the direction of the legislature thereof.

Fourth - That all salt springs within said State, not exceeding twelve in number, with six sections of land adjoining or as contiguous as may be to each, shall be granted to said State for its use; and the same to be selected by the governor thereof within one year after the admission of said State, and, when so selected, to be used or disposed of on such terms, conditions, and regulations as the legislature shall direct; provided, that no salt spring or land the right whereof is now vested in any individual or in individuals, or which may be hereafter confirmed or adjudged to any individual or individuals, shall by this article be granted to said State.

Fifth - That five per centum of the net proceeds of sales of all public lands lying within said State, which shall be sold by Congress after the admission of said State into the Union, after deducting all the expenses incident to the same, shall be paid to said State for the purpose of making public roads and internal improvements as the legislature shall direct; provided, the foregoing propositions herein offered are on the condition that the said convention which shall form the constitution of said State shall provide, by a clause in said constitution, or an ordinance, irrevocable without the consent of the United States, that said State shall never interfere with the primary disposal of the soil 
within the same by the United States, or with any regulations Congress may find necessary for securing the title in said soil in bona fide purchasers thereof; and that no tax shall be imposed on lands belonging to the United States, and that in no case shall non-resident proprietors be taxed higher than residents. 


\section{AN ACT FOR THE ADMISSION OF MINNESOTA INTO THE UNION}

[Passed May IT, 1858]

Whereas, an act of Congress was passed February twentysixth, eighteen hundred and fifty-seven, entitled "An act to authorize the people of the Territory of Minnesota to form a constitution and State government preparatory to their admission into the Union on an equal footing with the original States;" and, whereas, the people of said Territory did, on the twentyninth day of August, eighteen hundred and fifty-seven, by delegates elected for that purpose, form for themselves a constitution and State government, which is republican in form, and was ratified and adopted by the people at an election held on the thirteenth day of October, eighteen hundred and fifty-seven, for that purpose; therefore,

Be it enacted by the Senate and House of Representatives of the United States of America, in Congress assembled, That the State of Minnesota shall be one, and is hereby declared to be one, of the United States of America, and admitted into the Union on an equal footing with the original States in all respects whatever.

SEC. 2. And be it further enacted, That said State shall be entitled to two representatives in Congress, until the next apportionment of representatives among the several States.

SEC. 3. And be it further enacted, That from and after the admission of the State of Minnesota, as hereinbefore provided, all the laws of the United States which are not locally inapplicable shall have the same force and effect within that State as in other States of the Union; and the said State is hereby constituted a judicial district of the United States; within which a district court, with like powers and jurisdiction as the district court of the United States for the district of Iowa, shall be established; the judge, attorney, and marshal of the United States of the said district of Minnesota shall reside within the same, and shall be entitled to the same compensation as the judge, attorney, and 
marshal of the district of Iowa; and in all cases of appeal or writ of error heretofore prosecuted and now pending in the supreme court of the United States, upon any record from the supreme court of Minnesota Territory, the mandate of execution or order of further proceedings shall be directed by the supreme court of the United States to the district court of the United States for the district of Minnesota, or to the supreme court of the State of Minnesota, as the nature of such appeal or writ of error may require; and each of those courts shall be the successor of the supreme court of Minnesota Territory, as to all such cases, with full power to hear and determine the same, and to award mesne or final process therein. 


\title{
$J$. CONStitution of the StATE OF Minnesota
}

\author{
Adopted October 13, 1857. Ayes, 30,055; Noes, 571 .
}

Preamble. Preamble. We, the people of the State of Minnesota, grateful to God for our civil and religious liberty, and desiring to perpetuate its blessings and secure the same to ourselves and our posterity, do ordain and establish this constitution:

\section{ARTICle I}

\section{Bill of Rights}

Object of government.

Rights and privileges.

Liberty of the press.

Right of trial by jury.

No excessive bail or unusual punishments.
SECTION I. Government is instituted for the security, benefit and protection of the people, in whom all political power is inherent, together with the right to alter, modify, or reform such government, whenever the public good may require it.

SEc. 2. No member of this State shall be disfranchised, or deprived of any of the rights or privileges secured to any citizen thereof, unless by the law of the land, or the judgment of his peers. There shall be neither slavery nor involuntary servitude in the State otherwise than in the punishment of crime, whereof the party shall have been duly convicted.

SEC. 3. The liberty of the press shall forever remain inviolate, and all persons may freely speak, write, and publish their sentiments on all subjects, being responsible for the abuse of such right. SEC. 4. The right of trial by jury shall remain inviolate, and shall extend to all cases at law without regard to the amount in controversy, but a jury trial may be waived by the parties in all cases in the manner prescribed by law; [and the legislature may provide that the agreement of five-sixths of any jury in any civil action or proceeding, after not less than six (6) hours' deliberation, shall be sufficient verdict therein.] ${ }^{1}$

SEC. 5. Excessive bail shall not be required, nor shail excessive fines be imposed; nor shall cruel or unusual punishments be inflicted. 
SEc. 6. In all criminal prosecutions the accused shall enjoy the right to a speedy and public trial, by an impartial jury of the county or district wherein the crime shall have been committed, which county or district shall have been previously ascertained by law, and to be informed of the nature and cause of the accusation, to be confronted with the witnesses against him, to have compulsory process for obtaining witnesses in his favor, and to have the assistance of counsel in his defence. ${ }^{1}$

SEC. 7. No person shall be held to answer for a criminal offence unless on the presentment or indictment of a grand jury, except in cases of impeachment, or in cases cognizable by justices of the peace, or arising in the army or navy, or in the militia when in actual service in time of war or public danger; and no person for the same offence shall be put twice in jeopardy of punishment, nor shall be compelled in any criminal case to be witness against himself, nor be deprived of life, liberty, or property without due process of law. All persons shall, before conviction, be bailable by sufficient sureties, except for capital offences, when the proof is evident or the presumption great ; and the privilege of the writ of habeas corpus shall not be suspended, unless, when in cases of rebellion or invasion, the public safety may require.

SEC. 8. Every person is entitled to a certain remedy in the laws for all injuries or wrongs which he may receive in his person, property, or character; he ought to obtain justice freely and without purchase; completely and without denial; promptly and without delay, conformable to the laws.

SEc. 9. Treason against the State shall consist only in levying war against the same, or in adhering to its enemies, giving them aid and comfort. No person shall be convicted of treason unless on the testimony of two witnesses to the same overt act, or on confession in open court.

SEC. 10. The right of the people to be secure in their persons, houses, papers, and effects, against unreasonable searches and seizures, shall not be violated; and no warrant shall issue but upon probable cause, supported by oath or affirmation, and

Redress of injuries or wrongs.

Treason defined.

Right against unreasonable searches.

1 The jury contemplated by Article r, Section 6, securing the right to jury trial in criminal cases, is a body of twelve men, and it is error to try a party charged with crime in a justice court, against his objection, with a jury of six. The fact that he may appeal to the district court, on entering into recognizance with sureties, does not change the rule. 14 Minn. 330. 
particularly describing the place to be searched, and the person or things to be seized.

Prohibits ex post facto laws, or laws impairing contracts. Imprisonment for debt.

Property exemption.

Private property for public use.

\section{Military} power subordinate. Lands declared allodial. Leases, when void.

Freedom of conscience.
SEC. I . No bill of attainder, ex post facto law, nor any law impairing the obligation of contracts, shall ever be passed, and no conviction shall work corruption of blood or forfeiture of estate.

SEC. 12. No person shall be imprisoned for debt in this State, ${ }^{1}$ but this shall not prevent the legislature from providing for imprisonment, or holding to bail, persons charged with fraud in contracting said debt. A reasonable amount of property shall be exempt from seizure or sale for the payment of any debt or liability. The amount of such exemption shall be determined by law. [Provided, however, that all property so exempted shall be liable to seizure and sale for any debts incurred to any person for work done or materials furnished in the construction, repair, or improvement of the same; and, provided further, that such liability to seizure and sale shall also extend to all real property for any debt incurred to any laborer or servant for labor or service performed.] ${ }^{2}$

SEc. 13. Private property shall not be taken, destroyed, or damaged for public use without just compensation therefor, first paid or secured. ${ }^{8}$

SEC. 14. The military shall be subordinate to the civil power, and no standing army shall be kept up in this State in time of peace

SEC. I 5. All lands within the State are declared to be allodial, and feudal tenures of every description, with all their incidents, are prohibited. Leases and grants of agricultural lands for a longer period than twenty-one years, hereafter made, in which shall be reserved any rent or service of any kind, shall be void.

SEC. 16. The enumeration of rights in this constitution shall not be construed to deny or impair others retained by and inherent in the people. The right of every man to worship God according to the dictates of his own conscience shall never be infringed, nor shall any man be compelled to attend, erect, or support any place of worship, or to maintain any religious or ecclesiastical ministry, against his consent ; nor shall any control of or interference with the rights of conscience be permitted, or

123 Minn. $1 ; 23$ Minn. 4rr.

2 The clause in brackets was adopted November 6,1888 .

3 The words "destroyed or damaged" inserted by amendment adopted Novem. ber 3,1896 . 
any preference be given by law to any religious establishment or mode of worship; but the liberty of conscience hereby secured shall not be so construed as to excuse acts of licentiousness, or justify practices inconsistent with the peace or safety of the State, nor shall any money be drawn from the treasury for the benefit of any religious societies, or religious or theological seminaries.

SEC. 17. No religious test or amount of property shall ever be required as a qualification for any office of public trust under the State. No religious test or amount of property shall ever be required as a qualification of any voter at any election in this State; nor shall any person be rendered incompetent to give evidence in any court of law or equity in consequence of his opinion upon the subject of religion.

ARTICLE II
Boundaries
[Omitted.]
ARTICLE III
Distribution of the Powers of Government
I. The powers of government shall be divided into
person or persons belonging to or constituting one of
partments shall exercise any of the powers properly be-
in either of the others, except in the instances expressly
in this constitution.

ARTICLE IV

Legislative Department

Section I. The legislature shall consist of the Senate and House of Representatives, which shall meet biennially at the seat of government of the State, at such time as shall be prescribed by law, but no session shall exceed the term of ninety (90) legislative days $;^{1}$ and no new bill shall be introduced in

Division of powers.

No preference to be given to any religious establishment or mode of worship.

No religious test or property qualifcation to be required.

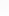


either branch, except on the written request of the governor, during the last twenty (20) days of such sessions, except the attention of the legislature shall be called to some important matter of general interest by a special message from the governor. ${ }^{1}$

Apportionment of members.
Eligibility of members.

Quorum.

Rules of government.

Officers.

Journal of proceedings.

Length of adjournments.

Compensation.
SEC. 2. The number of members who compose the Senate and House of Representatives shall be prescribed by law, but the representatives in the Senate shall never exceed one member for every 5,000 inhabitants, and in the House of Representatives one member for every 2,000 inhabitants. The representation in both houses shall be apportioned equally throughout the different sections of the State, in proportion to the population thereof, exclusive of Indians not taxable under the provisions of law.

SEC. 3. Each house shall be the judge of the election returns and eligibility of its own members $;^{2}$ a majority of each shall constitute a quorum to transact business, but a smaller number may adjourn from day to day, and compel the attendance of absent members in such manner and under such penalties as it may provide.

SEC. 4. Each house may determine the rules of its proceedings, sit upon its own adjournment, punish its members for disorderly behavior, and, with the concurrence of two-thirds, expel a member; but no member shall be expelled the second time for the same offence.

SEC. 5. The House of Representatives shall elect its presiding officer, and the Senate and House of Representatives shall elect such other officers as may be provided by law ; they shall keep journals of their proceedings, and from time to time publish the same, and the yeas and nays, when taken on any question, shall be entered on such journals.

SEC. 6. Neither house shall, during a session of the legislature, adjourn for more than three days (Sundays excepted), nor to any other place than that in which the two houses shall be assembled, without the consent of the other house.

SEC. 7. The compensation of senators and representatives shall be three dollars per diem during the first session, but may

I Amendment adopted November 6, 1888.

2 The election of a State senator or representative to Congress does not necessarily create a vacancy. Senate Fournal, 1889, page 962. See opinion of Attorney General Clapp. 
afterwards be prescribed by law. ${ }^{1}$ But no increase of compensation shall be prescribed which shall take effect during the period for which the members of the existing House of Representatives may have been elected.

SEC. 8. The members of each house shall in all cases, except treason, felony, and breach of the peace, be privileged from arrest during the session of their respective houses, and in going to or returning from the same. For any speech or debate in either house they shall not be questioned in any other place.

SEC. 9. No senator or representative shall, during the time for which he is elected, hold any office under the authority of the United States or the State of Minnesota, except that of postmaster, and no senator or representative shall hold an office under the State which has been created or the emoluments of which have been increased during the session of the legislature of which he was a member, until one year after the expiration of his term of office in the legislature. ${ }^{2}$

SEC. 10. All bills for raising a revenue shall originate in the House of Representatives, but the Senate may propose and concur with amendments as on other bills.

SEC. II. Every bill which shall have passed the Senate and House of Representatives, in conformity to the rules of each house and the joint rules of the two houses, shall, before it becomes a law, be presented to the governor of the State. If he approve, he shall sign and deposit it in the office of secretary of state for preservation, and notify the house where it originated of the fact. But if not, he shall return it, with his objections, to the house in which it shall have originated; when such objections shall be entered at large on the journal of the same, and the house shall proceed to reconsider the bill. If, after such reconsideration, two-thirds of that house shall agree to pass the bill, it shall be sent, together with the objections, to the other house, by which it shall likewise be reconsidered; and if it be approved by twothirds of that house it shall become a law. But in all such cases the votes of both houses shall be determined by yeas and nays, and the names of the persons voting for or against the bill shall be entered on the journal of each house, respectively. If any bill shall not be returned by the governor within three days (Sundays

Privileged from arrest.

Restriction as to holding office.

Bills of revenue to originate in House.

Approval of bills by governor.

Action on nonapproval. 
Governor

- may cut out items of appropriation bills and otherwise approve.

Money appropriations, how made.

Majority vote of all memberselect to pass a law.

Impeachment powers. excepted) after it shall have been presented to him, the same shall be a law in like manner as if he had signed it, unless the legislature, by adjournment within that time, prevents its return; in which case it shall not be a law. The governor may approve, sign, and file in the office of the secretary of state, within three days after the adjournment of the legislature, any act passed during the last three days of the session, and the same shall become a law.

[If any bill presented to the governor contain several items of appropriation of money, he may object to one or more of such items, while approving of the other portion of the bill. In such case he shall append to the bill, at the time of signing it, a statement of the items to which he objects, and the appropriation so objected to shall not take effect. If the legislature be in session, he shall transmit to the house in which the bill originated a copy of such statement, and the items objected to shall be separately reconsidered. If, on consideration, one or more such items be approved by two-thirds of the members elected to each house, the same shall be a part of the law, notwithstanding the objections of the governor. All the provisions of this section, in relation to bills not approved by the governor, shall apply in cases in which he shall withhold his approval from any item or items contained in a bill appropriating money. ${ }^{1}$

SEC. 12. No money shall be appropriated except by bill Every order, resolution, or vote requiring the concurrence of the two houses (except such as relate to the business or adjournment of the same) shall be presented to the governor for his signature, and, before the same shall take effect, shall be approved by him, or, being returned by him with his objections, shall be repassed by two-thirds of the members of the two houses, according to the rules and limitations prescribed in case of a bill.

SEC. 13. The style of all laws of this State shall be: "Be it enacted by the Legislature of the State of Minnesota." No law shall be passed unless voted for by a majority of all the members elected to each branch of the legislature, and the vote entered upon the journal of each house.

SEC. I4. The House of Representatives shall have the sole power of impeachment, through a concurrence of a majority of all the members elected to seats therein. All impeachments shall 
be tried by the Senate; and when sitting for that purpose the senators shall be upon oath or affirmation to do justice according to law and evidence. No person shall be convicted without the concurrence of two-thirds of the members present.

SEc. 15. The legislature shall have full power to exclude from the privilege of electing or being elected any person convicted of bribery, perjury, or any other infamous crime.

SEC. 16. Two or more members of either house shall have liberty to dissent and protest against any act or resolution which they may think injurious to the public or to any individual, and

Exclusion from civil rights.

Protest and dissent of members.

Vacancies in legislature. vacancies as may occur in either house of the legislature. The legislature shall prescribe by law the manner in which evidence in cases of contested seats in either house shall be taken.

SEc. 18. Each house may punish by imprisonment, during its session, any person, not a member, who shall be guilty of any disorderly or contemptuous behavior in their presence, jut no such imprisonment shall at any time exceed twenty-four hours.

SEC. 19. Each house shall be open to the public during the sessions thereof, except in such cases as in their opinion may require secrecy.

SEC. 20. Every bill shall be read on three different days in each separate house, unless, in case of urgency, two-thirds of the house where such bill is depending shall deem it expedient to dispense with this rule; and no bill shall be passed by either house until it shall have been previously read twice at length. 1

SEC. 21. Every bill having passed both houses shall be carefully enrolled, and shall be signed by the presiding officer of each house. Any presiding officer refusing to sign a bill which shall have previously passed both houses shall thereafter be incapable of holding a seat in either branch of the legislature, or hold any other office of honor or profit in the State, and in case of such refusal, each house shall, by rule, provide the manner in which such bill shall be properly certified for presentation to the governor.

1 Provision as to manner of passing bills is imperative and not directory. 2 Minn. 330.
Punish for disorderly conduct.

Open sessions.

Reading of bills.

Enrolment of bills. 
Passage of bills on last day of session prohibited.

Census enumeration.

Apportionment.

Senatorial districts term of office of senators and representatives.
Qualification of legislators.
SEC. 22. No bill shall be passed by either house of the legislature upon the day prescribed for the adjournment of the two houses. But this section shall not be so construed as to preclude the enrolment of a bill, or the signature and passage from one house to the other, or the reports thereon from committees, or its transmission to the executive for his signature.

SEC. 23. The legislature shall provide by law for an enumeration of the inhabitants of this State in the year one thousand eight hundred and sixty-five, and every tenth year thereafter. At their first session after each enumeration so made, and also at their first session after each enumeration made by the authority of the United States, the legislature shall have the power to prescribe the bounds of congressional, senatorial, and representative districts, and to apportion anew the senators and representatives among the several districts according to the provisions of section second of this article.

SEC. 24. The senators shall also be chosen by single districts of convenient contiguous territory, at the same time that members of the house of representatives are required to be chosen, and in the same manner; and no representative district shall be divided in the formation of a senate district. The senate districts shall be numbered in a regular series. The terms of office of senators and representatives shall be the same as now prescribed by law until the general election of the year one thousand eight hundred and seventy-eight (1878), at which time there shall be an entire new election of all the senators and representatives. Representatives chosen at such election, or at any election thereafter, shall hold their office for the term of two years, except it be to fill a vacancy; and the senators chosen at such election by districts designated as odd numbers shall go out of office at the expiration of the second year, and senators chosen by districts designated by even numbers shall go out of office at the expiration of the fourth year; and thereafter senators shall be chosen for four years, except there shall be an entire new election of all the senators at the election of representatives next succeeding each new apportionment provided for in this article.

SEC. 25. Senators and representatives shall be qualified voters of the State, and shall have resided one year in the State and six months immediately preceding the election in the district from which they are elected. 
SEc. 26. Members of the Senate of the United States from this State shall be elected by the two houses of the legislature in joint convention, at such time and in such manner as may be provided by law.

SEC. 27. No law shall embrace more than one subject, which shall be expressed in its title.

SEC. 28. Divorces shall not be granted by the legislature.

SEC. 29. All members and officers of both branches of the legislature shall, before entering upon the duties of their respective trusts, take and subscribe an oath or affirmation to support the Constitution of the United States, the Constitution of the State of Minnesota, and faithfully and impartially to discharge the duties devolving upon him as such member or officer.

SEc. 30. In all elections to be made by the legislature, the members thereof shall vote viva voce, and their votes shall be entered on the journal.

SEC. 31. The legislature shall never authorize any lottery, or the sale of lottery tickets.

SEC. $32[a]$. Any law providing for the repeal or amendment of any law or laws heretofore or hereafter enacted, which provides that any railroad company now existing in this State or operating its road therein, or which may be hereafter organized, shall, in lieu of all other taxes and assessments upon their real estate, roads, rolling stock, and other personal property, at and during the time and periods therein specified, pay into the treasury of this State a certain percentage therein mentioned of the gross earnings of such railroad companies now existing or hereafter organized, shall, before the same shall take effect or be in force, be submitted to a vote of the people of the State, and be adopted and ratified by a majority of the electors of the State voting at the election at which the same shall be submitted to them.

SEC. 33. In all cases when a general law can be made applicable, no special law shall be enacted; and whether a general law could have been made applicable in any case is hereby Against special legislation. declared a judicial question, and as such shall be judicially determined without regard to any legislative assertion on that subject. The legislature shall pass no local or special law regulating the affairs of, or incorporating, erecting, or changing the lines of, any county, city, village, township, ward, or school

Elections viva voce.

Prohibition of lotteries.

Change of form of taxation of railroads to be voted upon. egislation. 
district, or creating the offices, or prescribing the powers and duties of the officers of, or fixing or relating to the compensation, salary, or fees of the same, or the mode of election or appointment thereto, authorizing the laying out, opening, altering, vacating, or maintaining roads, highways, streets, or alleys ; remitting fines, penalties, or forfeitures ; regulating the powers, duties, and practice of justices of the peace, magistrates, and constables; changing the names of persons, places, lakes, or rivers ; for opening and conducting of elections, or fixing or changing the places of voting; authorizing the adoption or legitimation of children; changing the law of descent or succession; conferring rights upon minors; declaring any named person of age ; giving effect to informal or invalid wills or deeds, or affecting the estates of minors or persons under disability; locating or changing county seats; regulating the management of public schools, the building or repairing of schoolhouses, and the raising of money for such purposes; exempting property from taxation, or regulating the rate of interest on money; creating corporations, or amending, renewing, extending, or explaining the charters thereof; granting to any corporation, association, or individual any special or exclusive privilege, immunity, or franchise whatever, or authorizing public taxation for a private purpose. Provided, however, That the inhibitions of local or special laws in this section shall not be construed to prevent the passage of general laws on any of the subjects enumerated.

Repeal of existing special laws.

Refers to amendment of $\mathrm{r} 88 \mathrm{r}$, superseded as above.

The legislature may repeal any existing special or local law, but shall not amend, extend, or modify any of the same. ${ }^{1}$

SEC. 34. The legislature shall provide general laws for the transaction of any business that may be prohibited by section one ( 1 ) of this amendment, and all such laws shall be uniform in their operation throughout the State. ${ }^{2}$

SEc. 35. Any combinations of persons, either as individuals or as members or officers of any corporation, to monopolize the

1 Adopted November 8, 1892 .

2 Adopted November 8, $188 \mathrm{r}$. This section, having been a part of the amendment, regulating special legislation, adopted in $\mathrm{r} 88 \mathrm{x}$, should properly have been included in the substitution of the amendment of 1892 ; but as it was not referred to by section, in the law submitted to the people, it must perforce remain in the Constitution, however inapplicable its reading. 
markets for food products in this State, or to interfere with, or restrict the freedom of such markets, is hereby declared to be a criminal conspiracy, and shall be punished in such manner as the legislature may provide. ${ }^{1}$

SEC. 36. Any city or village in this State may frame a charter for its own government as a city consistent with and subject to the laws of this State, as follows: The legislature shall provide, under such restrictions as it deems proper, for a board of fifteen freeholders, who shall be and for the past five years shall have been qualified voters thereof, to be appointed by the district judges of the judicial district in which the city or village is situated, as the legislature may determine, for a term in no event to exceed six years, which board shall, within six months after its appointment, return to the chief magistrate of said city or village a draft of said charter, signed by the members of said board, or a majority thereof. Such charter shall be submitted to the qualified voters of such city or village at the next election thereafter, and if four-sevenths of the qualified voters voting at such election shall ratify the same it shall, at the end of thirty days thereafter, become the charter of such city or village as a city, and supersede any existing charter or amendments thereof; provided, that in cities having patrol limits now established, such charter shall require a three-fourths majority vote of the qualified voters voting at such election to change the patrol limits now established.

Before any city shall incorporate under this act the legislature shall prescribe by law the general limits within which such charter shall be framed. Duplicate certificates shall be made setting forth the charter proposed and its ratification, which shall be signed by the chief magistrate of said city or village and authenticated by its corporate seal. One of said certificates shall be deposited in the office of secretary of state, and the other, after being recorded in the office of the register of deeds for the county in which such city or village lies, shall be deposited among the archives of such city or village, and all courts shall take judicial notice thereof. Such charter so deposited may be amended by proposal therefor made by a board of fifteen comAmendment of charter. missioners aforesaid, published for at least thirty days in three

Legislature to prescribe general limits of charter.
Against combinations or pools to affect markets.

City or village may frame its own charter.

Charter to be submitted to voters. 
newspapers of general circulation in such city or village, and accepted by three-fifths of the qualified voters of such city or village voting at the next election, and not otherwise; but such charter shall always be in harmony with and subject to the Constitution and laws of the State of Minnesota. The legislature may prescribe the duties of the commission relative to submitting amendments of charter to the vote of the people, and shall

Upon application of five per cent of legal voters.

Mayor and legislative body.

Articles of amendment may be submitted separately.

General laws for cities by divisions of population. provide that upon application of five per cent of the legal voters of any such city or village, by written petition, such commission shall submit to the vote of the people proposed amendments to such charter set forth in said petition. The board of freeholders above provided for shall be permanent, and all the vacancies by death, disability to perform duties, resignation, or removal from the corporate limits, or expiration of term of office, shall be filled by appointment in the same manner as the original board was created, and said board shall always contain its full complement of members.

It shall be a feature of all such charters that there shall be provided, among other things, for a mayor or chief magistrate, and a legislative body of either one or two houses; if of two houses, at least one of them shall be elected by general vote of the electors.

In submitting any such charter or amendment thereto to the qualified voters of such city or village, any alternate section or article may be presented for the choice of the voters, and may be voted on separately without prejudice to other articles or sections of the charter or any amendments thereto.

The legislature may provide general laws relating to affairs of cities, the application of which may be limited to cities of over fifty thousand inhabitants, or to cities of fifty and not less than twenty thousand inhabitants, or to cities of twenty and not less than ten thousand inhabitants, or to cities of ten thousand inhabitants or less, which shall apply equally to all such cities of either class, and which shall be paramount while in force to the provisions relating to the same matter included in the local charter herein provided for. But no local charter, provision, or ordinance passed thereunder shall supersede any general law of the State defining or punishing crimes or misdemeanors. ${ }^{1}$ 


\section{Article V \\ Executive Department}

Section I. The executive department shall consist of a governor, lieutenant governor, secretary of state, auditor, treasurer, and attorney general, who shall be chosen by the electors of the State. ${ }^{1}$

SEC. 2. ${ }^{2}$ The returns of every election for the officers named in the foregoing section shall be made to the secretary of state, who shall call to his assistance two or more of the judges of the supreme court, and two disinterested judges of the district courts of the State, who shall constitute a board of canvassers, who shall open and canvass said returns and declare the result within three days after such canvass.

SEC. 3. The term of office for the governor and lieutenant governor shall be two years, and until their successors are chosen and qualified. Each shall have attained the age of twenty-five (25) years, and shall have been a bona fide resident of the State for one year next preceding his election. Both shall be citizens of the United States.

SEC. 4. The governor shall communicate by message to each session of the legislature such information touching the State and condition of the country as he may deem expedient. He shall be commander-in-chief of the military and naval forces, and may call out such forces to execute the laws, suppress insurrection, and repel invasion. He may require the opinion, in writing, of the principal officer in each of the executive departments, upon any subject relating to the duties of their respective offices $;{ }^{8}$ and he shall have power, in conjunction with the board of pardons, of which the governor shall be ex-officio a member, and the other members of which shall consist of the attorney general of the State of Minnesota, and the chief justice of the supreme court of the State of Minnesota, and whose powers and duties shall be

1 An executive officer of the State is not subject to the control or interference of the judiciary in the performance of duties belonging to him as an executive officer, and no act done or threatened to be done by him in his official capacity can be brought under judicial control or interference by mandamus or injunction, even when the act is purely ministerial. 29 Minn. 555.

As amended November 6,1877 .

s Adopted November 3, 1896 .

Official term of governor and lieutenant governor - qualifications.

Powers and duties of governor.

Officers in executive department.

Election returns to be sent to secretary of state. governor. 
defined and regulated by law, to grant reprieves and pardons after conviction for offences against the State, except in cases of impeachment. He shall have power, by and with the advice and consent of the Senate, to appoint a State librarian and notaries public, and such other officers as may be provided by law. He shall have power to appoint commissioners to take the acknowledgment of deeds or other instruments in writing, to be used in the State. He shall have a negative upon all laws passed by the legislature, under such rules and limitations as are in this Constitution prescribed. He may on extraordinary occasions convene both houses of the legislature. He shall take care that the laws be faithfully executed, fill any vacancy that may occur in the office of secretary of state, treasurer, auditor, attorney general, and such other State and district offices as may be hereafter created by law, until the next annual election, and until their successors are chosen and qualified.

Official term of other executive officers.

Duties of lieutenant governor.

Official terms of first State officers.

[Obsolete.]

SEC. 5. The official term of the secretary of state, treasurer, and attorney general shall be two (2) years. The official term of the State auditor shall be four (4) years, and each shall continue in office until his successor shall have been elected and qualified. The further duties and salaries of said executive officers shall each be prescribed by law. ${ }^{1}$

SEC. 6. The lieutenant governor shall be ex-officio president of the Senate; and in case a vacancy shall occur, from any cause whatever, in the office of governor, he shall be governor during such vacancy. The compensation of the lieutenant governor shall be double the compensation of a State senator. Before the close of each session of the Senate they shall elect a president pro tempore, who shall be lieutenant governor in case a vacancy should occur in that office.

SEC. 7. The term of each of the executive officers named in this article shall commence on taking the oath of office on or after the first day of May, 1858 , and continue until the first Monday of January, 1860, except the auditor, who shall continue in office till the first Monday of January, 1861, and until their successors shall have been duly elected and qualified ; and the same abovementioned time for qualification and entry upon the duties of their respective offices shall extend and apply to all other officers

1 Adopted November 6, 1883. 
elected under the State Constitution, who have not already taken the oath of office, and commenced the performance of their official duties. ${ }^{1}$

SEC. 8. Each officer created by this article shall, before entering upon his duties, take an oath or affirmation to support the Constitution of the United States and of this State, and faithfully discharge the duties of his office to the best of his judgment and ability.

SEC. 9. Laws shall be passed at the first session of the legislature after the State is admitted into the Union to carry out the provisions of this article.

\section{ARTICLe VI}

\section{Judiciary}

Secrion I. The judicial power of the State shall be vested in a supreme court, district courts, courts of probate, justices of the peace, and such other courts, inferior to the supreme court, as the legislature may from time to time establish by a two-thirds vote. ${ }^{2}$

SEC. 2. The supreme court shall consist of one chief justice and two associate justices, but the number of the associate justices may be increased to a number not exceeding four, by the legislature, by a two-thirds vote, when it shall be deemed necessary. It shall have original jurisdiction in such remedial cases as may be prescribed by law, and appellate jurisdiction in all cases, both in law and equity, but there shall be no trial by jury in said court. It shall hold one or more terms in each year, as the legislature may direct, at the seat of government, and the legislature may provide, by a two-thirds vote, that one term in each year shall be held in each or any judicial district. It shall be the duty of such court to appoint a reporter of its decisions. There shall be chosen, by the qualified electors of the State, one clerk of the supreme court, who shall hold his office for the term of four years, and until his successor is duly elected and qualified, and the judges

Oath of office to be taken by State officers.

[Obsolete.]
Supreme court.

Jurisdiction and powers.

Reporter of decisions.

Clerk of supreme court.

1 This section was adopted April 15, 1858.

Article VI, section 1. The provision of Article VI, section I, vesting the judicial powers of the State in the courts specified therein, is not infringed by the statute authorizing the appointment of and trial of cases before referees, who are merely subordinate officers of the courts, acting only in an intermediate capacity. 5 Minn. 78. 
Election and term of office for judges.

District judges may act where supreme judges are disqualified.

Judicial districts for district courts.

Election of judges.

Term of office and residence.

Jurisdiction of district courts. of the supreme court, or a majority of them, shall have the power to fill any vacancy in the office of clerk of the supreme court until an election can be regularly had.1

SEC. 3. The judges of the supreme court shall be elected by the electors of the State at large, and their term of office shall be six years, and until their successors are elected and qualified.

[Whenever all or a majority of the judges of the supreme court shall, from any cause, be disqualified from sitting in any case in said court, the governor, or, if he shall be interested in the result of such case, then the lieutenant governor, shall assign judges of the district court of the State, who shall sit in such case in place of such disqualified judges, with all the powers and duties of judges of the supreme court. $]^{2}$

SEC. 4. The State shall be divided by the legislature into judicial districts, which shall be composed of contiguous territory, be bounded by county lines, and contain a population as nearly equal as may be practicable. In each judicial district, one or more judges, as the legislature may prescribe, shall be elected by the electors thereof, whose term of office shall be six years, and each of said judges shall severally have and exercise the powers of the court, under such limitations as may be prescribed by law. Every district judge shall, at the time of his election, be a resident of the district for which he shall be elected, and shall reside therein during his continuance in office. In case any court of common pleas heretofore established shall be abolished, the judge of said court may be constituted by the legislature one of the judges of the district court of the district wherein such court has been so established, for a period not exceeding the unexpired term for which he was elected. ${ }^{3}$

SEC. 5. The district courts shall have original jurisdiction in all civil cases, both in law and equity, where the amount in controversy exceeds one hundred dollars, and in all criminal cases where the punishment shall exceed three months' imprisonment or a fine of more than one hundred dollars, and shall have such appellate jurisdiction as may be prescribed by law. The legis-

1 The supreme court shall consist of one chief justice and four associate justices. General Laws, 188x, ch. 141 .

2 Paragraph in brackets added November 7,1876 .

3 This section was adopted November $5, x 875$. 
lature may provide by law that the judge of one district may discharge the duties of judge of any other district not his own, when convenience or the public interest may require it.

SEC. 6. The judges of the supreme and district courts shall be men learned in the law, and shall receive such compensation at stated times as may be prescribed by the legislature; which compensation shall not be diminished during their continuance in office, but they shall receive no other fee or reward for their services.

SEC. 7. There shall be established in each organized county in the State a probate court, which shall be a court of record, and be held at such time and places as may be prescribed by law. It shall be held by one judge, who shall be elected by the voters of the county for the term of two years. He shall be a resident of such county at the time of his election, and reside therein during his continuance in office; and his compensation shall be provided by law. He may appoint his own clerk where none has been elected; but the legislature may authorize the election, by the electors of any county, of one clerk or register of probate for such county, whose powers, duties, term of office, and compensation shall be prescribed by law. A probate court shall have jurisdiction over the estates of deceased persons and persons under guardianship, but no other jurisdiction, except as prescribed by this Constitution.

SEC. 8. The legislature shall provide for the election of a sufficient number of justices of the peace in each county, whose term of office shall be two years, and whose duties and compensation shall be prescribed by law. Provided, That no justice of the peace shall have jurisdiction of any civil cause where the amount in controversy shall exceed one hundred dollars, nor in a criminal cause where the punishment shall exceed three months' imprisonment, or a fine over one hundred dollars, nor in any cause involving the title to real estate.

SEC. 9. All judges other than those provided for in this Constitution shall be elected by the electors of the judicial district, county, or city, for which they shall be created, nor for a longer term than seven years.

SEC. 10. In case the office of any judge become vacant before the expiration of the regular term for which he was elected, the

Qualifications.

Probate court.

Judges to be elected.

Jurisdiction.

Justices of the peace to be elected.

Jurisdiction.

Judges for other courts to be elected.

Vacancies appointment by governor. 
Prohibition of supreme or district judges to hold other offices, or to be voted for office while in office.

Change of judicial districts. Clerk of court.

Legal pleadings.

Court commissionerpowers and jurisdiction.

Elective franchise.

Residence required. vacancy shall be filled by appointment by the governor, until a successor is elected and qualified. And such successor shall be elected at the first annual election that occurs more than thirty days after the vacancy shall have happened.

SEC. II. The justices of the supreme court and the district courts shall hold no office under the United States, nor any other office under this State. And all votes for either of them for any elective office under this Constitution, except a judicial office given by the legislature or the people, during their continuance in office, shall be void.

SEC. 12. The legislature may at any time change the number of judicial districts or their boundaries, when it shall be deemed expedient; but no such change shall vacate the office of any judge.

SEC. 13. There shall be elected in each county where a district court shall be held, one clerk of said court, whose qualifications, duties, and compensation shall be prescribed by law, and whose term of office shall be four years.

SEC. 14. Legal pleadings and proceedings in the courts of this State shall be under the direction of the legislature. The style of all process shall be, "The State of Minnesota," and all indictments shall conclude, "against the peace and dignity of the State of Minnesota."

SEC. 15. The legislature may provide for the election of one person in each organized county in this State, to be called a court commissioner, with judicial power and jurisdiction not exceeding the power and jurisdiction of a judge of the district court at chambers; or the legislature may, instead of such election, confer such power and jurisdiction upon the judge of probate in the State.

\section{ARTICLE VII}

\section{Elective Franchise}

Section 1.1 What persons are entitled to vote:

Every male person of the age of twenty-one (2I) years or upwards belonging to either of the following classes who has resided in this State six (6) months next preceding any election shall be entitled to vote at such election in the election district of which he shall at the time have been for thirty (30) days a

1 Section I adopted November 3, 1896. 
resident, for all officers that now are, or hereafter may be, elective by the people.

First - Citizens of the United States who have been such for the period of three (3) months next preceding any election.

Second-Persons of mixed white and Indian blood, who have adopted the customs and habits of civilization.

Third-Persons of Indian blood residing in this State, who have adopted the language, customs, and habits of civilization, after an examination before any district court of the State, in such manner as may be provided by law, and shall have been pronounced by said court capable of enjoying the rights of citizenship within the State.

SEC. 2. No person not belonging to one of the classes specified in the preceding section; no person who has been convicted of treason or any felony, unless restored to civil rights; and no person under guardianship, or who may be non compos mentis or insane, shall be entitled or permitted to vote at any election in this State.

SEC. 3. For the purpose of voting, no person shall be deemed to have lost a residence by reason of his absence while employed in the service of the United States; nor while engaged upon the waters of this State or of the United States; nor while a student in any seminary of learning; nor while kept at any almshouse or asylum; nor while confined in any public prison.

SEC. 4. No soldier, seaman, or marine in the army or navy of the United States shall be deemed a resident of this State in consequence of being stationed within the same.

SEC. 5. During the day on which any election shall be held, no person shall be arrested by virtue of any civil process.

SEC. 6. All elections shall be by ballot, except for such town officers as may be directed by law to be otherwise chosen.

SEC. 7. Every person who by the provisions of this article shall be entitled to vote at any election shall be eligible to any office which now is, or hereafter shall be, elective by the people in the district wherein he shall have resided thirty days previous to such election, except as otherwise provided in this Constitution, or the Constitution and laws of the United States. ${ }^{1}$

2 Held restrictive and to disqualify a person from holding an elective office who was not eligible at the date of his election, though eligible at the beginning of the term. 45 Minn. 309 .

Residence

not lost in certain cases.

Soldiers and sailors restriction.

Civil process suspended on election day. Elections by ballots.

Right to hold office. 
Women may vote and be eligible.

Official year of the State.

SEC. 8.1 Women may vote for school officers and members of library boards, and shall be eligible to hold any office pertaining to the management of schools or libraries.

Any woman of the age of twenty-one (21) years and upward and possessing the qualifications requisite to a male voter may vote at any election held for the purpose of choosing any officers of schools or any members of library boards, or upon any measure relating to schools or libraries, and shall be eligible to hold any office pertaining to the management of schools and libraries. $^{2}$

SEc. 9. The official year for the State of Minnesota shall commence on the first Monday in January in each year, and all terms of office shall terminate at that time; and the general election shall be held on the first Tuesday after the first Monday in November. The first general election for State and county officers, except judicial officers, after the adoption of this amendment, shall be held in the year A.D. one thousand eight hundred and eighty-four (1884), and thereafter the general election shall be held biennially. All State, county, or other officers elected at any general election, whose terms of office would otherwise expire on the first Monday of January, A.D. one thousand eight hundred and eighty-six (1886), shall hold and continue in such offices, respectively, until the first Monday in January, one thousand eight hundred and eighty-seven (1887).$^{8}$

1 Adopted November 8, 1898 .

2 The right to vote on district school matters was granted by chapter $7 x$, General Laws of 1878 ; and the right to vote for county school superintendents was granted by chapter 204 , General Lazes of 1885 .

3 Adopted November 6, 1883 .

The following parts of the constitution are here omitted : Article VIII. School-funds, Education, and Science. Article IX. Finances of the State, and Banks and Banking. Article X. Of Corporations having no banking privileges. Article XI. Counties and Townships.

Article XII. Of the Militia.

Article XIII. Impeachment and Removal from Office.

Article XIV. Amendments to the Constitution.

Article XV. Miscellaneous subjects.

Schedule. 


\section{$K$. PRESIDENTIAL VOTE OF MINNESOTA}

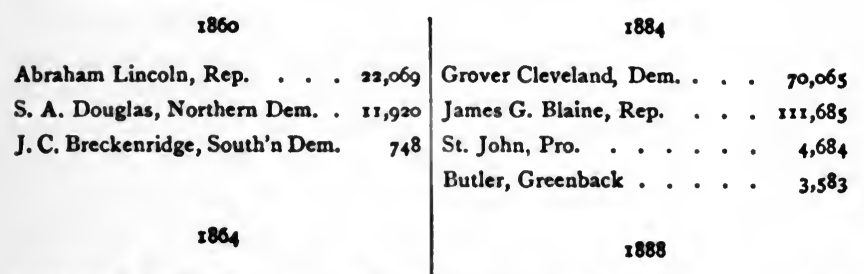

Abraham Lincoln, Rep. . . . 25,055

George B. McClellan, Dem. . 87,367

Benjamin Harrison, Rep. . 142,492

Grover Cleveland, Dem. . . . 104,385

Fisk, Pro. . . . . . . 15,311

1868

U. S. Grant, Rep. . - . . - 43,722

Horatio Seymour, Dem. . . . 28,096

1892

Grover Cleveland, Dem. . . . 100,920

Benjamin Harrison, Rep. . 122,823

James B. Weaver, Peo. . . . 29,313

1872

U. S. Grant, Rep. . . . . 35,708

Horace Greeley, Dem. . . . • 35,211

John Bidwell, Pro. . . . . 14,182

1876

R. B. Hayes, Rep. . • • 72,955

S. J. Tilden, Dem. . . . . $48,5^{87}$

Peter Cooper, Greenback . . 2,389

\section{0}

James A. Garfield, Rep. • . 93,902

W. S. Hancock, Dem. . . . \$33,315

William McKinley, Rep. . . . 193,503

William J. Bryan, Dem.-Pop. 130,735

Joshua Levering, Pro. . . . . 4,338

Palmer, Gold Dem. . . . . . 3,222

Machett, Soc. . . . . 954 James B. Weaver, Greenback $\quad 3,267$ J. B. Harrimann, Soc. Labor 1,329

William McKinley, Rep. . . 190,461 William J. Bryan, Dem.-Pop. . 112,901 John G. Wooley, Pro. . . . . 8,555 E. Debs, Labor . . . . . 3,065 


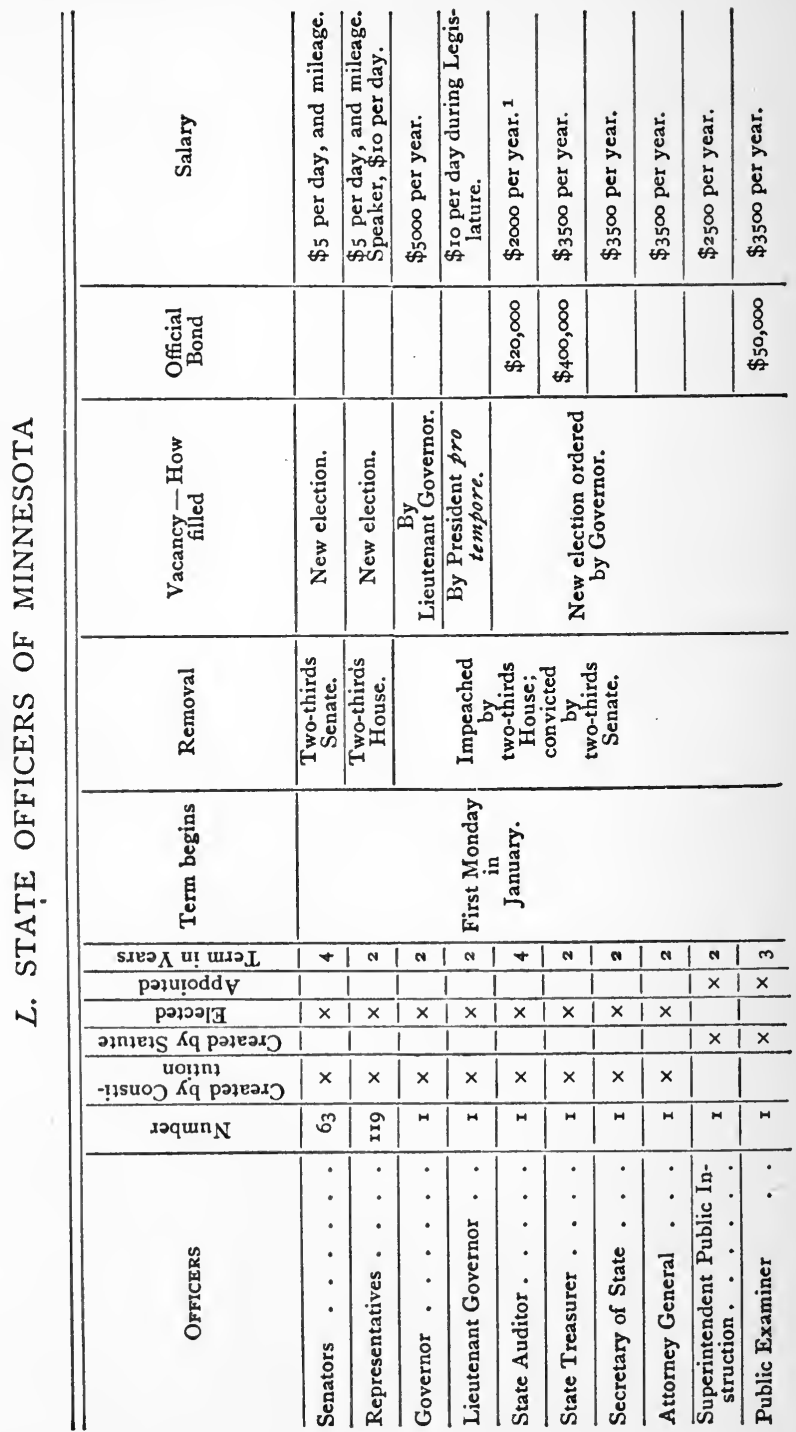



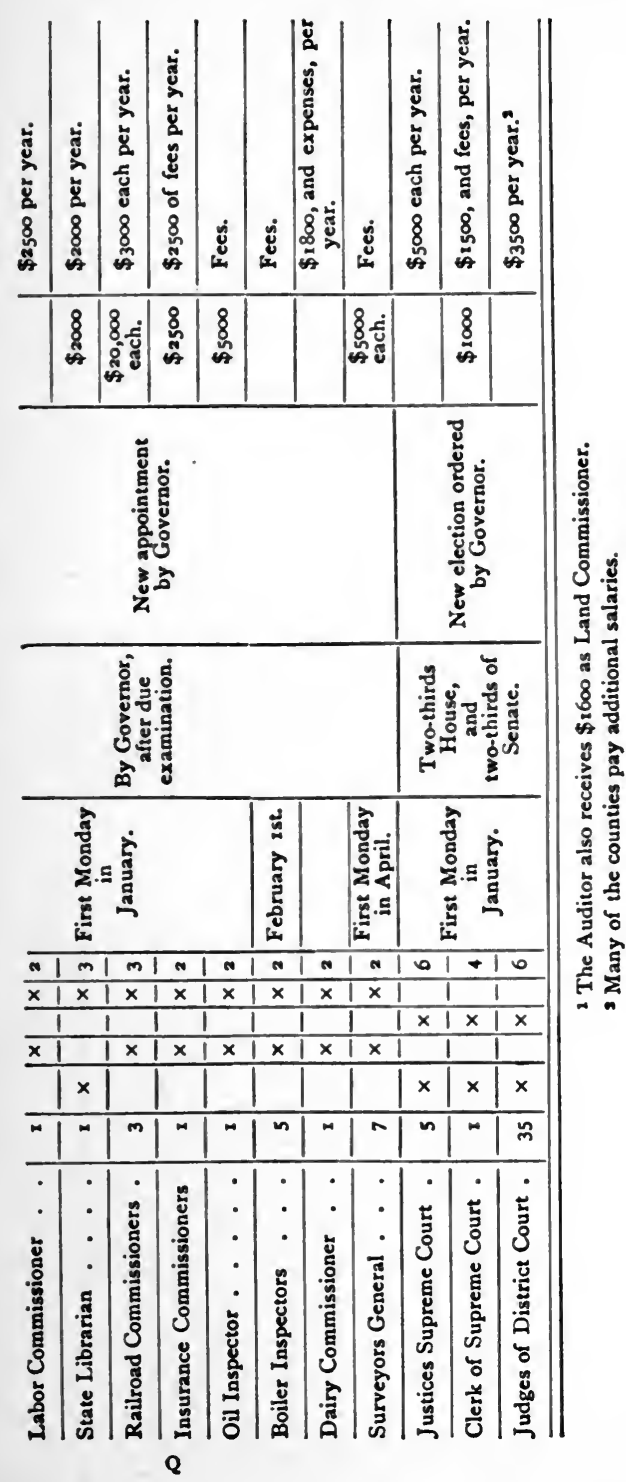


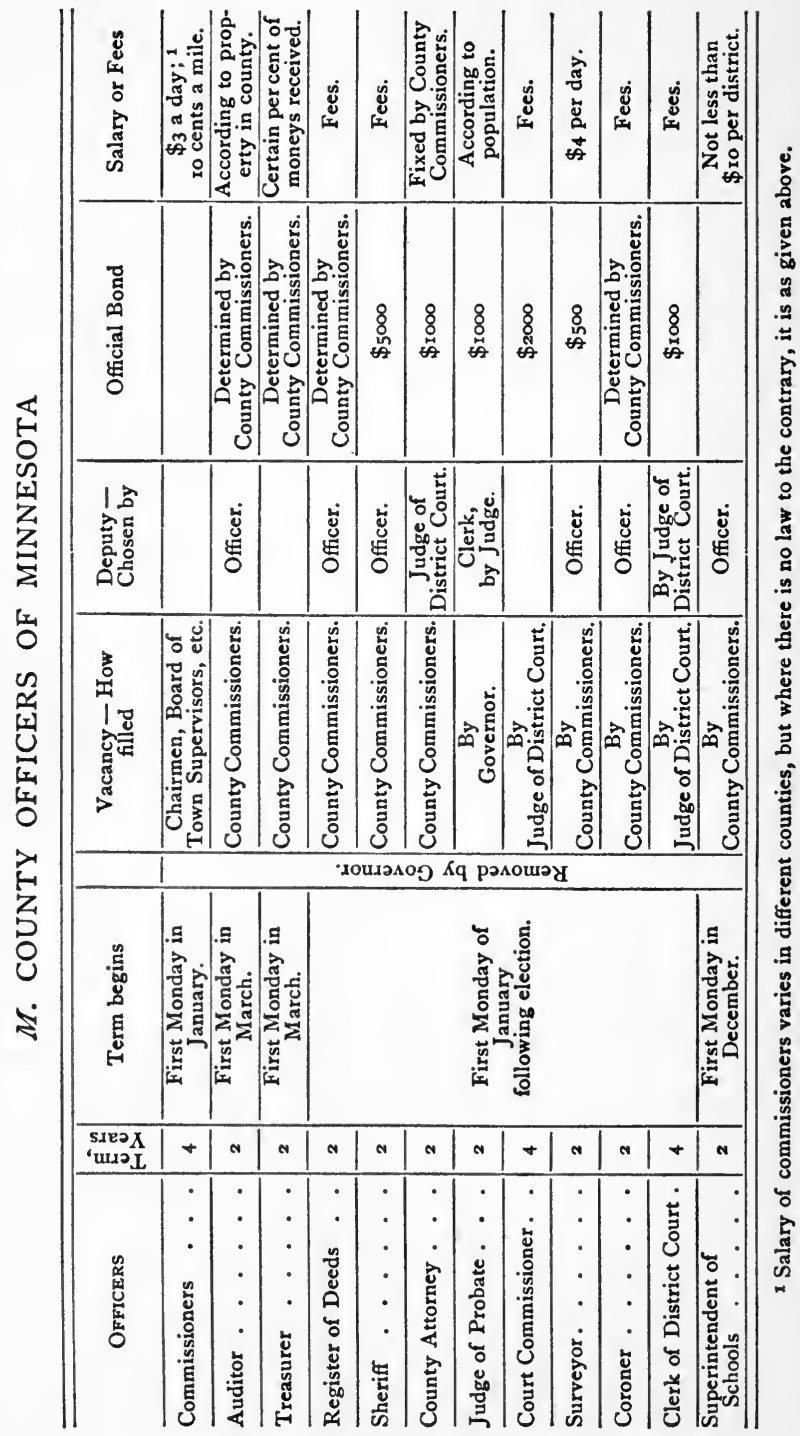




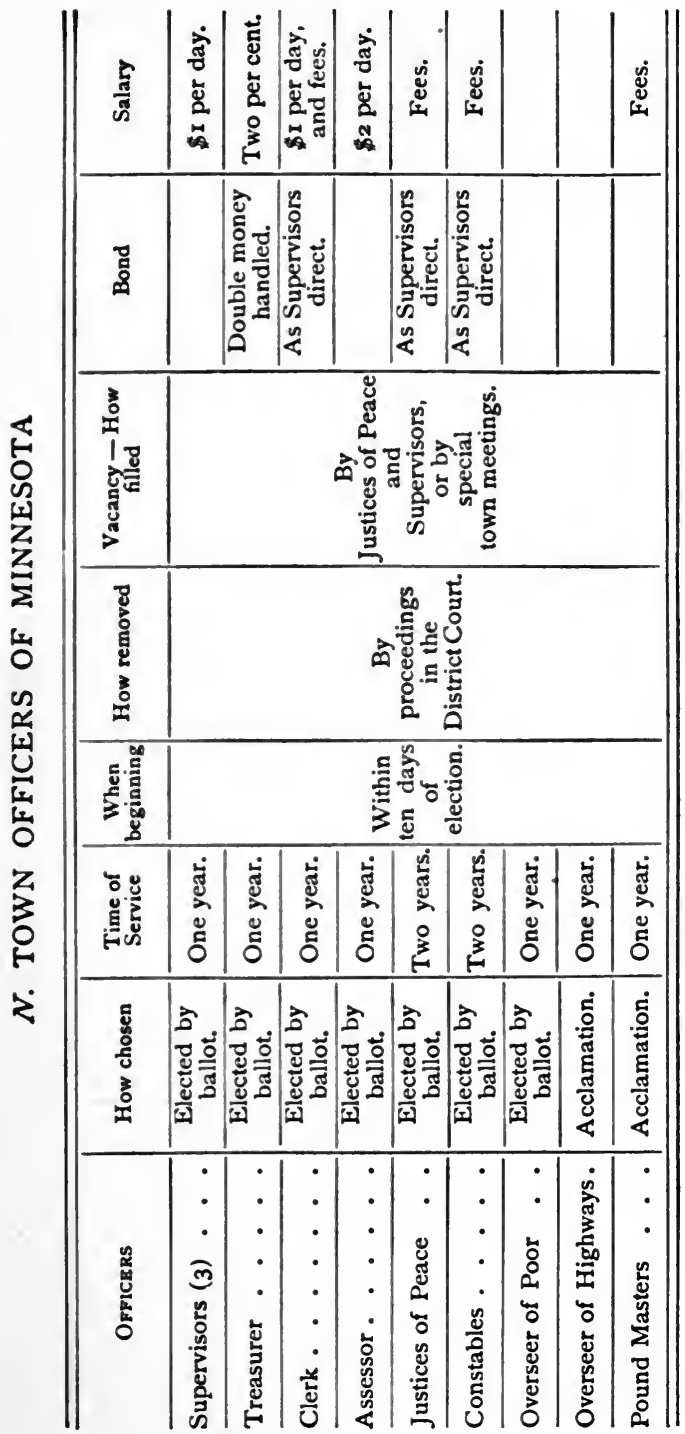




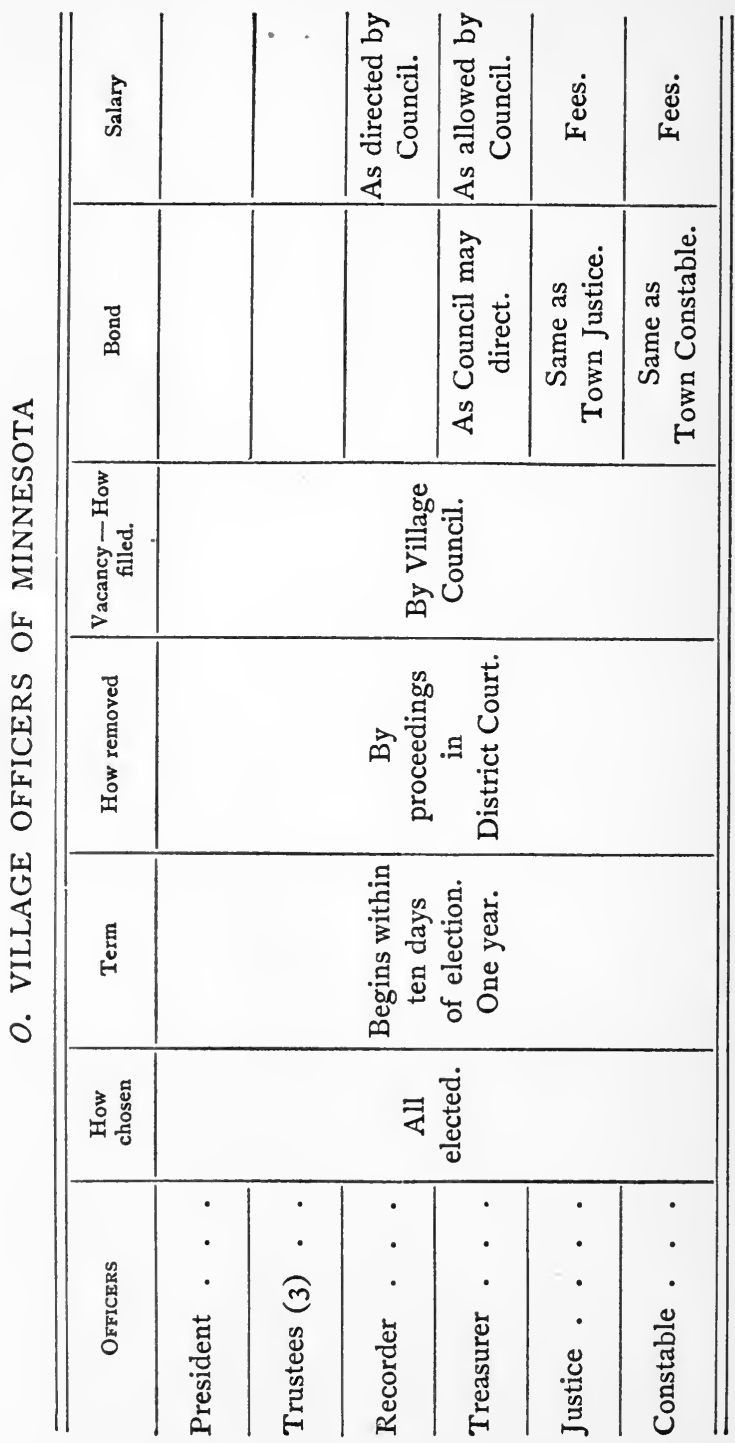




\begin{tabular}{|c|c|c|c|c|c|c|c|c|c|c|c|c|c|c|}
\hline 尝 & 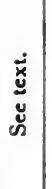 & $\begin{array}{l}\dot{\vec{x}} \\
\stackrel{y}{u} \\
\ddot{y}\end{array}$ & 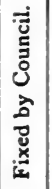 & 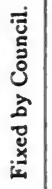 & 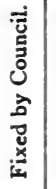 & 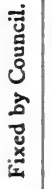 & 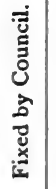 & 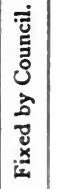 & & 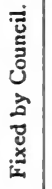 & 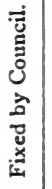 & 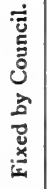 & $\dot{\underline{u}}$ & 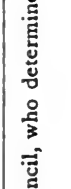 \\
\hline 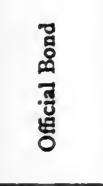 & & & 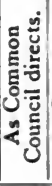 & 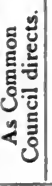 & & & 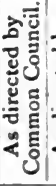 & 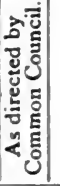 & & & & & 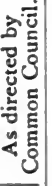 & 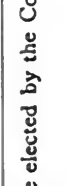 \\
\hline 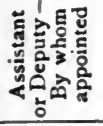 & & & 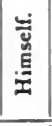 & 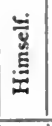 & & & & 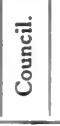 & & 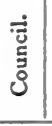 & & & & 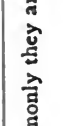 \\
\hline 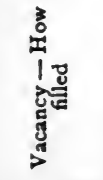 & 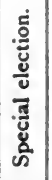 & 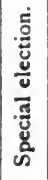 & 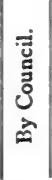 & 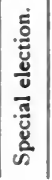 & 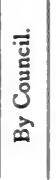 & 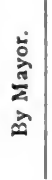 & 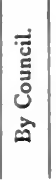 & 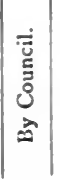 & 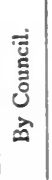 & 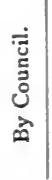 & 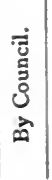 & 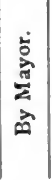 & 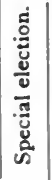 & נं \\
\hline 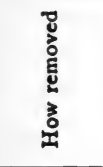 & 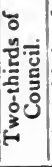 & 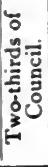 & 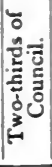 & 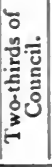 & $\begin{array}{l}\stackrel{0}{0} \\
\frac{\hat{\alpha}}{2} \\
2\end{array}$ & 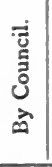 & 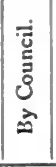 & 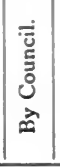 & 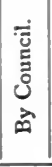 & 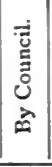 & 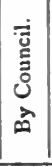 & 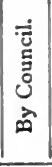 & 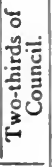 & 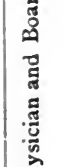 \\
\hline 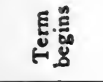 & \multicolumn{13}{|c|}{ '!udV jo Kepsan L puosas } & 胥 \\
\hline $\begin{array}{l}\text { : } \\
0 \\
0 \\
0 \\
0 \\
0 \\
0\end{array}$ & 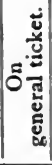 & & نे & 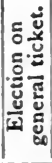 & 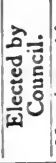 & 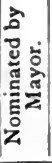 & 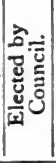 & 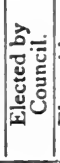 & 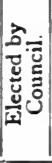 & 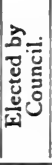 & 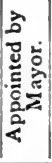 & 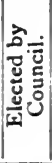 & مَ & 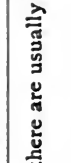 \\
\hline 善 & $\begin{array}{l}\cdot \\
\cdot \\
\dot{0} \\
\text { E } \\
\frac{0}{2}\end{array}$ & $\begin{array}{l}\dot{\cdot} \\
\dot{\cdot} \\
\dot{\cdot} \\
\dot{0} \\
\stackrel{0}{\mathrm{a}}\end{array}$ & 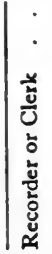 & 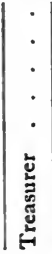 & 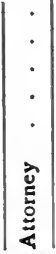 & 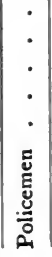 & 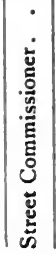 & 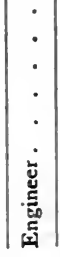 & 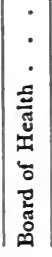 & 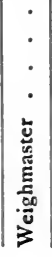 & 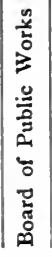 & 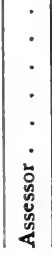 & 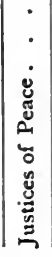 & 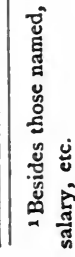 \\
\hline
\end{tabular}




\section{Q. REFERENCES TO MINNESOTA IN THE CONGRESSIONAL DOCUMENTS}

\begin{tabular}{|c|c|c|c|c|c|c|c|c|}
\hline Subject & 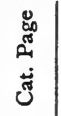 & House & 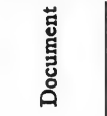 & 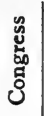 & . 맸 & No. & Vol. & Date \\
\hline Admission . & $\begin{array}{l}710 \\
721\end{array}$ & $\begin{array}{l}\text { Senate } \\
\text { Senate }\end{array}$ & $\begin{array}{c}\text { Rept. } \\
\text { Mis. D. }\end{array}$ & $\begin{array}{l}35 \\
35\end{array}$ & $\begin{array}{l}\text { Ist } \\
\text { Ist }\end{array}$ & $\begin{array}{r}21 \\
209\end{array}$ & $\begin{array}{l}\text { VII. } \\
\text { III. }\end{array}$ & $\begin{array}{l}\text { Jan. } 26,185^{8} \\
\text { Mar. } 30,185^{8}\end{array}$ \\
\hline Boundary . . & $\begin{array}{l}555 \\
785\end{array}$ & $\begin{array}{l}\text { Senate } \\
\text { Senate }\end{array}$ & $\begin{array}{l}\text { Mis. D. } \\
\text { Mis. D. }\end{array}$ & $\begin{array}{l}30 \\
36\end{array}$ & $\begin{array}{l}\text { Ist } \\
2 \mathrm{~d}\end{array}$ & $\begin{array}{r}98 \\
7\end{array}$ & $\begin{array}{r}\text { I. } \\
-\end{array}$ & $\begin{array}{l}\text { Mar. } 28,1848 \\
\text { Dec. } 31,1860\end{array}$ \\
\hline Constitution . & 710 & \multicolumn{7}{|c|}{ Same as Admission Document. } \\
\hline Census . . & $\begin{array}{l}710 \\
727\end{array}$ & House & $\begin{array}{l}\text { Ex. Doc. } \\
\text { Ex. Doc. }\end{array}$ & $\begin{array}{l}35 \\
35\end{array}$ & $\begin{array}{l}\text { Ist } \\
\text { Ist }\end{array}$ & $\begin{array}{r}49 \\
110\end{array}$ & $\begin{array}{r}\text { IX. } \\
\text { XII. }\end{array}$ & $\begin{array}{l}\text { Feb. } \quad 1,185^{8} \\
\text { April }_{30}, 185^{8}\end{array}$ \\
\hline $\left.\begin{array}{c}\text { Expense of the } \\
\text { Territory }\end{array}\right\}$ & $\begin{array}{l}607 \\
626 \\
671\end{array}$ & $\begin{array}{l}\text { House } \\
\text { House } \\
\text { House }\end{array}$ & $\begin{array}{l}\text { Ex. Doc. } \\
\text { Ex. Doc. } \\
\text { Ex. Doc. }\end{array}$ & $\begin{array}{l}32 \\
32 \\
34\end{array}$ & $\begin{array}{l}\text { Ist } \\
\text { 2d } \\
\text { Ist } \\
\end{array}$ & $\begin{array}{l}42 \\
3^{8} \\
59\end{array}$ & $\begin{array}{l}\text { I. } \\
\text { IV. } \\
\text { IX. }\end{array}$ & $\begin{array}{l}\text { Jan. } 22,1852 \\
\text { Feb. } 3,18_{53} \\
\text { Mar. } 17,1856\end{array}$ \\
\hline Exploration. . & 584 & Senate & Ex. Doc. & $3 \mathbf{I}$ & Ist & 42 & $\mathbf{X}$. & Mar. 31, 1850 \\
\hline Land . . . & 662 & House & Ex. Doc. & 33 & $2 \mathrm{~d}$ & 83 & VIII. & Feb. 27,1855 \\
\hline$\overline{\text { Land Grants }}$ & $\begin{array}{r}651 \\
686 \\
882 \\
1003 \\
1063 \\
1121 \\
\end{array}$ & $\begin{array}{l}\text { House } \\
\text { House } \\
\text { Senate } \\
\text { House } \\
\text { House } \\
\text { Senate }\end{array}$ & $\begin{array}{c}\text { Ex. Doc. } \\
\text { Rept. } \\
\text { Rept. } \\
\text { Mis. D. } \\
\text { Mis. D. } \\
\text { Rept. }\end{array}$ & $\begin{array}{l}33 \\
34 \\
40 \\
43 \\
44 \\
45\end{array}$ & $\begin{array}{l}\text { Ist } \\
\text { Ist } \\
\text { 2d } \\
\text { Ist } \\
\text { Ist } \\
\text { 2d } \\
\end{array}$ & \begin{tabular}{|c|} 
r, part 2 \\
344 \\
132 \\
203 \\
130 \\
259 \\
\end{tabular} & $\begin{array}{l}\text { I. } \\
\text { III. } \\
- \\
\text { III. } \\
\text { V. } \\
\text { II. }\end{array}$ & $\begin{array}{l}\text { Sept. } x_{5}, 1854 \\
\text { Aug. } 13,1856 \\
\text { June } 18,1868 \\
\text { Mar. } 16,1874 \\
\text { Mar. } 13,1876 \\
\text { April } 16,1878\end{array}$ \\
\hline Land Settlers . & $\begin{array}{l}1061 \\
1065 \\
\end{array}$ & $\begin{array}{l}\text { Senate } \\
\text { House }\end{array}$ & $\begin{array}{l}\text { Mis. D. } \\
\text { Mis. D. }\end{array}$ & $\begin{array}{l}44 \\
44 \\
\end{array}$ & $\begin{array}{l}\text { Ist } \\
\text { Ist }\end{array}$ & $\begin{array}{r}69 \\
140\end{array}$ & $\begin{array}{l}\text { I. } \\
\text { V. }\end{array}$ & $\begin{array}{l}\text { Mar. 2, } 1876 \\
\text { Mar. 20, } 1876 \\
\end{array}$ \\
\hline adians . . & $\begin{array}{l}642 \\
683 \\
802 \\
809 \\
812 \\
872 \\
910 \\
911 \\
952 \\
819 \\
833 \\
85^{8}\end{array}$ & $\begin{array}{l}\text { House } \\
\text { House } \\
\text { Senate } \\
\text { Senate } \\
\text { House } \\
\text { Senate } \\
\text { House } \\
\text { House } \\
\text { House } \\
\text { Senate } \\
\text { Senate } \\
\text { Senate } \\
\end{array}$ & $\begin{array}{l}\text { Rept. } \\
\text { Ex. Doc. } \\
\text { Mis. D. } \\
\text { Mis. D. } \\
\text { Rept. } \\
\text { Mis. D. } \\
\text { Mis. D. } \\
\text { Mis. D. } \\
\text { Mis. D. } \\
\text { Mis. D. } \\
\text { Mis. D. } \\
\text { Mis. D } \\
\end{array}$ & $\begin{array}{l}33 \\
34 \\
37 \\
37 \\
37 \\
40 \\
41 \\
41 \\
42 \\
38 \\
38 \\
39 \\
\end{array}$ & $\begin{array}{l}\text { Ist } \\
\text { Ist } \\
2 \mathrm{~d} \\
3 \mathrm{~d} \\
3 \mathrm{~d} \\
2 \mathrm{~d} \\
2 \mathrm{~d} \\
2 \mathrm{~d} \\
2 \mathrm{~d} \\
\text { Ist } \\
2 \mathrm{~d} \\
2 \mathrm{~d} \\
\end{array}$ & $\begin{array}{r}138 \\
134 \\
77 \\
7 \\
13 \\
26 \\
104 \\
120 \\
150 \\
37 \\
30 \\
28 \\
\end{array}$ & $\begin{array}{r}\text { II. } \\
\text { XII. } \\
- \\
- \\
- \\
\text { I. } \\
\text { III. } \\
\text { III. } \\
\text { III. } \\
\text { I. } \\
\text { I. } \\
\text { I. }\end{array}$ & $\begin{array}{l}\text { April } 28,1854 \\
\text { July } 24,1856 \\
\text { April } 1,1862 \\
\text { Dec. } 11,1862 \\
\text { Jan. } 26,1863 \\
\text { Feb. } 7,1868 \\
\text { Mar. } 28,1870 \\
\text { April } 4,1870 \\
\text { Mar. } 25,1872 \\
\text { Feb. } 1,1864 \\
\text { Feb. } 11,1865 \\
\text { Feb. } 18,1868 \\
\end{array}$ \\
\hline Judicial Dist. . & 802 & Senate & Mis. D. & 37 & $2 \mathrm{~d}$ & 73 & - & Mar. 26,1862 \\
\hline
\end{tabular}


References to Minnesota. - Concluded

\begin{tabular}{|c|c|c|c|c|c|c|c|c|}
\hline Surject & $\begin{array}{l}\stackrel{8}{0} \\
\dot{\pi} \\
\dot{\pi}\end{array}$ & House & 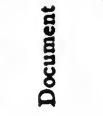 & 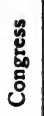 & . & No. & Vol. & Date \\
\hline \multirow{2}{*}{$\begin{array}{c}\text { Public Build- } \\
\text { ings }\end{array}$} & $63^{6}$ & House & Ex. Doc. & 33 & ist & 48 & vilI. & Feb. 6,1854 \\
\hline & $6 \times 2$ & House & Ex. Doc. & 32 & sst & 85 & VI. & Mar. 4,1852 \\
\hline \multirow{3}{*}{$\begin{array}{l}\text { Terr. Govern't. } \\
\text { Ag. College. }\end{array}$} & 1890 & House & Rept. & 46 & ad & $73 x$ & III. & April 6, 1880 \\
\hline & $8 \times 3$ & Senate & Mis. D. & 37 & $3 \mathrm{~d}$ & 25 & - & Feb. 13,1863 \\
\hline & 587 & House & Rept. & 30 & Ist & 270 & II. & April 11, 1850 \\
\hline Schools . . & 686 & House & Rept. & 34 & Ist & 344 & III. & Aug. 13,1856 \\
\hline \multirow[t]{3}{*}{ Swamps . . } & 822 & Senate & Mis. D. & $3^{8}$ & rst & 62 & I. & Mar. 10, 1864 \\
\hline & 999 & House & Rept. & 43 & Ist & 149 & I. & Feb. 24,1874 \\
\hline & 1190 & House & Rept. & 46 & 2d & 732 & III. & April 6,1880 \\
\hline Settlers' Rights & 1056 & House & Mis. D. & 44 & sst & 73 & II. & Jan. $3^{x}, 1876$ \\
\hline & 1067 & House & Mis. D. & 44 & Ist & $\times 58$ & v. & April 3,1876 \\
\hline $\begin{array}{l}\text { Currency } \\
\text { Finance }\end{array}$ & 858 & Senate & Mis. D. & 39 & $2 d$ & 29 & I. & Feb. 18,1867 \\
\hline Railroads . & 662 & Senate & Rept. & 33 & $\overline{2 d}$ & 547 & I. & Feb. 27,1855 \\
\hline & 789 & House & Mis. D. & 36 & 2d & 36 & 一 & Feb. 6,186 \\
\hline & 799 & Senate & Mis. D. & 37 & $2 d$ & 55 & 一 & Feb. 24,1862 \\
\hline & 820 & Senate & Mis. D. & $3^{8}$ & ist & 38 & I. & Feb. 8,1864 \\
\hline & 833 & Senate & Mis. $\mathbf{D}$. & $3^{8}$ & $2 d$ & 22 & I. & Feb. $x, 1865$ \\
\hline & 834 & Senate & Mis. D. & $3^{8}$ & 2d & 34 & I. & Feb. 14,1865 \\
\hline & 862 & Senate & Mis. D. & 40 & sst & 20 & - & Mar. 22,1867 \\
\hline & 872 & Senate & Mis. D. & 40 & $2 d$ & 27 & I. & Feb. 7,1868 \\
\hline & 876 & Senate & Mis. D. & 40 & $2 d$ & 54 & I. & Mar. 21, 1868 \\
\hline & 878 & Senate & Mis. D. & 40 & 2d & 73 & I. & April 6,1868 \\
\hline & 908 & Senate & Mis. D. & 41 & $2 d$ & $8 \mathrm{I}$ & I. & Mar. 14,1870 \\
\hline & 909 & House & Mis. D. & $4 x$ & $\mathbf{2 d}$ & 90 & III. & Mar. 17,1870 \\
\hline & 1102 & Senate & Mis. D. & 43 & ist & 80 & I. & Mar. 6,1874 \\
\hline & 1055 & House & Mis. D. & 44 & $2 d$ & 72 & II. & Jan. 31,1876 \\
\hline & 1065 & House & Mis. D. & 44 & ist & 138 & v. & Mar. 20,1876 \\
\hline & 3107 & House & Rept. & 45 & $2 d$ & 120 & I. & Feb. $\quad 5, \times 878$ \\
\hline
\end{tabular}





\section{N D E X}

Actions, civil and criminal, 110 ; in justice of peace court, III.

Adjutant general, 169.

Alderman, 80; Duluth, 88; Minneapolis, 84 ; St. Paul, 87 ; salaries, 80.

Allouez, 5.

Amendment of constitution, 4I, 42 .

American Fur Company, 10.

Appropriation bills, 57 .

Arrest, examination, 121 ; warrant, 121.

Assessments, review of, 131.

Attorney, county, 67; general duty, 51 ; pardons, 167 .

Auditor, county, 64 ; county in elections, 108; State, 5 r.

Bail, admitted to, 121 .

Ballots, preparation, I03 i printing, 98.

Bill of rights, 40.

Bills, passing, 55-56, 57 .

Boards, care of insane, 162 ; charities and correction, 167; city, 82, 133: and commissions, 52-53: Duluth, 91; high school, 148; Minneapolis, 84; normal school, $15 \mathrm{I}$; of equalization, 131-132; of pardon, 167: of St. Paul, 87; of State training school, 164.

Bribery, elections, 99.

Candidates, fees, 99 ; nomination, 93.

Canvassing of elections, 105-107.

Cass, Lewis, governor, 7.

Catlin, John, 12.

Charities and correction, board of, $55,167$.

Charter, commissions, 76-78; Duluth, 88-90; Minneapolis, 84; new in Minneapolis, 85; St. Paul, 8688 ; steps in securing, 77 .

Charters, and villages, 76 .

Cities, civil service, 83 ; classification, 78 ; comptroller and treasurer, 82 ; council powers, 80 ; executive. 80 ; home rule, 76 ; justice of peare, III; municipal courts, II2; municipal ownership, 89; police, 82 : population of, 184-185; wards, 79.

Citizens, Indian, 91 ; militia, 162 ; of U.S. and State, 9I, 16I; restrictions upon, 92 ; women, 91 .

City, boards, 82, 133; indebtedness, $8 \mathrm{I}$; local government, 46 ; offices, 232 ; salaries of officers, 79.

Civil procedure, 116-121.

Civil service, municipal, 83 .

Civil war, Minnesota, 22.

Classes, social number, 158 ; special, 159.

Clerk, of court, 118, 124; supreme court, 58 .

Commissioners, county, 64, 65, 137 .

Commissions and boards, 52-53.

Comptroller, city, 82.

Congress, documents referring to Minnesota, 230; militia, 159, 168.

Constitution, amendment of 1896,76 ; amendment and revision, 40-4I; and the legislature, 55 ; convention, 19; of Minnesota, 39, 202-222 i of the United States, 39.

Convention, constitutional, 19, 42.

Conventions, party, 97 .

Coroner, duties, 66; relation to sheriff, 67.

Corporations, gross earnings, 136 .

Council, Duluth, 88; Minneapolis, 85; powers, 80; St. Paul, 87; village and town, $74-76$.

Counties, population of, 176-179. 
County, 45 ; attorney, 67 ; auditor, 64 ; auditor in elections, 108; the business of, 62 ; canvassing elections, 107 ; commissioners, 63; commissioners appeal to district courts, II3; commissioners and villages, 73i commissioners and township, $7 I$; officers, $64,78,226$; organization of, 62-63; powers of, 63; relation to State, 60 ; removal of officers, 68 ; superintendent, 67 ; treasurer of, 65 .

Court, commissioners, 68 ; supreme, new trial, I I9; village, 75 .

Courts, appeal, classification, IIo, II9; civil procedure, II6-120; district, 59; function of, rog; local and district, IIO-III ; military, I73; municipal, 59, II2; probate, 60 , II3; of State, 58-60; supreme, II5 ; supreme judges, 58 .

Crime, actions for, IIO; defined, I2I ; institutions for correction, 163 .

Deeds, register of, 65 .

Defectives, care of, I6I; schools for, I6I.

District court, appeals to, II4 ; jurisdiction of, II4.

Divisions, administrative, 43-47.

Du Lhut, Sieur, 5 .

Duluth, boards, 89 ; charter, $88-89$; municipal ownership, 89; officers, 89; officers' removal, 89 .

Education, 139-157.

Election, campaign committees, 100 ; canvassing boards, 106-108; conduct of, 104-I06; corrupt practices act, 99; expenses of, Ioo; judges of, 105; machinery of, 102; preparation of ballots, I03; primary, 93; registration, IO2; result of corrupt practices act, xor ; senatorial canvassing board, I07 State canvassing board, 107-108.

Enabling act, 196-199; contents, I718; Minnesota, 17 .

English in Minnesota, 6-7.

Equalization boards, I3I-2.
Executive of the State, 48-50.

Expeditions, 7-8.

Expenditures, checks on, 136; city, I38; of Minnesota, 136 ; of money, 136.

Explorers, 4, 5, 6, 7 .

Farmers' institutes, 154 .

Franchise, Minnesota, 90-93; the law of, 9I.

French explorers, 4,5 .

Government, act to establish the Territory, 186-195; central, 43-44, 4860; enabling act, 196-199; local, 44 ; object of, 172 ; organization, $2 \mathrm{x}$. Governor, appropriations, 57 ; board of pardons, 167 ; charities and correction, 167 ; officers appointed by, 5I-52; powers, 49-50; the Territory, 13 .

Governors of Minnesota, 173.

Grosseillier, explorer, 5 .

Habeas Corpus, and prisoner, I2I.

Health, board of, 53; in township, 72.

Hennepin County, commissioners, 64.

Hennepin, Father, 5 .

High schools, I47.

History, chronological arrangement, 3I-37.

Hudson Bay Company, 6.

Impeachment, method and persons impeached, 57 .

Indians, as citizens, $9 \mathrm{I}$; Sioux massacre, 23-26; treaties, ro.

Indictment, defined, 123; drawn by attorney, 68.

Industry, development of, 30-3I.

Insane, care of, 162-163.

Institutions, charitable, $16 \mathrm{I}-16_{3}$; classified, 159 ; cost of, 168 .

Iron, Mesabi and Vermillion ranges, 2.

Issues, in civil trial, II7.

Judges, district courts, 59; duties of election, I05; election, I04; supreme court, 58,115 . 
Judiciary, 44; legislature, 110.

Jury, grand, 122, 123; petit, 118; trial, 40; trial before, Ir9; verdict, 124.

Justice, administration of, I09, 126; city, 112; of peace, 59, III; safeguards, 125.

Land grants to railroads, 27.

Law, greatness of, 126.

Legislature, 44; and charters, 78-79; cities, 77 ; and judiciary, 110; control over local governments, 47 ; limited, 55; meeting, membership, qualifications, 53-54; members of first, 175: method of passing bills, 55-56.

Le Sueur, 5.

Libraries, school, 156; travelling, 156; board of travelling, 157 .

Lieutenant governor, 50 .

Local government, 6I-90; control of legislature over, 47 ; money matters, 138.

Louisiana purchase, 6.

Mayor, appointments, 80; Duluth, 88; Minneapolis, 84; St. Paul, 86; towns and villages, 73,76 ; veto, 81 .

Menard, missionary, 5 .

Mesabi iron range, 2.

Militia, 160; and citizens, 168 ; courts of, 170; enlistment, 170; exceptions to service, 169; expenses of, 171 ; organization, 169; State, 168I71.

Minerals, 3 .

Minneapolis, aldermen, 79 ; boards, 84; charter, 84; new charters, 85; sketch of history, 83-85.

Minnesota, act of admission, 20020I ; admitted, 20; citizens, 90-91; Civil War, 22; Congressional documents referring to, 230; constitution of, 202-222; education in, 139 ; enabling act, 16; governors, 177 ; opposition to admission, 16-17: population, 10; population in 1849 , 175; population by counties, 176 379.
Missionaries, 9, $\mathrm{Xr}$.

Municipal courts, 59 .

Naval reserves, 160; organization, I7x.

Nicollet, Jean, 5.

Nomination by petition, 98 ; candidates, 93.

Normal schools, courses of study, I5I.

Northwest Territory, 11.

Notaries public, 60.

Officers, appointed by governor, 5I52; city, 229; city salaries, 79; county, 226; State, 224-225; township, 72; town, 227 ; village, 228.

Pardons, board of, 166.

Parties, campaign committee of, 100.

Party, convention, 97.

Personal property, taxation of, 134 .

Petition, nomination by, 98 .

Pike, Lieutenant Zebulon, 7.

Police in cities, 82.

Population, cities, 184; growth, 30: growth of, 176-180; Minnesota in 1849, 176; nativity of, 180-185.

Presentment defined, 123.

President, vote for, 1860-1900, 223.

Primary, call for, $96-97$; elections, 93 ; holding of, 94 ; organization, 96 .

Prison, parole system, 166; profits, 166; State, 165.

Probate, court, 59, I13; will in court, II3.

Procedure, civil, I16-121; criminal, 120, 126.

Products of Minnesota, 30-31.

Property, assessment of, 129; assessors of, 130; exempted, 130; tax, real, 134.

Public schools, 139.

Radisson, explorer, 5 .

Railroad commissioners, 53.

Railroads, bonds repudiated, 28; mileage, 29; the State and, 27-29.

Ramsey, Governor, 14-22.

Reformatory, State, 163.

Register of deeds, 65 . 
Registration, election, I02; in cities, I03.

Removals, by governor, 49 .

Representatives, structure of House of, 54; qualifications for membership, 54 .

Revenue, sources of, 128; State, 127138.

Revision of constitution, 4I-42.

St. Paul, boards, 87 ; council, 87 ; history and charter, $85-87$; mayor and officers, 86.

Schoolcraft, explorer, 8.

Schools, administration, 146; common, 142 ; county superintendent, 68; districts, I40-143; division of, I46; for defectives, 163 ; grading of, 143; growth of system, 139; high schools, I40; independent school districts, 142 ; normal schools, 140 ; organization of, I4I ; rural, $\mathrm{x}_{46}$; semi-graded and graded, 147 ; State training, 164 ; support of, 144 .

Secretary of State, 50.

Settlements, 8, 9 .

Sheriff, duties, 66.

Sibley, H. H., 13.

Sioux massacre, 23-26.

Soldiers' home, 162.

State, object of, I72; care of children, 161 ; care of insane, 162; citizens, 158 ; cost of institutions to, 168; expenses of militia, $17 \mathrm{r}$; militia, I68-I7I; naval reserves, $17 \mathrm{I}$; offences against, 110 ; officers, 227-228; prison, 165; protection of, 159-172; reformatory, 164; restricted powers, 38 ; revenues, $130-$ 142; Secretary of, 50; soldiers' home, 162; treasurer, 135; university, 152 .

Suffrage, conditions of, 93.

Superintendent of public instruction, I49.

Supreme court, 58-59, II5; new trial, IIg.

Taxation, collection, 134; estimate of, 133; gross earnings, 136 ; kinds of, 128; levying and collection of,
132; of property, 134; personal property, I34; poll-tax, I29; school, 144.

Teachers' certificate, I49.

Territory, act to establish, 186-195; delegate, 13; enabling act, 13, 196; government of, I3, I4, I5; organization, II ; physical, 2.

Text-books, free, 154 .

Topography of the State, 2.

Town officers, 227; board of taxation, $13 \mathrm{I}$; judiciary functions, 46 .

Township, and county commissioners, $7 \mathrm{r}$; defined, 69 ; officers, 72 ; origin, 69; political organization, 70 ; powers, 72.

Traders in Minnesota, 9.

Treasurer, settlement of accounts of, I35; city, 82; county, 65; State, duty, $5 \mathrm{I}$.

Treaties, Indian, Io.

Trial, civil, steps in, 116; criminal, I20; decisions in, I20; new, II9; review of, 125 ; venue, 125 ; verdict, I24.

University of Minnesota, I4I, I52; board of regents, I53; departments and degrees, 152 ; endowment, 14I; geological survey, 154 ; relation to schools, 152 .

Vacancies in State offices, 49.

Venue, change, 125 .

Vermillion iron range, 2.

Veto, governor, 49; legislature, $5^{6}$; mayor, 81.

Village, court, 75 ; officers, 228 ; organization, 73; powers, 74 .

Villages, and charter, 76 ; classes, 75 ; officers, 75 .

Vote, presidential, 1860-1900, 223.

Voters, registered in cities, I03; who are, 90.

Wards, city, 79.

Warrant for arrest, I2I.

Will, probating, Ir3.

Wisconsin admitted, 12 .

Women, citizens, $9 \mathrm{I}$.

Writs and processes, II4-II5. 


\title{
The Citizen's Library of Economics, Politics, and Sociology
}

UNDER THE GENERAL EDITORSHIP OF

\author{
RICHARD T. ELY, Ph.D., LL.D.
}

Director of the School of Economics, and Political Science and History; Professor of Political Economy at the University of Wisconsin

\section{MONOPOLIES AND TRUSTS}

By Richard T. Ely, Ph.D., LL.D. Half Leather. I2mo. \$r.25

"It is admirable. It is the soundest contribution on the subject that has appeared."

"By all odds the best written of Professor Ely's works."

- Professor JoHN R. COMmons.

- Professor Simon N. PATTEN, University of Pennsylvania.

\section{THE ECONOMICS OF DISTRIBUTION}

By John A. Hobson, author of "The Evolution of Modern Capitalism," etc. Half Morocco. $12 \mathrm{mo}$. \$1.25.

\section{IN PREPARATION FOR EARLY ISSUE ARE}

ESSAYS IN THE MONETARY HISTORY OF THE UNITED STATES

By Charles J. Bullock, Ph.D., Assistant Professor of Political Economy, Williams College.

\section{ECONOMIC CRISES}

By Edward D. Jones, Ph.D., Instructor in Economics and Statistics, University of Wiscousin.

\section{WORLD POLITICS}

By Paul. S. Reinsch, Ph.D., LL.B., Assistant Professor of Political Science, University of Wisconsin.

\section{GOVERNMENT IN SWITZERLAND}

By John Martin Vincent, Ph.D., Associate Professor of History, Johns Hopkins University.

HISTORY OF POLITICAL PARTIES IN THE UNITED STATES

By Jrsse MACy, LL.D., Professor of Political Science in Iowa College.

\section{THE MACMILLAN COMPANY}




\title{
THE AMERICAN COMMONWEALTH.
}

BY THE

\author{
Right Hon. JAMES BRYCE, D.C.L.,
}

Author of "The Holy Roman EMpire"; M.P. fOR AbERdeEN.

\section{Third Edition, Revised Throughout. In Two Volumes.}

Large 12mo. \$4.00, net. Abridged Edition, In one volume, \$1.75, net.

\section{PRESS NOTICES.}

" His work rises at once to an eminent place among studies of great nations and their institutions. It is, so far as America goes, a work unique in scope, spirit, and knowledge. There is nothing like it anywhere extant, nothing that approaches it. . . . Without exaggeration it may be called the most considerable and gratifying tribute that has yet been bestowed upon us by an Englishman, and perhaps by even England herself. . . . One despairs in an attempt to give, in a single newspaper article, an adequate account of a work so infused with knowledge and sparkling with suggestion. ... Every thoughtful American will read it and will long hold in grateful remembrance its author's name." - The New York Times.

"Written with full knowledge by a distinguished Englishman to dispel vulgar prejudices and to help kindred people to understand each other better, Professor Bryce's work is in a sense an embassy of peace, a message of good-will from one nation to another." - The Times, London.

"This work will be invaluable . . . to the American citizen who wishes something more than a superficial knowledge of the political system under which he lives and of the differences between it and those of other countries. . . . The fact is that no writer has ever attempted to present so comprehensive an account of our political system, founded upon such length of observation, enriched with so great a mass of detail, and so thoroughly practical in its character. ... We have here a storehouse of political information regarding America such as no other writer, American or other, has ever provided in one work. . . . It will remain a standard even for the American reader." - New York Tribune.

"The book should be known by every American who wishes to understand his own country. ... I I is by far the most able, sincere, candid, and impartial study of the condition of the United States that has ever appeared since De Tocqueville's memorable work." - Boston Beacon.

THE AMERICAN COMMONWEALTH. Abridged Edition. For the use of Colleges and High Schools. Being an Introduction to the Study of the Government and Institutions of the United States. One Vol. Crown 8vo. \$1.75, net.

\section{THE MACMILLAN COMPANY,}




\section{AN OUTLINE OF POLITICAL HISTORY, I492-I87I.}

BY

\section{GOLDWIN SMITH, D.C.L.}

\section{With Map. Crown 8vo. \$2.00.}

\section{PRESS COMMENTS.}

" Is a literary masterpiece, as readable as a novel, remarkable for its compression without dryness, and its brilliancy without any rhetorical effort or display. What American could, with so broad a grasp and so perfect a style, have rehearsed our political history from Columbus to Grant in 300 duodecimo pages of open type, or would have manifested greater candor in his judgment of men and events in a period of four centuries? It is enough to say that no one before Mr. Smith has attempted the feat, and that he has the field to himself." - The Nation.

"It is a marvel of condensation and lucidity. In no other book is the same field covered so succinctly and so well. Of the five chapters, the first deals with the Colonial epoch, the second with the Revolutionary period, the third and fourth review the history of the Federal Government to the outbreak of the Civil War, and the fifth depicts the era of rupture and reconstruction. We have marked certain passages for extract, but the truth is that alıost every page is enriched with striking comments that cause the reader to carefully reconsider, if not to change, his views of historical persons and events." - New York Sun.

"To say that nothing comparable with this most instructive and enchanting volume has hitherto come from Professor Smith's pen would perhaps be only anticipating the judgment of its readers." - Toronto Mail.

"Professor Goldwin Smith always writes with a trenchant pen, but he has never written anything so incisive in style and so interesting in the points of view taken and the judgment of men and things as his essay of three hundred pages on the United States, the scope of which is well described in its sub-title An Outline of Political History.' This brilliant comment of a liberal Englishman on the history and institutions of this country is of the utmost value to Americans, who will not be repelled by its occasional injustice, but who will be materially helped to a juster conception of the results of Ainerican civilization, and who will be immensely entertained and interested by the vivacity and freshness with which the comment is made." - The Outlook.

"We know nothing on the suhject at all approaching it in brevity, joined to clearness and comploteness, as an essay, nothing where intellectual disinterestedness so dominates all things, none where a happy sentence or a striking phrase so effectually tells a story which many pages in other hands have in vain sought to tell." New York Times.

\section{THE MACMILLAN COMPANY,}

66 FIFTH AVENUE, NEW YORK. 


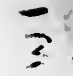




$$
\Delta
$$


